\title{
Estudio de variantes de la apolipoproteína A-I humana involucradas en amiloidosis.
}

\author{
Tesis doctoral \\ Universidad Nacional de La Plata \\ Facultad de Ciencias Exactas \\ Departamento de Ciencias Biológicas \\ - 2013 -
}

Tesista: Lic. Nahuel Ramella

Director: Dra. M. Alejandra Tricerri

Co-director: Dr. Omar J. Rimoldi

Asesor académico: Dra. Laura Bakás. 
El presente trabajo de tesis, para optar al grado de Doctor de la Facultad de Ciencias Exactas de la Universidad Nacional de La Plata, fue realizado en el Instituto de Investigaciones Bioquímicas de La Plata (INIBIOLP), Facultad de Ciencias Médicas, Universidad Nacional de La Plata, bajo la dirección de la Dra. M. Alejandra Tricerri y la co-dirección del Dr. Omar J. Rimoldi. 
La curiosidad se ha metamorfoseado

en una pasión fatal, irresistible.

C. Baudelaire

Para Florián 


\section{Ciencia.}

En algún lugar de los vastos arenales de Marte hay un cristal muy pequeño y muy extraño.

Si alzas el cristal y miras a través de él, verás el hueso detrás de tu ojo, y más adentro luces que se encienden y se apagan, luces enfermas que no consiguen arder, son tus pensamientos. Si oprimes entonces el cristal en el sentido del eje medio, tus pensamientos adquirirán claridad y justeza deslumbrantes, descubrirás de un golpe la clave del Universo todo, sabrás por fin contestar hasta el último porqué.

En algún lugar de Marte se halla ese cristal.

Para encontrarlo hay que examinar grano por grano los inacabables arenales. Sabemos, también, que, cuando lo encontremos y tratemos de recogerlo, el cristal se disgregará, sólo nos quedará un poco de polvo entre los dedos. Sabemos todo eso, pero lo buscamos igual.

H.G. Oesterheld 


\section{Agradecimientos.}

Principalmente a Alejandra, mi directora, que sin dudarlo me dio la oportunidad de realizar este doctorado y en todo momento acompañó mi trabajo. A Omar que codirigió esta tesis y contribuyó con trabajo e ideas claras. Al grupo de trabajo que se fue formando en torno a este proyecto: Tati, Guillermo, Gabriela, Soledad y Silvana.

AI INIBIOLP, lugar donde siempre encontré puertas abiertas y buena predisposición. Resulta ingrato de mi parte no nombrar a todos aquellos que molesté en reiteradas oportunidades y me ayudaron de buena gana, pero los recuerdo claramente (y seguramente ustedes también lo recuerdan así que bien se pueden dar por aludidos). Para compensar ahí les va un gracias doble.

A las instituciones que hicieron posible este doctorado: la Universidad Nacional de La Plata y el Conicet.

A la familia que siempre empuja, mi viejo, mi vieja y mi hermano, pero también a mis primos, primas, tíos y tías con los que tanto comparto.

A María José por aguantarme.

A mis amigos, Luciano C, Luciano S., Sebastián, Pedro, Bruno, Quico, Manuel, Leandro, Juan Lancia, Andres, Nico R., Mariano, Nico H., Toncho, Noelia, Martina, Sol, Diego (Jaque), Pablo Guzzo.

N.R. 

ABCA-1
ATP binding cassette 1
AFM
Microscopio de fuerza atómica
apoA-I
Apolipoproteína A-I
bis-ANS
Ácido 4,4'-Dianilino-1,1'-Binaftil-5,5'-Disulfonico
DCFH-DA
2',7'-diclorofluorscein-diacetate
GAGs
Glicosaminoglicanos
$\mathrm{HClO}$
Anión hipoclorito
$\mathrm{HDL}$
Lipoproteínas de alta densidad
ICAM-1
Moléculas de adhesión intercelulares
IL-1
Interleuquina 1
IPTG
Isopropil tio galactósido
MMP-12
Metaloproteasa de matriz 12
MTT
Bromuro de 3-(4,5-dimetiltiazolil)-2,5-difenil-tetrazolio
ndHDL
Lipoproteínas de alta densidad nacientes discoidales
ON
Over night (toda la noche)
$\mathrm{pl}$
Punto isoeléctrico
PMN
Células polimorfo nucleares
ROS
Especies reactivas de oxígeno
TCR
Transporte reverso de colesterol
TEM
Microscopio electrónico de trasmisión
ThT
Tioflavina - T
TNF-a
Factor de necrosis tumoral a
TPA
12-O-tetradecanoil-forbol-13-acetato
VCAM-1
Moléculas de adhesión vascular 


\section{Índice.}

1. Introducción 9

1.1. Amiloidosis 9

1.2. Apolipoproteína A-I. Estructura y función. 11

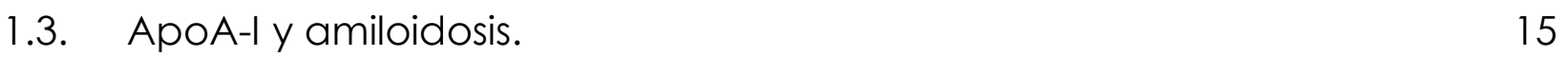

$\begin{array}{ll}\text { 1.4. Inflamación, aterosclerosis y amiloidosis. } & 17\end{array}$

2. Hipótesis 22

$\begin{array}{ll}\text { 3. Objetivos } & 23\end{array}$

4. Materiales y métodos $\quad 24$

4.1. Clonado, mutagénesis y transformación. 24

4.2. Expresión y purificación. 25

4.3. Ensayos de fluorescencia. 26

4.4. Agregación de proteínas seguida por fluorescencia de ThT. 31

4.5. Unión a heparina determinada por dispersión de luz (light scattering) 32 y unión ThT.

4.6. Procesamiento pro-inflamatorio de las variantes de apoA-I. 33

4.7. Remoción de colesterol. $\quad 34$

4.8. Microscopía (TEM y AFM) 35

4.9. Activación de macrófagos murinos. 36

4.10. Protocolos generales de trabajo. 37

4.11. Análisis estadístico. 39

5. Resultados I: Implicancia de la apolipoproteína A-I wild type humana 40 en amiloidosis.

5.1. Efecto del pH sobre el plegamiento y la estabilidad de apoA-l. 40

5.2. Unión de Tioflavina-T y análisis de los agregados de apoAl. 43 
5.3. Agregación inducida por unión a heparina.

5.4. Influencia de modificaciones proteolíticas y oxidativas sobre apoA-I 49 respecto del plegamiento de la proteína.

6. Resultados II: Estudios estructurales y biológicos de las variantes de la 55 apolipoproteína A-I Gly26Arg y Lys 107-0 implicadas en amiloidosis.

6.1. Diferencias conformacionales entre apoA-I wt y las mutantes Gly26Arg y Lys 107-0.

6.2. Estabilidad y plegamiento de las variantes de apoA-I en estudio.

6.3. Caracterización morfológica de los agregados.

6.4. Influencia del ambiente pro-inflamatorio sobre el plegamiento de las 64 variantes de apoA-I Gly26Arg y Lys 107-0.

6.5. Activación de macrófagos por las variantes amiloidogénicas de apoA-I.

7. Discusión.

7.1. Influencia del pH sobre la estabilidad y agregación de apoA-I wt.

7.2. ApoA-I wt y unión a heparina.

7.3. Estabilidad y agregación de las variantes apoA-I Gly26Arg y apoA-I 71 Lys 107-0.

7.4. Efectos del microambiente inflamatorio sobre la integridad y agregación de apoA-I wt, Gly26Arg y Lys 107-0.

7.5. Activación de macrófagos por las variantes de apoA-I.

8. Conclusiones.

9. Modelo y perspectivas.

10. Bibliografía. 


\section{Introducción.}

\subsection{Amiloidosis.}

Ciertas proteínas requieren un alto grado de flexibilidad conformacional para llevar a cabo sus funciones biológicas. Estas proteínas están expuestas por otro lado a un alto riesgo de alteración en el sutil equilibrio entre una sofisticada función biológica y la tendencia a la auto agregación (Merlini y Bellotti, 2003). Las amiloidosis constituyen así un grupo de enfermedades caracterizadas por la conversión de la estructura nativa de ciertas proteínas en una conformación mal plegada que se da generalmente con ganancia de estructura de hoja- $B$, produciendo su agregación y depósito, lo que lleva al daño tisular, mal funcionamiento de los órganos, y en algunos casos conduce a la muerte (Rambaran y Serpell, 2008; Ferreira y col., 2007). La razón por la cual estos agregados proteicos son tóxicos no es completamente conocida. El simple mecanismo de reemplazo del tejido por depósitos amiloides parece insuficiente para explicar la toxicidad de estas proteínas. En particular en la última década, un campo de investigación creciente ha implicado a los agregados de tipo oligómeros (más que a estructuras fibrilares) como especies citotóxicas en la enfermedad de Alzheimer (Lambert y col., 1998) y en la amiloidosis debida a transtirretina (Reixach y col., 2004).

El plegamiento de un polipéptido recién sintetizado ocurre siguiendo una rápida secuencia de conformaciones en el citoplasma (Merlini y Bellotti, 2003). De acuerdo con la "Teoría del perfil energético del plegamiento de proteínas" (The folding energy landscape theory of protein folding) este proceso se asemeja a un embudo en el cual las conformaciones intermedias devienen progresivamente en la formación de complejos más estables hasta formar la especie final. No obstante puede ocurrir que el polipéptido adquiera un estado mal plegado alternativo y relativamente estable, el cual es propenso a la agregación (Merlini y Bellotti, 2003; Onuchic y col., 1997). Este proceso es esquematizado en la Figura 1.1. 
Figura 1.1. Panorama energético del plegamiento de proteínas. El polipéptido recién sintetizado y totalmente desplegado sigue un camino tipo embudo en el cual los intermediarios conformacionales se vuelven progresivamente más organizados, resultando en el estado nativo que es la especie más estable.

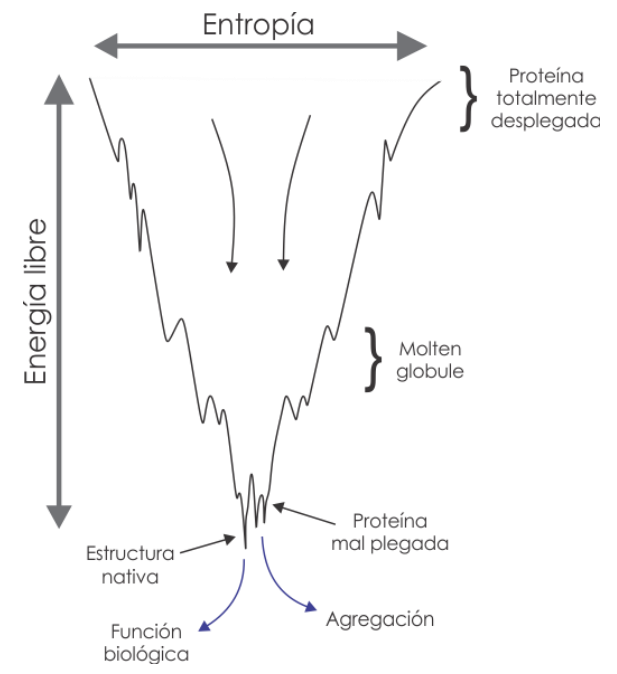

El porqué las proteínas potencialmente amiloidogénicas se agregan se debe a distintas razones según el caso y es motivo de un amplio campo de investigación. Ciertas proteínas tienen una conformación intrínseca que es propensa a la agregación, la cual se incrementa con el envejecimiento, o también con un aumento persistente de la concentración, como ocurre con la transtirretina (Saraiva, 2001). Otro mecanismo propuesto es el reemplazo de un aminoácido que da lugar a una variante patológica, que induce en consecuencia amiloidosis hereditarias. En algunos de ellas la patogenicidad parece estar asociada a una disminución de la estabilidad estructural de la variante mutante, como es el caso de L55P para transtirretina (Quintas y col., 2001) y Asp67His para la lisozima (Canet y col., 1999). Un tercer mecanismo es el remodelado proteolítico de una proteína precursora que genera fragmentos amiloidogénicos. Ejemplo de este último caso es el APP (proteína precursora de amiloide), una proteína del sistema nervioso central, la cual por acción de proteasas genera un péptido de 40-42 aminoácidos (Hardy, 2002). Este péptido, conocido como péptido-A $A$, es muy proclive a formar oligómeros y fibras amiloides insolubles, y es uno de los responsables de la enfermedad de Alzheimer (Roychaudhuri y col., 2009; O'Brien y Wong, 2011). Además de los mecanismos mencionados, otros factores asociados al microambiente celular, como la concentración local de metabolitos o "crowding", o la unión a glicosaminoglicanos presentes en la matriz extracelular, el cambio de pH, etc. 
pueden influir en la agregación o incrementar el potencial amiloidogénico de esas proteínas (Merlini y Bellotti, 2003).

Las amiloidosis difieren en el tipo de proteína precursora que sufre el plegamiento anómalo, el órgano diana involucrado en los depósitos $y$, consecuentemente en el desarrollo de la clínica asociada a la patología. Al momento más de 20 proteínas fueron identificadas induciendo amiloidosis de distinto tipo, yendo desde amiloidosis cerebral localizada, como en la enfermedad de Alzheimer y la enfermedad de Creutzfeldt-Jakob, hasta amiloidosis sistémicas tales como la inducida por las cadenas livianas de inmunoglobulinas (Ig) y por la transtirretina. De manera interesante, más allá de la flexibilidad conformacional mencionada no se ha encontrado secuencias o motivos estructurales compartidos entre dichas proteínas,

\subsection{Apolipoproteína A-I. Estructura y función.}

La apoliproteína A-I humana (apoA-I) es una proteína de aproximadamente 28 kDa, la cual es sintetizada principalmente en el hígado y, en menor grado, en el intestino. Es el mayor constituyente proteico en las lipoproteínas de alta densidad (HDL). La proteína madura consta de 243 aminoácidos codificados en el exón 3 (143) y 4 (44-243). Inicialmente la secuencia de aminoácidos cuenta con un pre-propéptido de 24 residuos. Una vez que el péptido señal de 18 aminoácidos es clivado, la proteína es secretada al plasma donde, por la acción de metaloproteasas, se remueven los 6 residuos restantes para dar lugar a la proteína madura (Obici y col., 2006).

Estructuralmente la apoA-I fue definida como una proteína en estado de glóbulo fundido (molten globule) en condiciones fisiológicas, en base a poseer una estructura secundaria bien definida pero estructura terciaria relativamente laxa. Los análisis de desnaturalización térmica y química permitieron estimar una variación de energía libre de desnaturalización $\left(\Delta \mathrm{G}^{\circ}\right)$ aproximado de $2,4 \mathrm{Kcal} / \mathrm{mol}$, (mientras que para las proteínas globulares ésta se ubica entre 5 y $15 \mathrm{Kcal} / \mathrm{mol}$ ). Además las interacciones terciarias que estabilizan las a-hélices son muy débiles, dando lugar a una elevada plasticidad conformacional lo cual permite a esta 
proteína adoptar distintas conformaciones al momento de interactuar con sus distintos ligandos (Gursky y Atkinson, 1996; Obici y col., 2006).

En estado libre de lípidos, el $\sim 60 \%$ de la estructura secundaria de la apoA-I está organizada en a-hélices anfipáticas (conteniendo una cara polar y una cara no polar más expuesta o protegida del solvente respectivamente), mientras que la región N-terminal está compuesta por secuencias de aminoácidos que determinan regiones cortas con estructura de hoja- $\beta$ y otras desorganizadas. Las principales clases de hélice identificada en apoA-I son las del tipo A, de 22 aminoácidos cada una, interrumpidas en general por residuos de Pro y caracterizadas por la presencia de residuos básicos cerca de la superficie hidrofóbica/hidrofílica y residuos ácidos en el centro de la cara polar; una hélice de tipo $\mathrm{G}$ es predicha en el extremo $\mathrm{N}$, con una distribución anárquica de residuos positivos y negativos en la cara polar; finalmente, hélices de clase $Y$, caracterizadas por la presencia de tres clusters de residuos básicos en la cara polar. Las hélices de clase A se encuentran en las regiones 44-65, 66-87, 121-142, 143-164, 165-186 y 187-208, las de clase $G$ en el segmento $8-33$, y las de clase $Y$ en la región 88-98, 99-120, 209-219 y 220-241 (Fig. 1.2)(Obici y col., 2006; Segrest y col., 1992).

Numerosos estudios intentan explicar la conformación adoptada por 2 moléculas de apoA-I al interactuar con lípidos para formar los complejos de HDL discoidales nacientes (ndHDL) (ver más abajo). En la actualidad existe gran consenso apoyando un modelo donde las hélices anfipáticas se disponen en forma de "cinturón" alrededor de una bicapa lipídica en donde el eje longitudinal de las hélices de ambas proteínas se ubica perpendicular a las cadenas acílicas de los ácidos grasos de los fosfolípidos, y el fragmento $\mathrm{N}$-terminal se pliega en forma de horquilla para maximizar la interacción con el dominio C-terminal (Fig. 1.2) (Davidson y Thompson, 2007; Tricerri y col., 2001).

Respecto de la estructura terciaria, la flexibilidad conformacional mencionada ha dificultado la obtención de una estructura cristalina de la proteína con la secuencia completa. Borhani y colaboradores reportaron la estructura cristalina de una variante truncada de apoA-l carente de los primeros 43 
aminoácidos (4(1-43)apoA-I) (Borhani y col., 1997). Esta variante revela una estructura a-helicoidal con una disposición lineal interrumpida periódicamente por torceduras forzadas por la presencia de prolinas, las cuales constriñen a la proteína a doblarse adoptando una forma curvada (Fig. 1.2.A). Esta podría ser la explicación de la plasticidad conformacional que muestra apoA-I. Dos moléculas de $\Delta$ (1-43)apoA-I se asocian una con otra en disposición antiparalela para generar un dímero de forma elíptica. Esta unidad dimérica es considerada el estado conformacional en que se encuentra la proteína en condiciones biológicas. Dos de estos dímeros pueden ensamblarse para formar un anillo tetramérico elíptico (Borhani y col., 1997) (Fig. 1.2.C). Más recientemente fue publicada una estructura cristalina de la apoA-I pero en este caso truncada en el C-terminal $(\Delta(185-243))$ (Mei y Atkinson, 2011). Esta estructura también sugiere un monómero altamente flexible (Fig. 1.2.B), y un dímero proteico compuesto por dos moléculas antiparalelas adoptando una conformación semicircular con $\sim 80 \%$ de a-hélice (Fig. 1.2.D). Este arreglo propuesto explica por tanto la conformación de la proteína libre de lípidos y la formación de las partículas ndHDL de manera muy similar a lo que lo hace la estructura cristalina N-terminal de Borhani (Mei y David Atkinson, 2011).

Figura 1.2. Representación de dos posibles estructura tridimensionales que podría asumir apoA-I. A y C) Estructura propuesta por Borhani y col. (1997) de $\Delta$ (1-43)apoA-I en forma de monómero (A) y dímero (C). B y D) Estructura propuesta por Mei y Atkinson (2011) de $\Delta(185-$ 243)apoA-I en forma de monómero (B) y dímero (D).

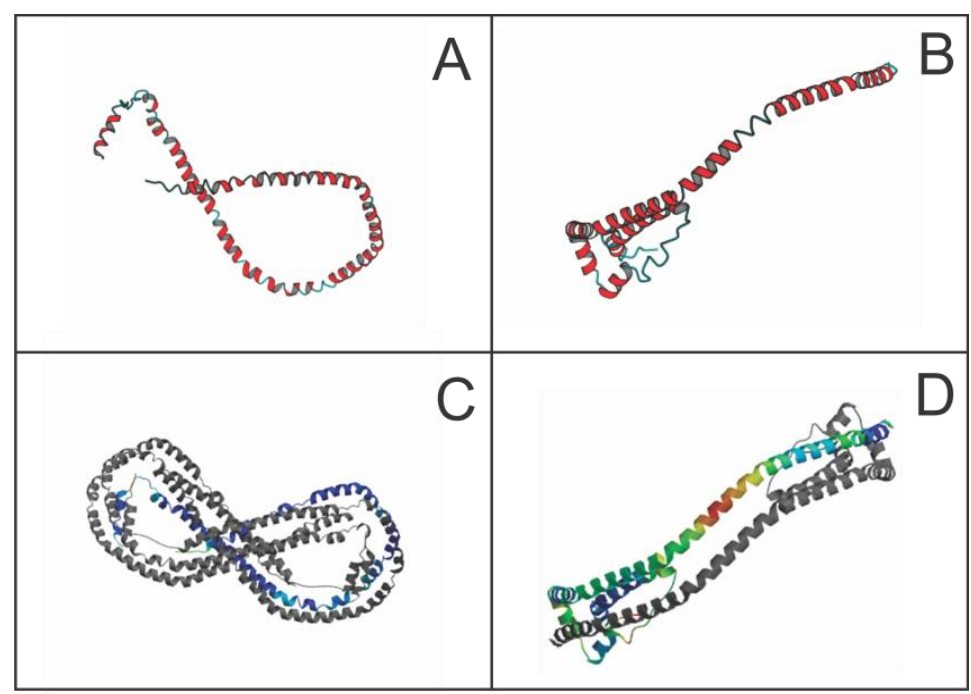


En términos funcionales, apoA-I en circulación se encuentra en su mayoría formando parte de las HDL jugando un rol preponderante en el transporte reverso de colesterol (TRC). La proteína se secreta en forma libre de lípidos o muy poco lipidada. Esta conformación es la óptima para interactuar con membranas celulares, donde activa al transportador ATP binding cassette 1 (ABCA1), favoreciendo la remoción de colesterol y fosfolípidos y dando lugar a la formación de las ndHDL. Este proceso de remoción es complejo y varios de los pasos metabólicos son sugeridos de ser activados por apoA-l: 1) el transporte de colesterol intracelular hacia estructuras de la membrana denominados caveolas mediante la estimulación de caveolina, 2) la movilización de pooles internos de colesterol, mediado por la estimulación del $A B C A 1,3$ l) la activación de proteína quinasa $C$ (PKC) por apoA-I involucrada en la inhibición de la esterificación de colesterol intracelular via la Acil Colesterol Acil transferasa (Yamauchi y col., 2004). Este proceso es especialmente importante en la remoción de colesterol de macrófagos y fibroblastos presentes en los espacios subendoteliales. El colesterol externalizado es luego esterificado por acción de la lecitin:colesterol aciltransferasa (LCAT), activada por un dominio formado por las hélices 6 y 7 de la apoA-l; las partículas resultan así enriquecidas con ésteres de colesterol y se vuelven mas grandes y complejas al translocar otros lípidos con otras lipoproteínas, dando lugar a las HDL maduras (Ohashi y col., 2005). La interacción de la apoA-I en estas HDL con el receptor SR-BI ("scavenger o basurero") clase B tipo I media el flujo de los ésteres de colesterol al hígado sin que esto implique la degradación de las HDL.

En circulación entre el 5 y 10\% de la apoA-I se encuentra en estados libre de lípidos. El origen de esta fracción proteica se debe a moléculas de apoA-I que no se unen a lípidos cuando son secretadas y, también, a que algunas moléculas de apoA-I se disocian de las HDL en circulación (Davidson y Thompson, 2007). Algunos trabajos destacan la importancia de la proteína libre de lípidos puesto que es en este estado cuando se da la mayor interacción con el ABCAl (Zannis y col., 2006). 


\subsection{ApoA-I y amiloidosis.}

Se han reportado aproximadamente 50 variantes naturales de apoA-I de las cuales, al menos la mitad están asociadas con bajos niveles de HDL en circulación (Obici y col., 2006), y 13 (aunque el número varía con la bibliografía) fueron descriptas induciendo amiloidosis de distinta severidad (Invernizzi y col., 2012). La mayoría de las mutantes reportadas como amiloidogénicas implican la sustitución de un aminoácido aunque también se han reportado mutantes con deleción de uno o más residuos. Muchas de las sustituciones se dan con ganancia de un aminoácido polar con carga positiva, generalmente arginina, lo que sugiere que la presencia de una carga extra podría resultar en un rol patogénico (Obici y col., 2006). No obstante hay variantes que no se dan con ganancia de una carga positiva extra pero si con la pérdida de un residuo hidrofóbico. Otro patrón frecuente es que muchas variantes ganan un residuo de prolina el cual cabe considerar por su carácter disruptor de estructuras a-hélice. Un componente frecuente en las lesiones amiloides donde se encuentra involucrada apoA-l, es un péptido que corresponde al fragmento $\mathrm{N}$-terminal de la proteína de aproximadamente 9 -11 kDa. Generalmente en las lesiones cardíacas este péptido abarca hasta el residuo 93 (apoA-I 1-93), mientras que en otros órganos se encuentran fragmentos 1-80 hasta 1-100 (Adachi y col., 2012). La presencia de estos fragmentos se debería principalmente a la actividad de diversas proteasas que se encuentran particularmente activas en las zonas de la lesión, posiblemente como repuesta a un estímulo inflamatorio. Ocurre, también, que la proteína libre es más susceptible a la proteólisis que cuando esta acomplejada con lípidos (Mucchiano y col., 2001; Obici y col., 2006).

En base al hallazgo del péptido N-terminal en las lesiones, sería esperable que esta región de la proteína presentara la mutación pro-amiloidogénica. Sin embargo, si bien gran parte de las mutaciones descriptas se encuentran entre los aminoácidos 50 y 93, Erickson y colaboradores identifican como "hot spot" otra región comprendida en la región 170-178 por la alta frecuencia de variantes involucrando esa zona (Eriksson y col., 2009). Incluso otras sustituciones (como las estudiadas en este trabajo) son descriptas fuera de estas regiones. En la figura 1.3 
se muestran algunas de las mutaciones mencionadas detectadas en pacientes con amiloidosis inducidas por apoA-I.

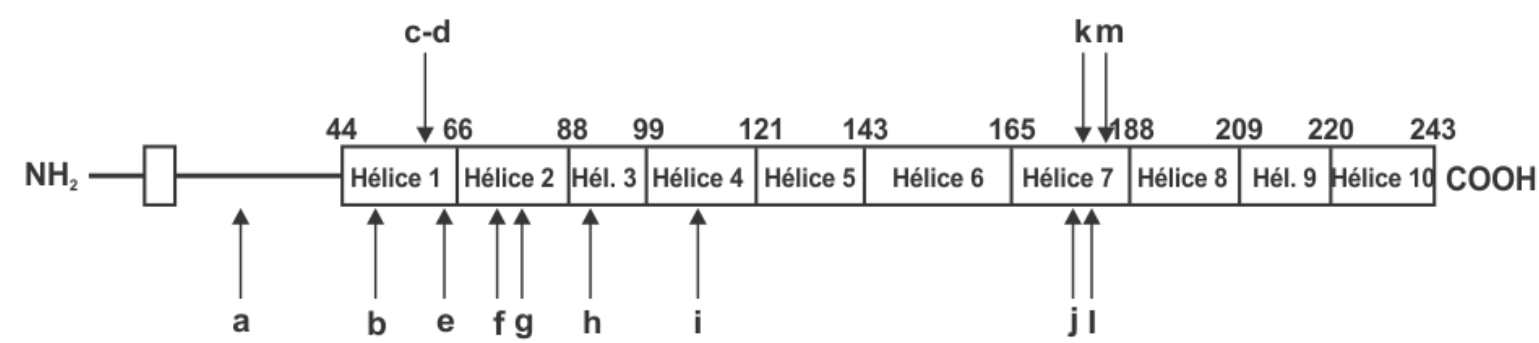

\begin{tabular}{|l|l|l|l|l|}
\hline a. Gly26Arg & b. Trp50Arg & c. Leu60Arg & d. Leu60-Trp72 del. & e. Leu64Pro \\
\hline f. Glu70-Trp72 del. & g. Leu75Pro & h. Leu90Pro & i. Lys107 del. & j. Arg173Pro \\
\hline k. Leu174Ser & I. Ala175Pro & m. Leu178His & & \\
\hline
\end{tabular}

Figura 1.3. Variantes naturales de apoA-I involucradas en amiloidosis. Esquema modificado de Matsunaga y Col., 2010.

Muchas mutaciones de apoA-I están asociadas con depósitos de fibras amiloides predominantemente en hígado, riñones y corazón, y en menor frecuencia en piel, testículos, laringe y nervios periféricos. Con cierta asiduidad, se observa, postmortem, un extenso depósito visceral de material amiloide, y en muchos casos con evidente insuficiencia renal (Matsunaga y col., 2010). Si bien la penetrancia de las mutaciones de apoA-l asociadas a amiloidosis es alta, los depósitos se desarrollan durante décadas antes de que los síntomas se hagan evidentes. Las variantes Gly26Arg y Lys107-0 son de particular interés en nuestro caso y fueron seleccionadas para ser estudiadas en el desarrollo de esta tesis. Ambas son propensas a formar estructuras amiloides, sin embargo la localización de los depósitos difiere significativamente una de otra. El primer caso, que involucra una ganancia de carga positiva, se caracteriza por afectar hígado, riñones, y el tracto gastrointestinal (Planté-Bordeneuve y Said, 2011). Con frecuencia se encuentra en los depósitos de fibras generados por la variante Gly26Arg un fragmento que corresponde a los primeros 83 aminoácidos de la proteína (Lagerstedt y col., 2007). En el segundo caso, la variante Lys107-0, que involucra una pérdida de carga positiva (una deleción del residuo de lisina en posición 107), se da con un gran depósito de fibras en la íntima de vasos 
sanguíneos, la cual está estrechamente relacionada con la generación de arterosclerosis severa (Mucchiano y col., 2001).

Además de las mutaciones mencionadas, apoA-I también está involucrada en amiloidosis del tipo no hereditaria. Se ha reportado (por inmunohistoquímica y tinciones con rojo congo) la presencia de depósitos amiloides de la proteína wt asociadas a placas ateroscleróticas seniles (Westermark y col., 1995). Este hallazgo sugiere la posibilidad de que los microambientes relacionados con las lesiones ateroscleróticas puedan afectar su conformación e inducir su agregación.

Es interesante resaltar, que a pesar de las numerosas variantes de apoA-I detectadas induciendo amiloidosis, todas son descriptas en países desarrollados, por lo que es de suponer y esperar que con la implementación futura de estudios genéticos se identifiquen nuevas variantes patológicas de esta proteína en nuestro medio.

\subsection{Inflamación, aterosclerosis y amiloidosis.}

La inflamación es la repuesta a un proceso infeccioso o a la injuria de tejidos que involucra el reclutamiento y activación de células del sistema inmune. La inflamación tiene una respuesta vascular, la cual depende principalmente de las células endoteliales (monocapa de células confluentes que tapizan los capilares sanguíneos), y una repuesta celular que involucra células del sistema inmune como lo son neutrófilos y macrófagos entre otras varias. Las células endoteliales normalmente se encuentran arrestadas, pero ante señales pro-inflamatorias son activadas y experimentan cambios fenotípicos significativos. La activación puede ser mediada por un receptor de membrana asociado a proteína $G$ o puede deberse a la presencia de citoquinas pro-inflamatorias como TNF-a e IL-1. Como resultado, la activación del endotelio conduce a un aumento del flujo sanguíneo, reclutamiento de neutrófilos y macrófagos mediado por la expresión de agentes quimioatrayentes y proteínas de adhesión como lo son selectinas, integrinas, VCAM-1 e ICAM-1, y se incrementa la permeabilidad del endotelio lo que genera la migración de las células del sistema inmune hacia los tejidos extravasculares (Pober y Sessa, 2007; Onat y col., 2011). En este contexto los neutrófilos juegan un 
rol fundamental puesto que responden rápidamente a la presencia de antígenos o señales inflamatorias. Cuando los neutrófilos son activados sintetizan IL-1, IL-6, IL-12, TGF- $\beta$ (factor de crecimiento transformante $\beta$ ) y TNF-a, las que actúan activando otros neutrófilos y otras células del sistema inmune. Durante la activación estas células experimentan un estallido oxidativo que genera la producción de $\mathrm{ROS}\left(\mathrm{O}_{2}{ }^{2}\right.$, $\mathrm{HO}$, ${ }^{\prime} \mathrm{O}_{2}, \mathrm{H}_{2} \mathrm{O}_{2}$ ) por acción de la $\mathrm{NADH}$ oxidasa, y $\mathrm{HClO}$ por la vía de la mieloperoxidasa. La activación también promueve la liberación de granulocitos que portan una gran variedad de proteasas (elastasa, colagenasa, gelatinasa) que resultan en una elevada actividad proteolítica tanto para el antígeno como para el entorno (Wright y col., 2010). Por su parte, un número reducido de macrófagos se encuentra constantemente presente en los distintos tejidos y responden a la presencia de antígenos o injurias sintetizando citoquinas proinflamatorias (TNF-a e IL-1) y por lo tanto disparando el proceso inflamatorio. No obstante cuando el proceso inflamatorio ya está en marcha, son reclutados por las células endoteliales, en forma de monocitos, y migran hacia el tejido extravascular donde, por acción del INF-Y (interferón gama), se diferencian y adquieren su forma de macrófago y contribuyen con el proceso inflamatorio sintetizando citoquinas y agentes quimioatrayentes, factores de crecimiento y liberando proteasas (Robins y Cotran, 2005; Shi y Pamer, 2011). En resumen, los tres tipos celulares mencionados, cada uno por separado y ante estímulos comunes o específicos, son capaces de disparar las señales que dan lugar a un proceso inflamatorio. Otra característica del proceso inflamatorio es la apoptosis asociada a células endoteliales, algunos lípidos y citoquinas inflamatorias son fuertes inductores de esta vía de muerte celular (O'Connell y Genest, 2001).

La aterosclerosis es un proceso que da lugar al estrechamiento o la oclusión completa de la luz arterial y está altamente relacionada al proceso inflamatorio. El fenómeno previo a la aterosclerosis es el daño del endotelio, ya que desencadena el reclutamiento de células inflamatorias y de lípidos (en especial colesterol) un proceso complejo y donde ambos factores se retroalimentan (González Hernandez, 2010). Las LDL son las lipoproteínas involucradas en el aporte de colesterol hacia células de tejidos periféricos, siendo internalizadas al ser 
reconocida la apoB 100 por los receptores específicos de membrana. El contenido de colesterol celular está altamente regulado para evitar su acumulación. Así un exceso de colesterol celular inhibe entre otros pasos su propia síntesis de novo y la captación desde las LDL circulantes. Mientras las LDL circulan en plasma están protegidas de la oxidación por numerosos antioxidantes incluyendo enzimas y vitaminas. Sin embargo, ante el daño endotelial estas lipoproteínas pueden llegar a la íntima donde dicha protección desaparece. En este caso la apoB100 oxidada es reconocida por los receptores scavenger que no están regulados. Como resultado los macrófagos (reclutados ante la lesión hacia el espacio subendotelial) se sobrecargan de lípidos almacenándolos en vesículas endocíticas y dando lugar a las denominadas células espumosas. Ante la muerte de estas células se liberan los lípidos, que forman depósitos dentro de la íntima. Estos depósitos se transforman en los centros de la placa aterosclerótica madura. Las células musculares que migran dentro de la íntima sintetizan matriz colagenosa que cubre la acumulación de lípidos formando un "capuchón fibroso". Este capuchón contiene además macrófagos activos, que a medida que la lesión avanza segregan MMPs degradantes de la matriz y que puede resultar en el desprendimiento de la placa. Como se resume de lo anterior, la inflamación desempeña un rol fundamental en la aterogénesis. Normalmente esta respuesta se inicia por un antígeno o por un traumatismo. Curiosamente hasta la fecha no se ha identificado ningún antígeno específico capaz de iniciar este proceso. Podría existir una similitud molecular entre este(os) posible(s) antígeno(s) y los patógenos exógenos. El (los) posibles antígenos podrían ser agentes infecciosos o moléculas modificadas generadas por ROS. (Baynes y Dominiczak, 2011). El proceso finaliza cuando se remueve el estímulo y se recompone la arquitectura tisular. Si el estímulo no es eliminado el proceso inflamatorio persiste y evoluciona, inclusive puede convertirse en un escenario crónico.

Las HDL asumen un rol como agente anti-aterogénico, extensiva investigación estadística reporta que la concentración de HDL es inversamente proporcional al riesgo ateroesclerótico. Esto se debe (y se atribuyó durante mucho tiempo) a su habilidad para promover la remoción de colesterol desde las células 
como fue mencionado más arriba. No obstante, las HDL también cumplen funciones como anti-oxidantes, anti-inflamatorias y anti-trombóticas que no son menos importantes. El rol anti-inflamatorio de las HDL involucra limitar la peroxidación de lípidos, influenciar la expresión de citoquinas, modular el reclutamiento y adhesión de monocitos, y modificar otros aspectos de la función endotelial (Ansell y col., 2005). Ha sido demostrado que las LDL oxidadas inducen daño endotelial. La apoB100 (proteína mayoritaria de las LDL) oxidada se una a la matriz extracelular aumentando la retención de las mismas en la pared vascular. Los fosfolípidos oxidados contenidos en esta lipoproteína serían los principales inductores de inflamación. Las HDL contrarrestan este proceso, supuestamente previniendo la transferencia de lisofosfolípidos desde las LDL oxidadas a las células endoteliales (O'Connell y Genest, 2001).

Paradójicamente las HDL también pueden ser partículas pro-inflamatorias y pro-aterogénicas. La evidencia muestra que en muchos procesos asociados con respuesta inflamatoria como pueden ser infecciones, síndrome metabólico y enfermedades cardiovasculares, se caracterizan por presentar HDL disfuncionales y pro-inflamatorias. Se ha visto que la enzima mieloperoxidasa, muy activa durante el proceso inflamatorio, es capaz de modificar selectivamente las tirosinas presentes en la apoA-I generando nitrotirosinas y clorotirosinas. Como consecuencia, las HDL no pueden llevar a cabo el TRC mediado por ABCAl y los macrófagos asociados con las lesiones ateroscleróticas acumulan más colesterol que lo normal. Esto resulta en una lesión rica en lípidos y por lo tanto más vulnerable a la ruptura y a generar trombosis (Fogelman, 2004).

Por todo lo expuesto, consideramos que distintos procesos celulares (en particular los asociados a inflamación) pueden interactuar definiendo la relación estructura-función-citotoxicidad de una proteína. A pesar de la identificación de la patología en pacientes, muy poco se sabe respecto a los procesos microambientales que puedan alterar este delicado equilibrio de una estructura fisiológica en otra no funcional o incluso citotóxica. Cabe mencionar además que si bien la mayor parte de la apoA-I circula unida a lípidos formando parte de las $\mathrm{HDL}$, estudios previos indican que la proteína libre, generada por catabolismo de 
estas lipoproteínas es más inestable y susceptible de modificaciones estructurales (Safi y col., 2001). El aumento de concentración de proteína libre en lesiones ateroscleróticas avalan este hecho (Curtiss y col., 2006).

El hallazgo de variantes de apoA-I en forma de agregados de tipo amiloide en variados órganos y con distinta severidad abre las siguientes posibilidades:

1) la presencia de un escenario pro-inflamatorio crónico (por ejemplo asociado a aterosclerosis existente) favorece un procesamiento anómalo de la proteína, la que se vuelve patológica y sufre pérdida de sus funciones biológicas.

2) la apoA-I con secuencia mutada posee conformación anómala que induce daño celular y es por sí misma pro-amiloidogénica y citotóxica.

3) una posibilidad combinada, en la que agregados anómalos de la proteína puedan inducir activación de respuesta pro-inflamatoria que perpetúa el cuadro existente. 


\section{Hipótesis de trabajo.}

I. La sustitución de la Gly en posición 26 por una Arg introduce cambios estructurales significativos y resulta en una conformación menos estable.

II. La deleción de la Lys en posición 107 introduce cambios estructurales significativos y resulta en una conformación menos estable.

III. Modificaciones del microambiente afectan la estabilidad de apoA-I wild type y las variantes Gly26Arg y Lys107-0 conduciendo a la formación de agregados tipo amiloides.

IV. Reacciones características del proceso inflamatorio generan un procesamiento pro-amilodogénico en las variantes de apoA-l.

V. Las mutantes de apoA-I Gly26Arg y Lys107-0 son capaces de activar macrófagos e inducir una respuesta inflamatoria. 


\section{Objetivo general.}

Indagar sobre las modificaciones estructurales que experimenta la apolipoproteína A-I humana, tanto la variante wild type como dos mutantes puntuales (Gly26Arg, Lys 107-0), que conllevan a plegamientos del tipo amiloides.

\section{Objetivos específicos:}

I. Estudiar el efecto que ejercen los distintos $\mathrm{pH}$ en la estabilidad, plegamiento y unión a ligando de apoA-I wild type y su relación con la formación de estructuras del tipo amiloides.

II. Caracterizar estructuralmente, empleando técnicas de fluorescencia, a las mutantes amiloidogénicas apoA-I Gly26Arg y apoA-I Lys107-0 respecto de la proteína wild type.

III. Indagar sobre el efecto que tienen los ambientes inflamatorios sobre el procesamiento patológico de la proteína apoA-I wt y las variantes apoA-I Gly26Arg y apoA-I Lys107-0.

IV. Estudiar si las variantes amiloidogénicas en cuestión son capaces de inducir una respuesta del tipo inflamatoria en macrófagos. 


\section{Materiales y Métodos.}

4.1. Clonado, mutagénesis y transformación.

El cDNA correspondiente a la apoA-I humana con la secuencia nativa, el cual fue gentilmente cedido por la Dra. A. Jonas (University of Illinois at UrbanaChampaign, IL), se encuentra clonado en el vector de expresión pET 30a(+) (Novagen, Madison, WI). Este vector posee un gen de resistencia a kanamicina y un promotor inducible por IPTG. Empleando el kit de mutagénesis dirigida (Stratagen, La Jolla, CA) se sustituyó el segundo amino ácido (ácido glutámico) por ácido aspártico a fin de introducir un sitio Asp-Pro lábil para proteólisis mediante ácido fórmico entre los aminoácidos 2 y 3 de la apoA-I (Ryan y col., 2003). Este procedimiento permitió el clivaje de manera eficiente y específica entre la proteína y el péptido de fusión His-tag ubicado en el extremo N-terminal. Los primers utilizados son complementarios, a continuación se detalla la secuencia del primer sense: 5'- GGCAGCAAGATGATCCCCCCCAGAGCCCC-3'. Posteriormente esta construcción se utilizó para generar la mutante apoA-I Gly26Arg empleando nuevamente el kit Quick Change, la secuencia del primer sense es: 5'-GGATGTGCTCAAAGACAGCCGCAGAGACTATGTGTCCC-3'. EI CDNA para la mutante apoA-I Lys-107-0 también fue cedido por la Dra. A. Jonas y se encuentra clonado en el mismo sistema de expresión en el que está el gen para la proteína wt, introduciendo de igual manera el sitio de proteólisis por ácido fórmico. En todos los casos el programa para realizar la PCR fue:

\begin{tabular}{|c|c|c|}
\hline Ciclos & Temperatura $\left({ }^{\circ} \mathrm{C}\right)$ & Tiempo $(\mathrm{min})$ \\
\hline 1 & 95 & 1 \\
\hline \multirow{3}{*}{16} & 95 & 1 \\
\cline { 2 - 3 } & 55 & 1 \\
\cline { 2 - 3 } & 68 & 16 \\
\hline 1 & 68 & 1 \\
\hline
\end{tabular}


Las muestras se enviaron a secuenciar mediante métodos estándares y se analizaron con ayuda de software apropiado. Una vez verificada la secuencia, se transformaron bacterias E. coli BL21 con el plásmido conteniendo el inserto deseado para llevar a cabo la expresión de la proteína. Una vez chequeada la correcta expresión de las proteínas por SDS-PAGE, se hicieron stocks de bacterias en glicerol al $20 \%$ y se almacenaron a $-70{ }^{\circ} \mathrm{C}$.

\subsection{Expresión y purificación.}

Bacterias provenientes de los stock de glicerol a $-70^{\circ} \mathrm{C}$, se estriaron en medio LB-agar $\left(1.5 \%\right.$ agar, $30 \mathrm{mg} / \mathrm{ml}$ kanamicina) y se crecieron $\mathrm{ON}$ a $37^{\circ} \mathrm{C}$. Posteriormente se seleccionó una colonia y se expandió en medio LB con $30 \mu \mathrm{g} / \mathrm{ml}$ de kanamicina $\mathrm{ON}$ a $37^{\circ} \mathrm{C}$ con agitación constante. Luego se inocularon $500 \mathrm{ml}$ de medio LB+kanamicina y se crecieron con agitación constante a $37^{\circ} \mathrm{C}$. Cuando el cultivo alcanzó una DO de 0.5 a $600 \mathrm{~nm}$ se indujo la expresión con IPTG (concentración final $0.4 \mathrm{mM}$ ) durante $2 \mathrm{~h}$ también con agitación constante a 37 ${ }^{\circ} \mathrm{C}$. Por último las bacterias se cosecharon por centrifugación a 7000 rpm durante $10 \mathrm{~min}$. Los pellets se guardaron a $-70^{\circ} \mathrm{C}$ hasta el momento de ser utilizados; lvego se resuspendieron en una solución de Tris- $\mathrm{HCl} 20 \mathrm{mM} \mathrm{pH}$ 7,4 NaCl $150 \mathrm{mM}$ (buffer A) con $6 \mathrm{M} \mathrm{GndHCl}$ y se dejaron en agitación suave a temperatura ambiente durante $4 \mathrm{~h}$ a fin de lisar las células. Posteriormente se centrifugó a 10000 rpm durante 10 min a $4{ }^{\circ} \mathrm{C}$ y el sobrenadante se dializó ON contra buffer $\mathrm{A}$ a $4{ }^{\circ} \mathrm{C}$. Previo a la purificación, el extracto proteico se clarificó por centrifugación (10000 rpm 10 min, $\left.4^{\circ} \mathrm{C}\right)$.

La purificación se realizó por cromatografía de afinidad por metales, empleando columnas cargadas con $\mathrm{NiSO}_{4}$ IMAC Sepharose 6 Fast Flow, (GE Healthcare Bio-Sciences AB, Uppsala, Suiza) que retienen con alta afinidad el péptido His-tag. Luego de eluídas las fracciones se chequearon por SDS-PAGE 16\%. La fracción conteniendo la apoA-I unida al péptido de fusión His-tag se incubó con ácido fórmico al $45 \%$ a $60^{\circ} \mathrm{C}$ durante $5 \mathrm{~h}$ a fin de generar la ruptura entre el péptido de fusión y la apoA-l. Luego la fracción se dializó ON contra buffer A más $\mathrm{NaOH}$ (equimolar con las unidades de ácido fórmico agregadas previamente). Se 
realizó una segunda diálisis contra buffer A durante $4 \mathrm{~h}$. Las muestras se pasaron una segunda vez por la columna de afinidad a fin de separar el péptido de fusión de la proteína. La fracción conteniendo a la proteína pura se dializó contra Tris- $\mathrm{HCl}$ $20 \mathrm{mM}$ pH $7.4 \mathrm{ON}$ a $4{ }^{\circ} \mathrm{C}$. Por último el producto purificado se cuantificó por absorbancia a $280 \mathrm{~nm}\left(\varepsilon=1,13 \mathrm{mg} / \mathrm{ml}^{-1}\right)$, se fraccionó en alícuotas de $\sim 1 \mathrm{ml}$ y se guardó a $-70^{\circ} \mathrm{C}$ hasta el momento de ser usado.

\subsection{Ensayos de fluorescencia.}

\subsubsection{Fundamentos de la técnica.}

La luminiscencia es la emisión de fotones desde estados electrónicamente excitados. La fluorescencia es la emisión que resulta del regreso de un electrón apareado a su nivel basal. Las moléculas con capacidad fluorescente, poseen por lo general electrones deslocalizados, típicamente en dobles enlaces conjugados.

El proceso de fluorescencia puede ser ilustrado de manera simplificada por el diagrama de Jablonski (Fig. 4.3.1). Los niveles electrónicos basal, primer y segundo están representados por SO, S1 y S2, respectivamente. En cada uno de estos niveles energéticos los fluoróforos pueden existir en distintos niveles vibracionales, mostrados como 0, 1, 2, etc. En este diagrama se excluyen un número de interacciones que pueden ocurrir en el estado excitado, como por ejemplo apagado, transferencia de energía e interacción con solventes. Un fluoróforo puede ser excitado a niveles vibracionales superiores de $S 1$ o también a S2. Salvo por excepciones, las moléculas suelen relajarse rápidamente a los niveles vibracionales inferiores de S1. Este proceso se llama interconversión interna y ocurre en $10^{-12} \mathrm{seg}$. Este tiempo relativamente corto en relación a la vida media de la fluorescencia (del orden de 10-8 seg), hace que la conversión interna ocurra casi completamente previo a la emisión. Así la emisión de fluorescencia ocurre desde estados excitados térmicamente equilibrados. 
Figura 4.3.1. Diagrama de Jablonski

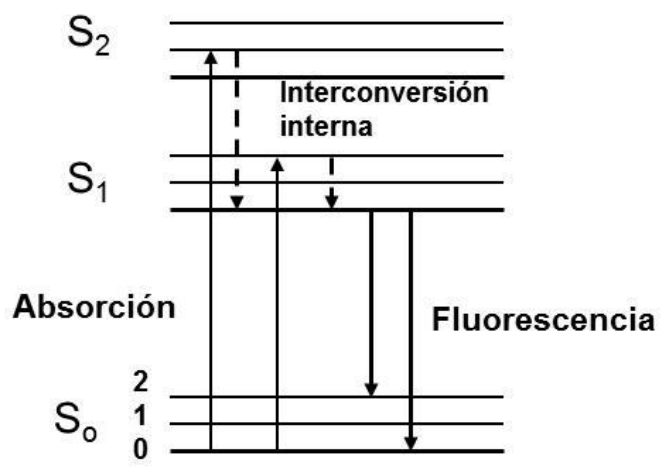

Los espectros de fluorescencia son presentados como espectros de emisión, en los cuales se determina el cambio de intensidad de fluorescencia en función de la longitud de onda, esta emisión dependerá de la estructura química del fluoróforo y del solvente en que se encuentre disuelto. Así tanto la intensidad como el corrimiento del máximo de emisión espectral dan información importante. La primera depende de la concentración de fluoróforo, de la interacción del mismo con su entorno, de la transferencia de energía con la misma especie o con otra, del apagado por otra especie, etc. Todo esto determinará el rendimiento cuántico, o sea la relación entre fotones absorbidos versus los emitidos. El segundo proceso es llamado corrimiento de Stokes. Excepto para átomos en fase vapor, de la observación del diagrama de Jablonski se hace evidente que la energía de emisión es típicamente menor que la de absorción, y por lo tanto la fluorescencia ocurre a mayores longitudes de onda que la excitación. Los fluoróforos pueden presentar además, corrimientos adicionales debido a la relajación de los estados excitados ocasionados por solventes polares, ó sufrir reacciones químicas durante el estado excitado.

A fin de estudiar estructura proteica puede utilizarse fluoróforos sintéticos (fluoresceína, bis-ANS, etc.), ó utilizar la capacidad de fluorescencia intrínseca, la que se origina de los aminoácidos aromáticos Tyr, Trp y Phe. El grupo indol del Trp es el que predomina cuando las proteínas absorben y emiten luz en la región del Ultravioleta del espectro. La Tyr tiene una intensidad de emisión similar a la del Trp, pero su máximo de emisión está dado en longitudes de onda menores que la de éste y su fluorescencia puede ser modificada por interacciones con péptidos o aminoácidos como el Trp, además la misma aumenta en proteína 
desnaturalizadas, debido a cambios en el pKa del fenol que favorecerían el estado excitado. La fluorescencia de la fenilalanina adquiere importancia cuando en proteínas no existe residuos de Trp o de Tyr, cosa que raramente ocurre. La emisión del Trp es altamente sensible al ambiente que lo rodea, sufriendo un corrimiento hacia longitudes de onda mayores (hacia el rojo del espectro) cuando el medio al que se expone este residuo es acuoso. A fin de facilitar la interpretación de la influencia del medio en el que una proteína se encuentra sobre su estructura, se puede definir la longitud de onda (en $295 \mathrm{~nm}$ ) a fin de excitar casi exclusivamente a los residuos Trp (Fig. 4.3.2).
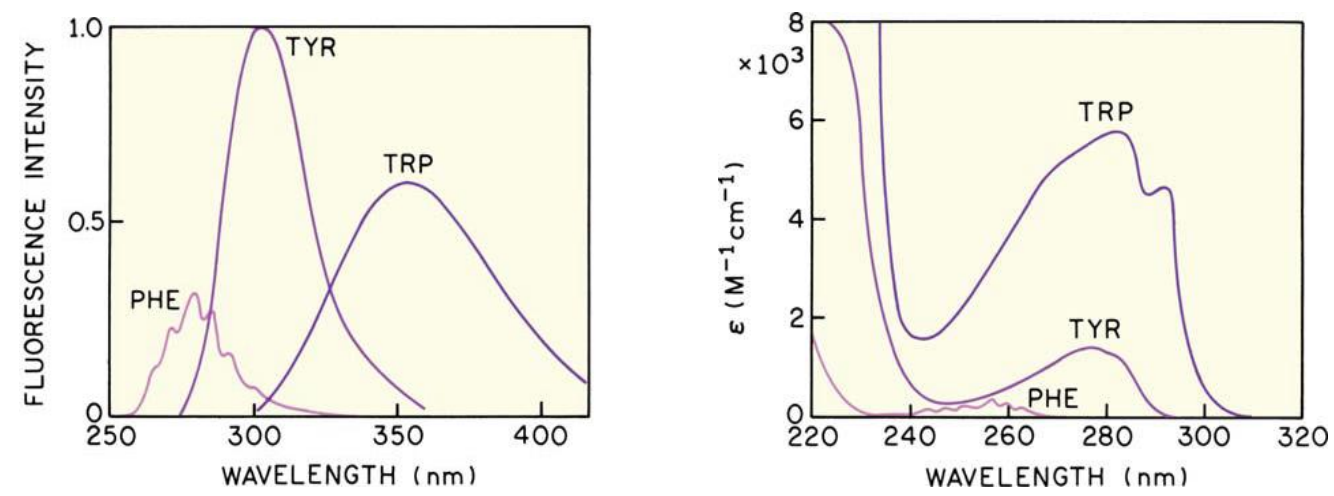

Figura 4.3.2. Espectros de absorción y emisión de los aminoácidos fluorescentes en $\mathrm{H}_{2} \mathrm{O}$ a pH 7. Extraído de Lakowicz (2006) - Principles of fluorescence spectroscopy.

\subsubsection{Desnaturalización química mediada por GndHCl.}

La exposición de una proteína a agentes caotrópicos (como la guanidina), induce la desnaturalización de la misma, resultando en una exposición de aminoácidos aromáticos (como el Trp) que en la estructura nativa se encuentran en mayor o menor medida protegidos del medio acuoso por la conformación terciaria. La concentración de guanidina requerida para inducir el desplegamiento depende de la estabilidad conformacional de la misma, y por lo tanto el seguimiento del corrimiento de la fluorescencia del Trp en función de la concentración de guanidina permite el cálculo de la energía libre de desnaturalización. Las proteínas se incubaron a una concentración final de 3,6 $\mu \mathrm{M}$ 
en buffer Mc Ilvaine $\left(\mathrm{Na}_{2} \mathrm{HPO}_{4}\right.$ 0,2M; ácido cítrico 0,1 M) a pH 7,4; 6,0; 5,0 y 4,0; con concentraciones crecientes de $\mathrm{GndHCl}$ disuelta en el $\mathrm{pH}$ indicado en cada caso a $25{ }^{\circ} \mathrm{C}$. El centro de masa del espectro de fluorescencia del Trp se obtuvo por excitación a $295 \mathrm{~nm}$ registrando la emisión entre 310 y $420 \mathrm{~nm}$ en un espectrofluorómetro SLM 4800 actualizado por Olis. La desnaturalización química de las variantes de apoA-I fue seguida por el corrimiento en el centro de masa de la fluorescencia intrínseca de los residuos Trp de la apo (4 residuos por molécula). La variación de energía libre $\Delta G$ en ausencia de desnaturalizante $\Delta G$ fue obtenido de los valores espectrales, asumiendo un proceso en dos estados (nativo y desnaturalizado). La dependencia de $\Delta \mathrm{G}$ con la concentración de guanidina ([GndHCl]), puede ser deducida como:

$$
\Delta G=\Delta G^{0}+m[G n d H C l]
$$

(Pace, 1986). El parámetro m fue considerado como proporcional a la exposición de la superficie hidrofóbica en función de la desnaturalización. En términos de la fracción de proteína desplegada $a_{g}$ a cada [GndHCl], La ecuación (1) puede ser expresada como:

$$
\ln \left[a_{g} / 1-a_{g}\right]=\ln K_{0}+m[G n d H C l] / R T
$$

donde $\mathrm{K}_{0}$ es la constante de equilibrio en ausencia de $\mathrm{GndHCl}$, R es la constante de gases y $T$ es la temperatura de trabajo (298 OK). Del gráfico lineal de $\ln \left[a_{g} / 1-a_{g}\right]$ vs [GndHCl], es posible obtener $K_{0}$ de la ordenada al origen, y de allí $\Delta G^{0}$ como:

$$
\Delta G^{0}=-R T \ln K_{0}
$$

\subsubsection{Apagamiento (Quenching) de Trp mediado por acrilamida.}

La intensidad de fluorescencia puede ser disminuida por distintos procesos que se describen como apagado o "quenching". El quenching colisional ocurre cuando el fluoróforo en el estado activado es desactivado por contacto con otras 
moléculas en solución. Las moléculas no son químicamente alteradas en el proceso. Para el quenching colisional la disminución en intensidad es descripta por la ecuación de Stern-Volmer

$$
F 0 / F=1+K[Q]
$$

Donde FO y $\mathrm{F}$ son la intensidad de fluorescencia en ausencia y en presencia de quencher respectivamente, $K$ es la constante de Stern-Volmer y [Q] es la concentración del quencher (acrilamida).

La constante de Stern-Volmer indica la sensibilidad de fluoróforo al quencher. Un fluoróforo protegido en una macromolécula es usualmente inaccesible al quencher disuelto en solvente acuoso, resultando en un valor de $\mathrm{K}$ bajo. Los mayores valores de $\mathrm{K}$ se encuentran en fluoróforos libres en solución. Existe una gran variedad de moléculas que pueden actuar como quenchers colisionales, incluyendo oxígeno, halógenos, aminas y acrilamida, variando el mecanismo por el cual ocurre el apagamiento con cada par fluoróforo-quencher. El quenching del indol del Trp por acrilamida es probablemente debido a la transferencia de electrones del indol a la acrilamida, lo que no ocurre en el estado basal (Lakowicz, 2006).

La exposición de los residuos de Trp al solvente se determinó excitando a 295 $\mathrm{nm}$ y registrando el espectro de emisión entre 310 y $400 \mathrm{~nm}$. Las muestras se incubaron en una concentración de 3,6 $\mu \mathrm{M}$ en buffer Mc Ilvaine a pH 7,4; 6,0; 5,0 o 4,0 dependiendo el caso y se incubaron en concentraciones crecientes de acrilamida. Los parámetros de quenching se determinaron mediante una modificación de la ecuación de Stern-Volmer (Lakowicz, 2006):

$$
F_{0} / \Delta F=1 /\left(f_{a} \times K[Q]\right)+1 / f_{a}
$$

donde $f_{a}$ es la fracción de fluorescencia inicial que es accesible al quencher, y $\Delta F$ es la fluorescencia remanente luego de agregar acrilamida en cada punto. $K$ y $f_{a}$ se obtiene de graficar $F_{0} / \Delta F$ versus $1 /[Q]$. 


\subsubsection{Fluorescencia de bis-ANS.}

Para monitorear la exposición de bolsillos hidrofóbicos en la apoA-l wł y sus variantes, se utilizó la sonda bis-ANS (Munishkina y Fink, 2007). La solución de bisANS se preparó en metanol de calidad analítica en una concentración final de 1 $\mathrm{mM}$.

Para el caso de apoA-I wt las muestras fueron incubadas en una concentración de 3,6 $\mu \mathrm{M}$ en buffer Mc Ilvaine a $\mathrm{pH} 7,4 ; 6,0 ; 5,0$ y 4,0, y permanecieron $24 \mathrm{~h}$ a $37^{\circ} \mathrm{C}$. Luego se agregó bis-ANS en una relación molar sonda:proteína 2:1. La fluorescencia se determinó en un lector de placas (Beckman DTX 880) y se usaron microplacas opacas con fondo óptico (Nunc 96 wells black optical botton). Los filtros de excitación y emisión usados fueron de 395 y $490 \mathrm{~nm}$ respectivamente.

Para el ensayo de titulación con bis-ANS las tres proteínas, en una concentración de 3,6 $\mu \mathrm{M}$, fueron incubadas en buffer Mc Ilvaines a pH 7,4. Las muestras se titularon con concentraciones crecientes de bis-ANS, la longitud de onda de excitación se ajustó en $395 \mathrm{~nm}$ y el espectro de emisión se registró entre 450 y $550 \mathrm{~nm}$.

A fin de analizar la estabilidad de la conformación espacial a la desnaturalización química, las distintas variantes de apoA-I fueron incubadas como se menciona arriba a pH 7,4, con bis-ANS en relación molar sonda:proteína de 1:5 y se adicionaron cantidades crecientes de $\mathrm{GndHCl}$. Los espectros se registraron de igual modo que el caso anterior.

\subsection{Agregación de proteínas seguida por fluorescencia de tioflavina-T (ThT).}

El rendimiento cuántico de la ThT es muy bajo en solución acuosa, pero aumenta considerablemente cuando se une a proteínas con conformación de tipo amiloide (Levine, 1993). ApoA-I wt, en una concentración de 7,2 $\mu \mathrm{M}$ se incubó a $\mathrm{pH} 7,4 ; 6,0 ; 5,0$ y 4,0 en buffer Mc Ilvaine durante $24 \mathrm{~h}$ a $37^{\circ} \mathrm{C}$. Luego a todas las muestras se les agregó ThT en una concentración final de $10 \mu \mathrm{M}$ y se registró fluorescencia empleando un lector de placas (Beckman DTX 880). El filtro 
de excitación utilizado fue de $430 \mathrm{~nm}$, mientras que para la emisión se usó un filtro $480 \mathrm{~nm}$. A continuación las muestras se centrifugaron a $800 \times \mathrm{g}$ durante 10 minutos y se registró, de igual modo que antes, la fluorescencia remanente en el sobrenadante, el cual había sido previamente trasvasado a fin de poder discriminar la fluorescencia que corresponde a los productos de agregación. El porcentaje de proteína sedimentada se determinó cuantificando la proteína remanente en el sobrenadante. Este paso se llevó a cabo por cuantificación fluorométrica empleando el equipo Qubit (Invitrogen) y los reactivos correspondientes para determinación de proteínas. Todo el experimento se realizó en microplacas opacas de 96 wells con fondo óptico.

\subsection{Unión a heparina determinada por dispersión de luz (light scattering) y unión de tioflavina-T.}

La unión de la proteína a heparina se siguió por la técnica de dispersión de luz (light scattering) como parámetro sensible al aumento del tamaño de partículas en solución. Para este ensayo apoA-I wt, en una concentración de 1,8 $\mu \mathrm{M}$, se incubó durante $2 \mathrm{~h}$ a pH 7,4; 6,0; 5,0 y 4,0 en buffer Mc Ilvaine en presencia o no de heparina. La relación molar empleada fue aproximadamente de 2:1 heparina:proteína. La dispersión de luz fue monitoreada a $90^{\circ}$ usando el espectrofluorómetro SLM4800, la longitud de onda de excitación y emisión se ajustaron, en ambos casos, en 400nm.

En un tipo distinto de experimento, apoA-I w' en una concentración de 7,2 $\mu \mathrm{M}$, se incubó a pH 5,0 en buffer Mc llvaine, en presencia o no de heparina ó CINa $0,5 \mathrm{M}$, durante $24 \mathrm{~h}$ a $37^{\circ} \mathrm{C}$. Luego a todas las muestras se les agregó ThT en una concentración final de $10 \mu \mathrm{M}$ y se registró la fluorescencia en un lector de placas como fue descrito en el punto 4.4 . 


\subsection{Procesamiento pro-inflamatorio de las variantes de apoA-I.}

\subsubsection{Procesamiento inducido por neutrófilos activados.}

Neutrófilos polimorfonucleares humanos (PMNs) fueron aislados a partir de sangre venosa de donantes sanos por sedimentación por centrifugación empleando un gradiente de Ficol Hypaque (Sigma-Aldrich, (St Lovis, MO)). Luego de ser purificados se confirmó por trypan blue una viabilidad mayor al $98 \%$ para ser usados en los ensayos. Las células se resuspendieron en solución salina de Hank pH 7,4, conteniendo $\mathrm{Cl}_{2} \mathrm{Ca} 1 \mathrm{mM}, \mathrm{Cl}_{2} \mathrm{Mg} 0,5 \mathrm{mM}$ y glucosa $1 \mathrm{mg} / \mathrm{ml}$ (HBSS). El número se ajustó en 1 × $10^{5}$ células / $500 \mu$ l. Los neutrófilos, incubados a $37^{\circ} \mathrm{C}$, fueron estimulados con 12-O-tetradecanoilforbol-13-acetato (TPA) durante 5 minutos, lvego se agregaron la variantes de apoA-I en una concentración de 7,2 $\mu \mathrm{M}$ y la incubación se dejó seguir durante 45 minutos. Por último se frenó la reacción centrifugando las células a $1000 \times 9$ durante 5 minutos. Una fracción de las proteínas en el sobrenadante se analizó por SDS-PAGE $16 \%$ seguido por western blot usando un anticuerpo policlonal contra apoA-I humana (Jaureguiberry y col., 2010) como se describe en el punto 4.10.2. Otra fracción de la muestra se incubó durante $24 \mathrm{~h}$ a $37^{\circ} \mathrm{C}$ y se ensayó la unión a Tht como ya fue descripto previamente para otros ensayos.

\subsubsection{Ensayo con metaloproteasa-12 (MPP-12).}

ApoA-I wt, Gly26Arg y Lys 107-0, en una concentración de 7,2 $\mu \mathrm{M}$, se incubaron con MMP-12 (Sigma-Aldrich)) en una relación molar MMP-12:proteína 1:3000. La reacción se llevó a cabo a $37^{\circ} \mathrm{C}$ durante $3 \mathrm{~h}$ y, luego, se detuvo adicionando EDTA en una concentración de $5 \mathrm{mM}$. El buffer de reacción estuvo compuesto por Tris-HCl $50 \mathrm{mM} \mathrm{pH} \mathrm{7,4,} \mathrm{CINa} \mathrm{0,15} \mathrm{M,} \mathrm{NaN} 30,02 \%$ y $\mathrm{Cl}_{2} \mathrm{Ca} 10 \mathrm{mM}$. Los productos de reacción se analizaron por SDS-PAGE $16 \%$ seguido por western blot usando un anticuerpo policlonal contra apoA-I como fue descrito en 4.10.2. También se ensayó la unión a ThT como ya fue descripto previamente para otros ensayos. 


\subsubsection{Oxidación inducida por hipoclorito de sodio $(\mathrm{HClO})$.}

ApoA-I wt, diluida en HBSS pH 7,4 hasta una concentración de 7,2 $\mu \mathrm{M}$, se incubó con concentraciones crecientes de $\mathrm{HClO}$ a temperatura ambiente. Para estar seguros que la reacción fue completa, se la dejó proseguir durante 1 h. La solución de $\mathrm{HClO}$ se preparó en Tris- $\mathrm{HCl} 400$ mM pH 8,9 más EDTA 200 mM y la concentración se determinó por absorbancia a $292 \mathrm{~nm}\left(\varepsilon=350 \mathrm{M}^{-1} \mathrm{~cm}^{-1}\right)$. Los productos de reacción se analizaron por SDS-PAGE 12,5\% revelado con tinción de plata y por western blot usando un anticuerpo policlonal contra apoA-l. También se ensayó la unión a ThT como ya fue descripto previamente para otros ensayos.

\subsection{Remoción de colesterol.}

A fin de analizar la posibilidad de que la apoA-I sometida a un entorno proinflamatorio pierda su función biológica, se ensayó una función altamente caracterizada de la apoA-I, como lo es la remoción de colesterol desde células en cultivo. Células de ovario de Hámster Chino (CHO) fueron sembradas y crecidas en medio MEM, suplementado con penicilina/estreptomicina (100 unidades/ml) y $10 \%$ de suero fetal bovino (FBS) a $37^{\circ} \mathrm{C}$ en atmósfera de $5 \% \mathrm{CO}_{2}$ (Gonzalez y col., 2008). Luego de llegar a confluencia las monocapas celulares fueron lavadas 3 veces con PBS e incubadas $24 \mathrm{~h}$ con $\mathrm{MEM}+0,05 \mu \mathrm{Ci} / \mathrm{ml}$ de 1,2-3H(N)-Colesterol (Amersham Biosciences, Pittsburgh, PA, USA) + $50 \mu \mathrm{g} / \mathrm{ml}$ de Colesterol frío. Transcurridas las 24 hs se removió el medio de cultivo, se lavaron las placas 3 veces con $M E M+$ albúmina (2 $\mathrm{mg} / \mathrm{ml}$ ) y se incubaron otras $24 \mathrm{~h}$ con el mismo medio, para equilibrar los pooles intracelulares y remover todo resto de colesterol no incorporado por las células. A continuación se incubaron por 12 h con MEM libre de suero, conteniendo $12 \mu \mathrm{g} / \mathrm{ml}$ de apoA-l, tratada o no con $\mathrm{HClO}$ como fue descrito en el punto 4.6.3. El control negativo se obtuvo de placas incubadas de igual manera en ausencia de apoA-I. La remoción se cuantificó luego de 12 h, midiendo radiactividad en el medio de cultivo por centelleo líquido, expresando en función de la radiactividad total incorporada en cada placa. 


\subsection{Microscopía.}

\subsubsection{Microscopía electrónica de transmisión (TEM).}

Para las observaciones con TEM las distintas muestras en una concentración de $14,4 \mu \mathrm{M}$, se incubaron a $37^{\circ} \mathrm{C}$ durante $24 \mathrm{~h}$. Luego las muestras se centrifugaron a $800 \times \mathrm{g}$ y el pellet se resuspendió en menor volumen. Una alícuota de cada muestra se colocó en el soporte y fueron tratadas con solución al $2 \%$ de acetato de uranilo durante 5 minutos para lograr una tinción negativa.

Las imágenes se obtuvieron utilizando un equipo JEOL-1200 EX operando a $100 \mathrm{kV}$ (Facultad de Ciencias Veterinarias, UNLP).

\subsubsection{Microscopía de fuerza atómica (AFM).}

Las muestras estudiadas en cada caso por AFM se incubaron previamente en una concentración de $21,6 \mu \mathrm{M}$ a $37^{\circ} \mathrm{C}$ durante $24 \mathrm{~h}$. Luego $10 \mu \mathrm{l}$ de muestra se colocaron en mica muskovita, que fue el soporte elegido para realizar las observaciones. La muestra se dejó secar en una atmosfera saturada con $\mathrm{N}_{2}$, luego se lavó en dos oportunidades con $\mathrm{H}_{2} \mathrm{O}$ desionizada para remover sales y se dejó secar nuevamente. Para el caso de las muestras a pH 7,4, puesto que apoA-I a ese $\mathrm{pH}$ tiene una carga parcial negativa y siendo que la mica empleada tiene carga negativa, a fin de evitar repulsiones electrostáticas y como lo recomiendan los protocolos para el caso, previo a ser colocadas en la mica se les agregó $\mathrm{CaCl}_{2}$ en una concentración final de $1 \mathrm{mM}$.

Todas las imágenes se obtuvieron usando un microscopio MultimodeNanoscope (Veeco, Santa Barbara, California) operando en tapping-mode empleando una punta modelo Arrow-NCR-50 Nano World, con una frecuencia de resonancia de $258 \mathrm{kHz}$, constante de fuerza de $42 \mathrm{~N} / \mathrm{m}$ y radio de tip de 5-10 nm. Las tasas de escaneo fueron de 1- 1,5 Hz (Instituto de Investigaciones Fisicoquímicas Teóricas y Aplicadas (INIFTA)). 


\subsection{Activación de macrófagos murinos.}

\subsubsection{Cultivo de células RAW 264,7.}

Macrófagos murinos RAW 264,7 (ECACC, Salisbury, UK) fueron crecidos en medio DMEM con $10 \%$ de SFB, $100 \mathrm{U} / \mathrm{ml}$ de penicilina y $100 \mu \mathrm{g} / \mathrm{ml}$ de estreptomicina, en una estufa a $37^{\circ} \mathrm{C}$ y $5 \%$ de $\mathrm{CO}_{2}$. Para todos los experimentos las células no superaron los 20 pasajes.

\subsubsection{Ensayo de viabilidad celular con MTT.}

Las células fueron colocadas en placas de 96 wells en una concentración de $6 \times 10^{4}$ células/well. Después de $24 \mathrm{~h}$ a $37^{\circ} \mathrm{C}$ se removió el medio y se adicionó DMEM con $0,5 \%$ de SFB, $100 \mathrm{U} / \mathrm{ml}$ de penicilina y $100 \mu \mathrm{g} / \mathrm{ml}$ de estreptomicina, en presencia $O$ ausencia de $50 \mathrm{\mu g} / \mathrm{ml}$ de polimixina B. Luego se agregaron las variantes de apoA-I o lipopolisacárido bacteriano (LPS) en una concentración de 1 $\mu \mathrm{g} / \mathrm{ml}$. Pasadas $24 \mathrm{~h}$ se determinó la actividad redox, como indicador de la viabilidad celular, midiendo la conversión del MTT en formazán. Para esto, luego de cambiar el medio, el MTT se adicionó en una concentración final de 0,5 mg/ml y se dejó incubar durante 20 minutos a $37^{\circ} \mathrm{C}$. Por último se removió el medio y los precipitados de formazán se solubilizaron en DMSO. Se determinó absorbancia a $490 \mathrm{~nm}$ usando un lector de placas.

4.9.3. Producción de radicales libres del oxígeno (ROS) medida por DCFH-DA.

La producción intracelular de ROS se evaluó utilizando la sonda no polar DCFH-DA. La sonda difunde dentro de la célula, queda atrapada cuando es desacetilada, y en presencia de $\mathrm{H}_{2} \mathrm{O}_{2}$ se oxida para producir 2', 7'diclorofluoresceína (DCF). El número de células por well y las condiciones experimentales fueron las mismas que las descriptas en el ensayo 4.9.2. Luego de 6 $\mathrm{h}$ las células fueron lavadas con DMEM e incubadas con DCFH-DA $20 \mu \mathrm{M}$ durante 30 minutos a $37^{\circ} \mathrm{C}$. Luego de un lavado con PBS, se agregó a cada well $100 \mu \mathrm{l}$ de buffer lisis (Triton X-100 1\%; ácido desoxicólico 1\%; NaCl 20 mM; Tris-HCl 25 mM; pH 
7,4). Por último se determinó la fluorescencia en un lector de placas, para el caso los filtros de excitación y emisión fueron de 485 y $525 \mathrm{~nm}$ respectivamente.

4.9.4. Producción de Factor de Necrosis Tumoral alfa (TNF-a) e Interleuquina 1-beta (IL-1 $\beta$ ).

El número de células por well y las condiciones experimentales fueron las mismas que las descriptas en el ensayo 4.9.2. Pasadas $24 \mathrm{~h}$ se colectó el sobrenadante y se ensayó la producción de TNF- a e IL-1 por reacciones inmuno enzimáticas específicas para cada caso según el protocolo descripto en cada kit (eBioscience, San Diego, CA).

\subsection{Protocolos generales de trabajo.}

\subsubsection{Electroforesis de proteínas.}

Cuando fue requerido las proteínas se separaron por electroforesis empleando como soporte poliacrilamida en condiciones desnaturalizantes (SDSPAGE). En todos los casos se realizaron geles de poliacrilamida continuos, normalmente al $16 \%$ con alguna excepción al 12,5\%. El equipo usado para tal fin fue el miniVE Vertical Electrophoresis System (Amersham, GE). Las corridas se realizaron a $120 \mathrm{~V}$.

Los geles se revelaron con solución de Coomasie Blue R-250 y, en algunos casos, por tinción con nitrato de plata.

\subsubsection{Western blot: transferencia y revelado.}

Esta técnica implica el revelado específico de proteínas resueltas por electroforesis mediante anticuerpos. Luego de corrido el gel las proteínas se transfirieron a una membrana de nitrocelulosa Hybond ECL (Amersham, GE). Para tal fin se empleó el equipo se transferencia semihúmedo de BioRad. El buffer usado fue: Tris $25 \mathrm{mM}$, glicina $192 \mathrm{mM}$, metanol 20\% v/v. La transferencia se realizó a $100 \mathrm{v}$ durante $1 \mathrm{~h}$ en frío. 
La membrana se bloqueó ON en solución de leche en polvo descremada al $3 \%$ en buffer $\mathrm{A}$ a $4{ }^{\circ} \mathrm{C}$. Luego se lavó dos veces con buffer A 10 minutos cada lavado) y se incubó durante $2 \mathrm{~h}$ a temperatura ambiente y agitación suave con anti-apoA-I humana (policlonal obtenido en conejo) en una dilución 1:100.000 realizada en buffer $\mathrm{A}$ con leche al 3\%. A continuación se realizaron otros dos lavados y se incubó con el anticuerpo secundario anti-lgG de conejo conjugado con enzima peroxidasa (BioRad) en una dilución de 1:1000 en iguales condiciones durante $1 \mathrm{~h}$. Por último se realizaron tres lavados.

Para el revelado se preparó solución de revelado A (luminol 0,044 gr/ml en DMSO, $50 \mu$; ácido cumárico 0,015 gr/ml en DMSO, $22 \mu$; Tris-HCl 1,5 M pH 8,5, 335 $\mu$ l; agua bidestilada c.s.p. $5 \mathrm{ml})$ y solución de revelado $\mathrm{B}\left(\mathrm{H}_{2} \mathrm{O}_{2} 110\right.$ volúmenes 3,2

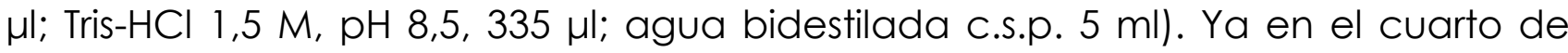
revelado, se mezclaron las soluciones A y B, y se incubó la membrana con dicha mezcla durante $1 \mathrm{~min}$. Posteriormente, se secó la membrana suavemente entre papeles de filtro, y se la colocó en un cassette de exposición (Kodak) con una placa radiográfica (Kodak), dejando exponer entre 1 y 20 min, según el experimento. Luego se colocó la placa radiográfica en solución reveladora durante 1 min, o hasta la aparición de bandas. A continuación se la retiró de la solución reveladora, se la enjuagó rápidamente, y se la sumergió en solución fijadora con agitación por 1 min.

\subsubsection{Electroforesis de ácidos nucleicos.}

La electroforesis para ADN se realizó en geles de agarosa M (Amersham Bioscience) a una concentración de $0,8 \%$ en peso (o según corresponda en base al material a separar), disuelta en buffer TBE (Tris 0,05 M; Acido Bórico 0,05 M; EDTA $1 \mathrm{mM}) \mathrm{pH}$ 8,3. Las corridas electroforéticas se realizaron en una cuba horizontal (Hoeffer HA 33, Amersham Bioscience) a $100 \mathrm{~V}$, durante 45 a 60 minutos, utilizando TBE como buffer de corrida. Los geles se tiñeron con solución de bromuro de etidio $(0,5 \mathrm{mg} / \mathrm{ml})$ y las bandas de ADN se observaron por transiluminación UV (Hoefer MacroVue UV-20). 


\subsection{Análisis estadístico.}

Para cada ensayo se hicieron al menos 3 repeticiones independientes. Los resultados representan el promedio de al menos 3 muestras. Para establecer las diferencias se realizó ANOVA seguido del test de Tukey $(p<0,05)$. 


\section{Resultados I: Implicancia de la apolipoproteína A-I wild type humana en amiloidosis.}

\subsection{Efecto del pH sobre el plegamiento y la estabilidad de apoA-I.}

La estabilidad de la proteína se estudió por la técnica de desnaturalización con $\mathrm{G}$ dHCl. La fluorescencia corresponde a la emisión intrínseca de los residuos de Trp, en el caso de apoA-I son cuatro ubicados en posición 8, 50, 72 y 108. Los cambios en centro de masa del espectro de emisión indican modificaciones del entorno que rodea estos residuos. La desnaturalización seguida por fluorescencia de Trp responde un modelo matemático de dos estados donde se considera a la proteína en estado nativo o totalmente desnaturalizada, pero no predice estructuras intermedias (Pace, 1986). Cuando el mismo ensayo de desnaturalización se realiza por dicroísmo circular en lugar de fluorescencia, se obtiene exactamente el mismo perfil, por lo que puede inferirse que el corrimiento del centro de masa de los espectros de fluorescencia de Trp se debe la perdida de estructura secundaria (Leroy y Jonas, 1994). La desnaturalización a pH 7.4 muestra un patrón de efecto cooperativo (Fig. 5.1.1). La energía libre calculada $\left(\Delta \mathrm{G}^{0}\right)$ fue de $2,3 \mathrm{Kcal} / \mathrm{mol}$, lo que sugiere que la proteína nativa tiene una estructura flexible compatible con un estado de glóbulo fundido. No se observaron modificaciones significativas en el patrón de desnaturalización a pH 5,0 respecto de la curva a pH 7,4. Sin embargo a pH 4,0 se detecta una disminución significativa en el efecto cooperativo y no puede ser definido por un modelo de dos estados (por este motivo no es posible estimar el valor de $\Delta \mathrm{G}^{0}$ ). Esto sugiere que a pH 4,0 la desnaturalización de apoA-I procede por estados intermedios parcialmente plegados.

La exposición relativa de los Trp al medio acuoso es un indicativo del estado conformacional de la proteína. Para profundizar estos estudios se realizó el ensayo de quenching (apagado) con acrilamida a diferentes valores de pH (Fig. 5.1.2). La interacción de la acrilamida con el residuo de Trp resulta en una relajación no 
radiativa del estado de excitación, detectado como una caída en la intensidad de la fluorescencia. Los parámetros de quenching obtenidos se resumen en la Tabla I. La constante de quenching (K) medida a pH 7.4 (5,62 $\left.\mathrm{M}^{-1}\right)$ está en acuerdo con lo reportado anteriormente por Davidson y colaboradores (1999). A pH 5,0 el valor de $\mathrm{K}$ fue de $5,87 \mathrm{M}^{-1}$, indicando una exposición similar de los Trp a lo obtenido a pH 7,4. Sin embargo a pH 4,0 el valor de K fue significativamente más alto (7,39 $\mathrm{M}^{-1}$ ) lo que sugiere una mayor exposición de los Trp al medio acuoso (Fig. 5.1.2, Tabla I). Calculando la fracción de fluorescencia accesible al solvente (fa) y considerando que apoA-I tiene $4 \mathrm{Trp}$, es posible estimar que a pH 7,4 y pH 5,0 aproximadamente tres residuos se encuentran expuestos al medio ( $\mathrm{fa} \sim 0,7$ ), mientras que a pH 4,0 (fa 1) los cuatro residuos están expuestos.

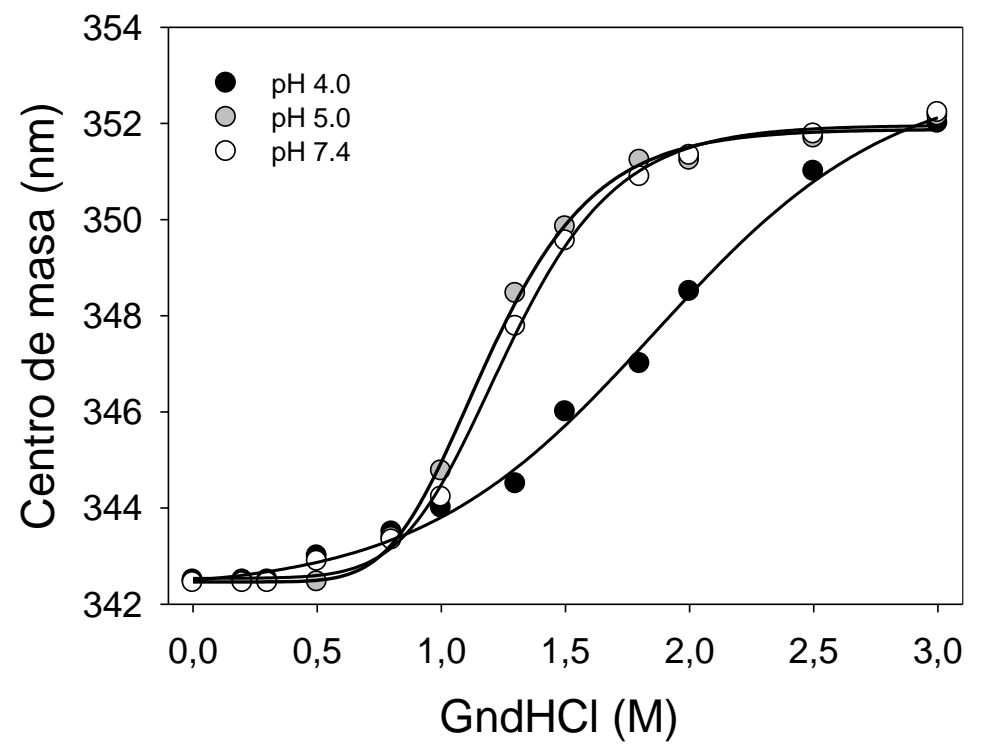

Figura 5.1.1. Efecto del pH sobre la desnaturalización química de apoA-I wt mediada por GndHCl. Los centros de masa de los espectros de fluorescencia intrínseca de apoA-I se graficaron en función de la concentración de $\mathrm{GndHCl}$. La concentración final de proteína empleada fue 3,6 $\mu \mathrm{M}$. Las muestras se excitaron a $295 \mathrm{~nm}$ y el espectro de emisión se registró entre 310 y $420 \mathrm{~nm}$. Los datos se ajustaron en base a un modelo sigmoideo. 


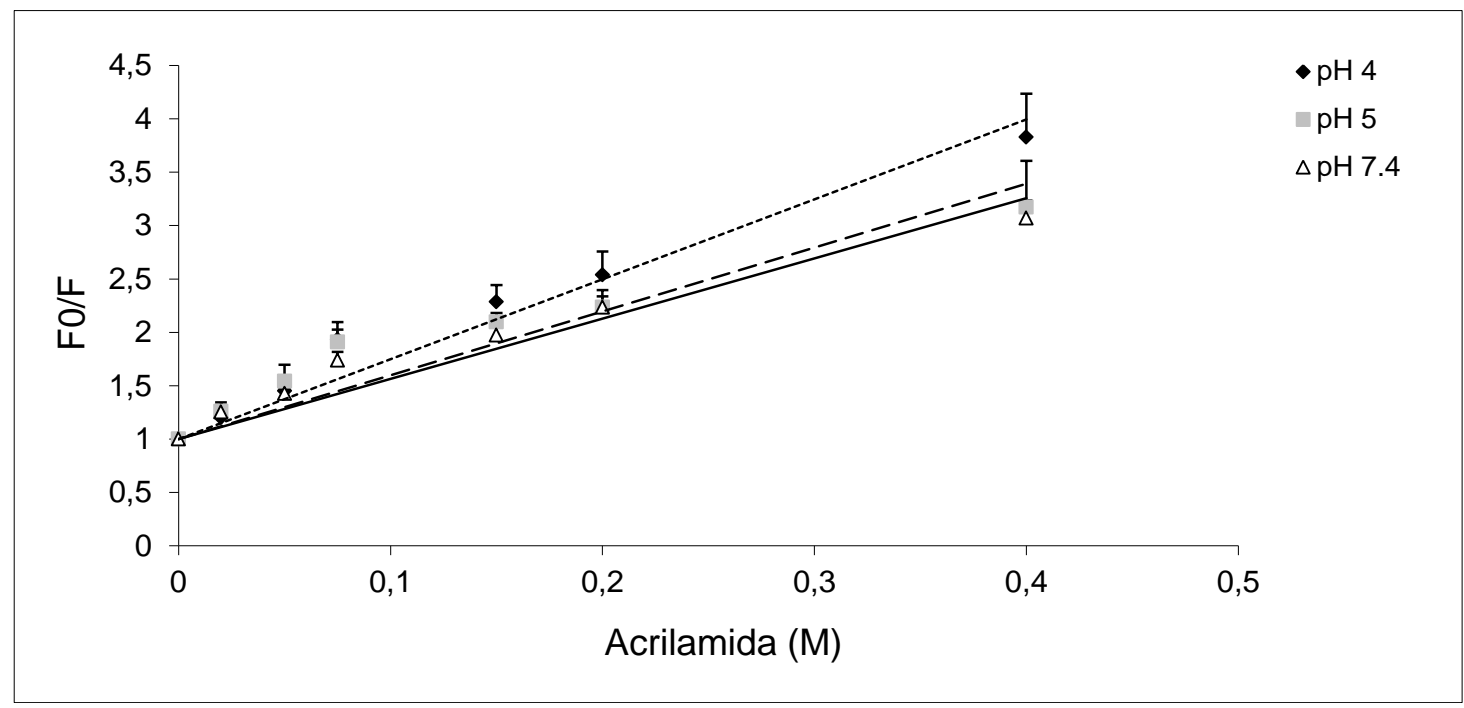

Figura 5.1.2. Quenching con acrilamida. ApoA-I wt se incubó con concentraciones crecientes de acrilamida. Los ensayos se realizaron a pH 4,0; 5,0 y 7,4. La concentración final de proteína empleada fue 7,2 $\mu \mathrm{M}$. Las muestras se excitaron a $295 \mathrm{~nm}$ y el espectro de excitación se registró entre 305 y $375 \mathrm{~nm}$. El centro de masa se utilizó para calcular la proporción $F_{0} / F_{\text {. }} F_{0}$ : intensidad inicial en ausencia de acrilamida; $F$ : intensidad correspondiente a cada concentración de acrilamida.

\begin{tabular}{|c|c|c|c|}
\hline $\mathrm{pH}$ & $\Delta \mathrm{G}^{0}(\mathrm{Kcal} / \mathrm{mol})$ & $\mathrm{K}\left(\mathrm{M}^{-1}\right)$ & $\mathrm{f}_{\mathrm{a}}$ \\
\hline 7,4 & $2,3+/-0,3$ & $5,62+/-0,38$ & $0,66+/-0,06$ \\
\hline 5,0 & $2,2+/-0,4$ & $5,87+/-0,52$ & $0,73+/-0,03$ \\
\hline 4,0 & - & $7,39+/-0,39$ & $0,97+/-0,09$ \\
\hline
\end{tabular}

Tabla I. Estabilidad de apoA-I wt y exposición al solvente de los residuos de Trp en función del pH.

Para indagar en los cambios conformacionales que pueda sufrir la apoA-I respecto del $\mathrm{pH}$, se hizo uso de la sonda fluorescente bis-ANS, la cual se emplea con frecuencia para censar bolsillos hidrofóbicos (Martins y col., 2003). Esta sonda no implica uniones covalentes con la proteína y su rendimiento cuántico se incrementa más de 100 veces cuando se une a regiones hidrofóbicas. Los estados parcialmente plegados y de glóbulo fundido son las formas más accesibles para las sonda bis-ANS (Munishkina y Fink, 2007). En la figura 5.1.3. se observa que la fluorescencia de bis-ANS es mayor en apoA-I (previa incubación a $37^{\circ} \mathrm{C}$ durante 
24h) a pH 5,0; 6,0 y 7,4, y disminuye significativamente a pH 4,0. Este resultado sugiere la desorganización en la conformación proteica, con pérdida de la configuración de glóbulo fundido.

Todos estos resultados sugieren que a pH fisiológico, apoA-I exhibe una conformación flexible la cual es preservada ante la acidificación leve del medio $(\mathrm{pH} 5,0)$. Pero los parámetros conformacionales se ven drásticamente afectados a $\mathrm{pH} 4,0$.

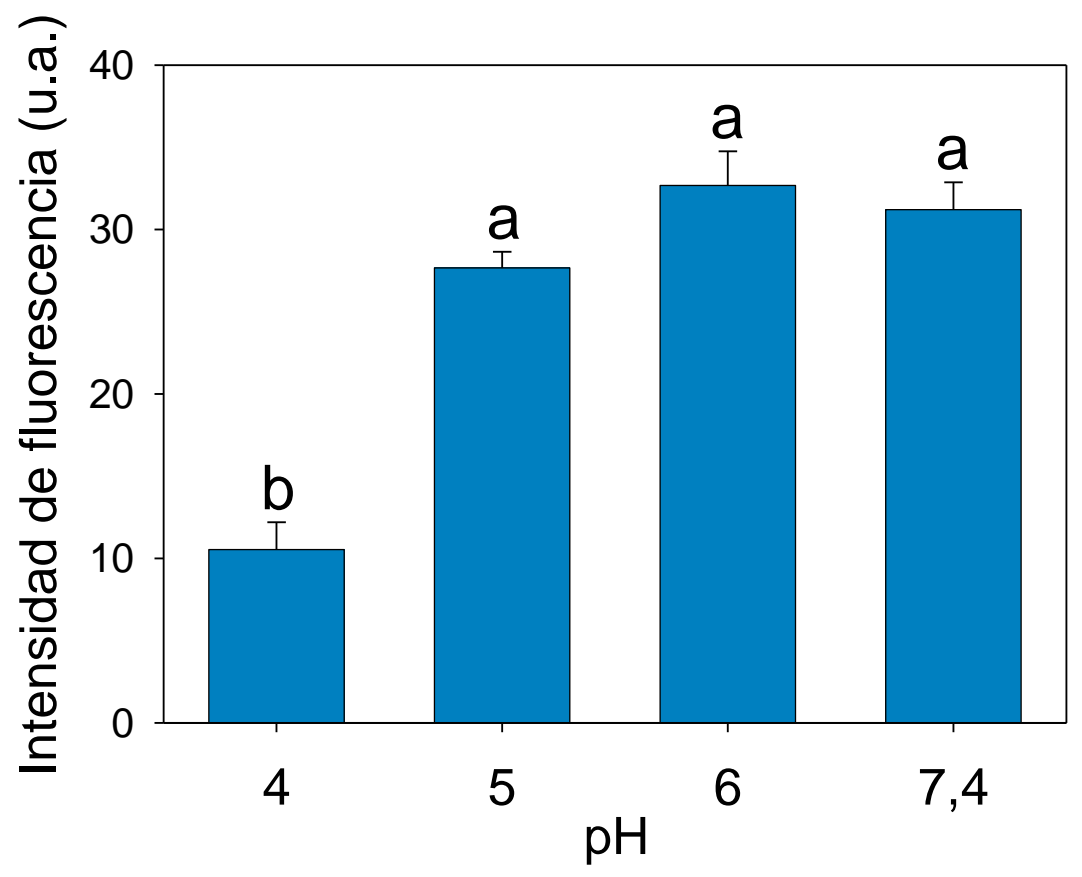

Figura 5.1.3. Unión a bis-ANS en función del pH. ApoA-I se incubó a pH 4;5;6 y 7,4 (buffer Mcllvaine) durante $24 \mathrm{~h}$ a $37^{\circ} \mathrm{C}$. La concentración final de proteína empleada fue $3,6 \mu \mathrm{M}$. La relación molar sonda: proteína fue 2:1. La fluorescencia se leyó en un lector de microplacas (filtro excitación: $395 \mathrm{~nm}$, filtro emisión: $490 \mathrm{~nm}$ ), para el caso se utilizaron placas opacas con fondo óptico. Letras diferentes implican diferencias significativas $(p<0,05)$.

\subsection{Unión de Tioflavina-T y análisis de los agregados de apoA-l.}

El mal plegamiento de ciertas proteínas resulta en la formación de distintas especies, incluyendo agregados tipo fibras amiloides y oligómeros solubles, ambos implicados en un gran número de enfermedades (Uversky, 2010; Shao y col., 2008). Para determinar como la variación en el pH induce formación de agregados proteicos, se cuantificó la unión de ThT. El rendimiento cuántico de esta sonda es muy bajo en soluciones acuosas, pero cuando se une a estructuras de tipo 
amiloides se incrementa significativamente. Si bien la Tht se une con mayor afinidad a estructuras de tipo fibrilares, se ha reportado que también hay fluorescencia significativa cuando se une a oligómeros (Martins y col., 2006). ApoAI, en una concentración 7,2 $\mu \mathrm{M}$ fue incubada a diferentes $\mathrm{pH}$ durante $24 \mathrm{~h}$ a $37^{\circ} \mathrm{C}$. A continuación, se midió la fluorescencia de las muestras, y luego se centrifugaron a baja velocidad (800 × g, 10 minutos), determinando el porcentaje de proteína remanente en solución. En la figura 5.2.1 se observa que a pH 7,4 y pH 6,0 la fluorescencia de Tht fue muy baja (valores similares a los obtenidos solo con buffer), en esas condiciones la proteína permanece soluble después de la centrifugación. La fluorescencia se incrementa significativamente a pH 5,0, y se registra un $15 \%$ de sedimentación de proteína, sugiriendo la formación de agregados insolubles. A pH 4,0 la unión de ThT es aún más alta y se condice con una mayor sedimentación de proteína luego de la centrifugación. Estos resultados indican que la acidificación del medio promueve la formación de agregados insolubles que unen ThT en apoA-I. La figura 5.2.1 muestra además la intensidad de Tht remanente en el sobrenadante luego de la centrifugación mencionada, mostrando ser despreciable a todos los pH analizados (círculos blancos en la figura). Este resultado indica la ausencia de complejos solubles en nuestras condiciones de medida.

A continuación se caracterizó la morfología de los agregados de apoA-I por microscopía electrónica. Para esto la proteína se incubó a una concentración de $14,4 \mu \mathrm{M}$ a $37^{\circ} \mathrm{C}$ durante $24 \mathrm{~h} \mathrm{a} \mathrm{pH} \mathrm{5,0} \mathrm{y} \mathrm{pH} \mathrm{7.4.} \mathrm{Como} \mathrm{se} \mathrm{esperaba,} \mathrm{a} \mathrm{pH} \mathrm{7,4} \mathrm{se}$ observó un patrón homogéneo sin la presencia de agregados (Fig. 5.2.2.A). La estructura más relevante a pH 5,0 fueron oligómeros con un diámetro entre 10 y 50 $\mathrm{nm}$ (Fig. 5.2.2.B), similar a los oligómeros reportados para otras proteínas amiloides (Munishkina y col., 2008; Sandberg y col., 2010). Estas especies se encontraron a distintos tiempos de incubación pero no se observó la formación de estructuras fibrilares, inclusive después de 48 días de incubación a pH 5,0 (Fig. 5.2.2.C). Para profundizar la caracterización morfológica, se realizó microscopia de fuerza atómica (AFM), empleando concentraciones mayores de proteína $(21,6 \mu \mathrm{M})$. El patrón predominante, a pH 5,0, se observa como un background compuesto por 
material empaquetado de una altura de entre $5 \mathrm{a} 10 \mathrm{~nm}$ (observado en el fondo de la mica) (Fig. 5.2.2.D). También se observaron en algunos campos aislados estructuras tipo protofibrillas (Fig. 5.2.2.E). A pH 7,4 se observa muy poco material depositado y de menor tamaño (no mostrado).

Todos estos resultados sugieren que a $\mathrm{pH} 5,0$ se ve comprometido el equilibrio entre estructura nativa y la formación de agregados insolubles.

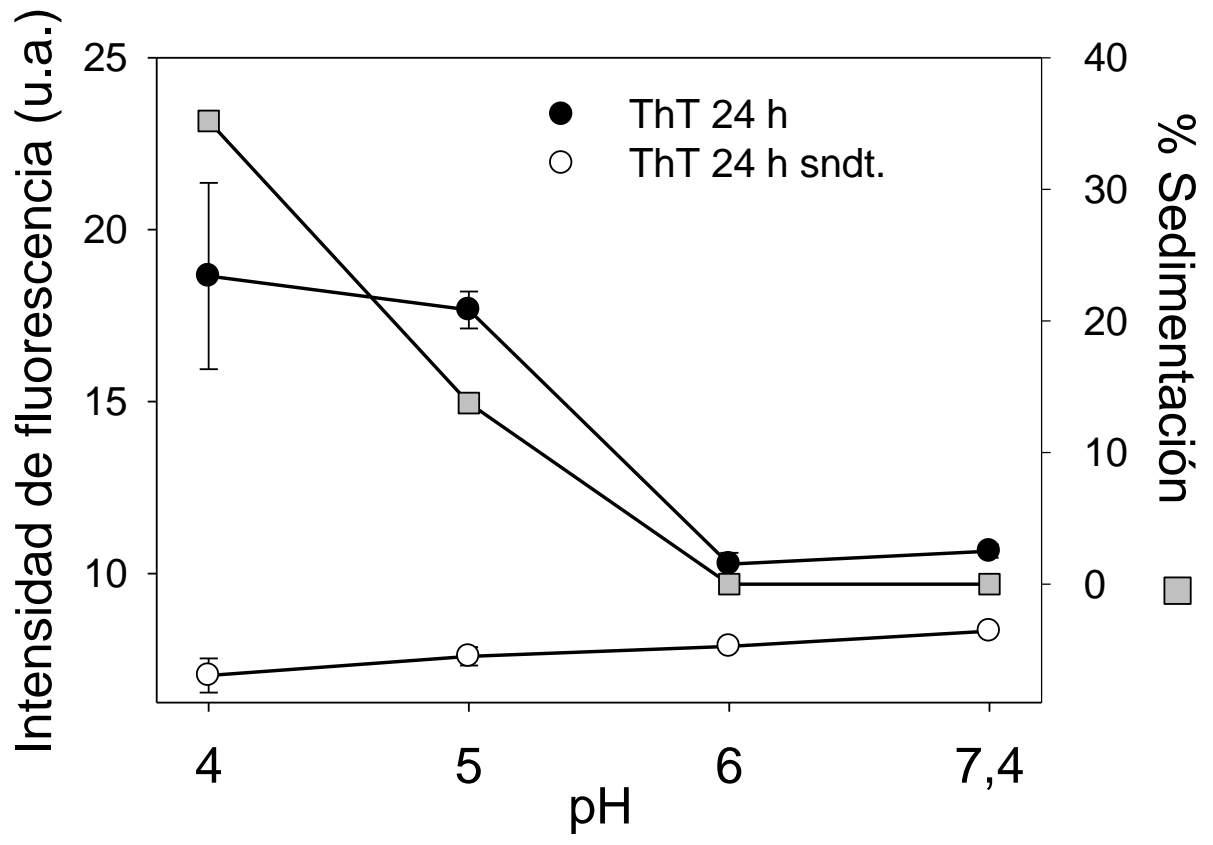

Figura 5.2.1. Unión a Tioflavina-T en función del pH. ApoA-I se incubó a $\mathrm{pH}$ 4,0; 5,0; 6,0 y 7,4 (buffer Mcllvaine) durante $24 \mathrm{~h}$ a $37^{\circ} \mathrm{C}$. La concentración final de proteína empleada fue 7,2 $\mu \mathrm{M}$. Luego se agregó ThT a cada muestra en una concentración final de $10 \mu \mathrm{M}$ y se leyó fluorescencia en un lector de placas (filtro excitación: $430 \mathrm{~nm}$, filtro emisión: $480 \mathrm{~nm}$ ) (círculos negros). Posteriormente las muestras se centrifugaron $(800 \times 9$ durante 10 minutos) y se leyó la fluorescencia remanente en el sobrenadante (círculos vacíos). El porcentaje de proteína sedimentada (cuadros grises) 

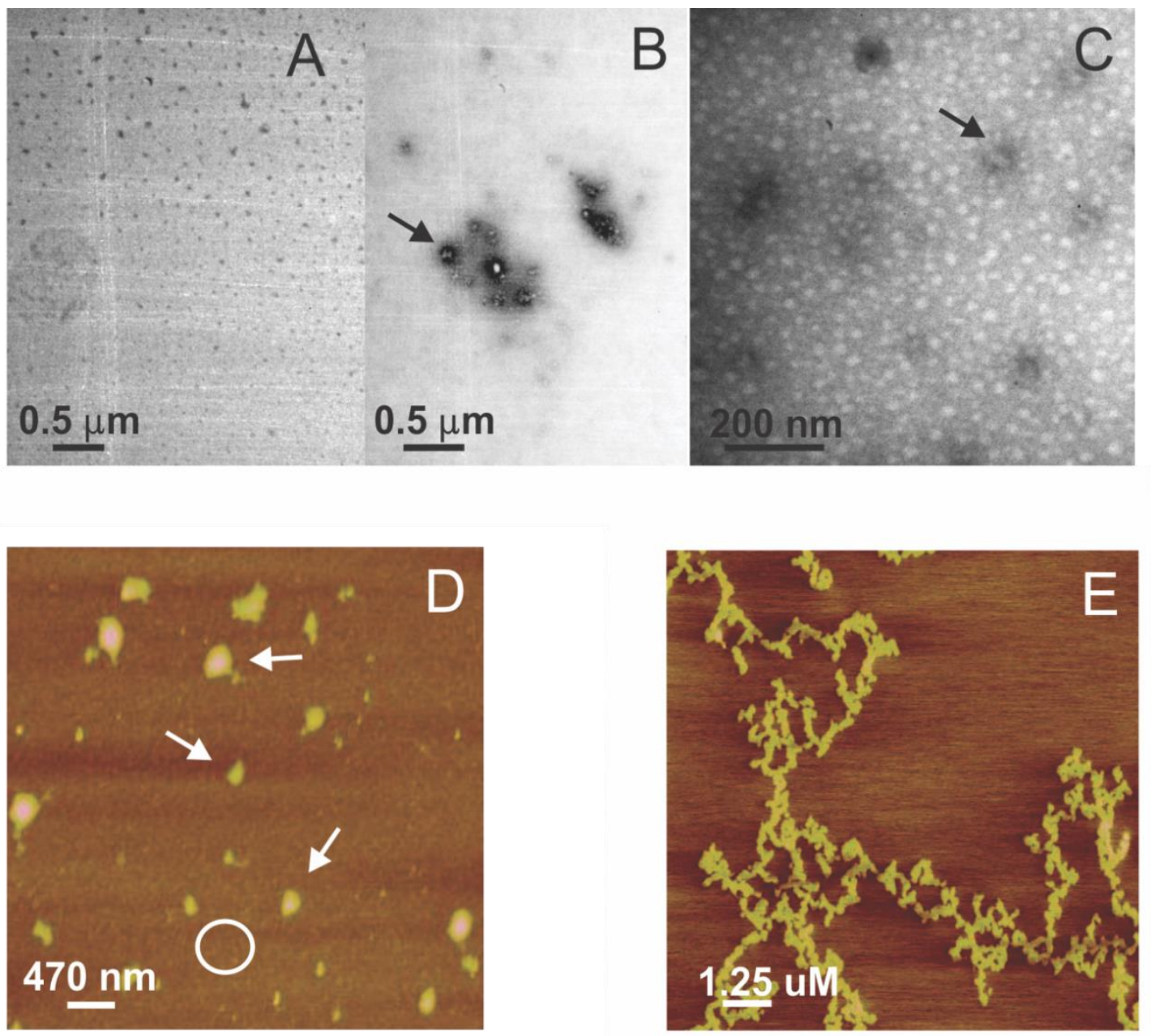

Figura 5.2.2. Morfología de los agregados de apoA-I inducidos por pH. LOS paneles A, B y C corresponden a imágenes de apoA-I wt obtenidas con microscopio electrónico, mientras que $D$ y $E$ son imágenes obtenidas empleando un microscopio de fuerza atómica. A) y B) ApoA-l, en una concentración de $14,4 \mu \mathrm{M}$, se incubaron a $37^{\circ} \mathrm{C}$ durante $24 \mathrm{~h}$ a pH 7,4 y pH 5,0 respectivamente, en $\mathbf{C}$ ) apoA-l, en igual concentración, fue incubada durante 48 días a pH 5,0. D) y E) ApoA-I $(21,6 \mu \mathrm{M})$ se incubo a $37^{\circ} \mathrm{C}$ durante $24 \mathrm{~h} \mathrm{a} \mathrm{pH}$ 5,0 , luego la muestra se colocó sobre mica. 


\subsection{Agregación inducida por unión a heparina.}

La heparina, el más estudiado de los GAGs, es un polímero cargado negativamente formado por unidades repetidas en forma regular del disacárido Lácido idurónico + N-acetil-D-glucosamina con un alto grado de sulfatación. Debido a su carácter negativo muchas proteínas interactúan con la heparina a través de interacciones electrostáticas. El uso de sales concentradas, para competir por las cargas negativas, y la sustitución de aminoácidos básicos dan cuenta de tales interacciones (Margalit y col., 1993). Se ha demostrado en varias ocasiones que los GAGs son capaces de inducir la formación de agregados tipo amiloides en distintos tipos de proteínas (Cohlberg y col., 2002; Kisilevsky, 2000), siendo reportado que apoA-I no une heparina (Harel y col., 1990) en condiciones de pH fisiológico. Teniendo en cuenta el carácter negativo de los GAGs, se ensayó la posibilidad de que el pH actúe modulando la capacidad de apoA-I de unirse a heparina, midiendo dispersión de luz (light scattering) a baja concentración de proteína. La dispersión de luz es proporcional al tamaño de las partículas en solución. ApoA-I (1,8 $\mu \mathrm{M})$ fue incubada a distintos $\mathrm{pH}$ con y sin heparina (relación proteína:heparina 2:1) durante $2 \mathrm{~h}$ a temperatura ambiente. En la figura 5.3.1.A se observa que en ausencia de heparina la dispersión de luz es baja en todos los pH ensayados durante este periodo de incubación. El comportamiento es distinto en presencia de heparina. A pH 7,4 y 6,0 la dispersión de luz fue baja y en el orden de la observada en ausencia de heparina, de acuerdo con la falta de sitios de unión de la apoA-I informada previamente. La acidificación del medio a pH 5,0 y especialmente a pH 4,0 causó un marcado incremente de dispersión, indicando que la heparina se une y promueve la agregación de apoA-I frente a un medio ácido.

En un experimento distinto se incubó la proteína en presencia o no de heparina durante $24 \mathrm{~h}$ a $37^{\circ} \mathrm{C}$ y se midió fluorescencia de Tht. También se realizaron incubaciones con $\mathrm{NaCl} 0,5 \mathrm{M}$ con la finalidad de que el sodio compita con la proteína por las cargas negativas de la heparina. En la figura 5.3.1.B se observa que a pH 5,0 y en presencia de heparina la proteína une significativamente más ThT mientras que este efecto es bloqueado en presencia 
de $\mathrm{NaCl}$. Estos datos sugieren que la interacción entre apoA-l y heparina se incrementa a pH ácido (por debajo del pl de la proteína) formando un complejo de tipo amiloide que se estabiliza por interacciones electrostáticas.
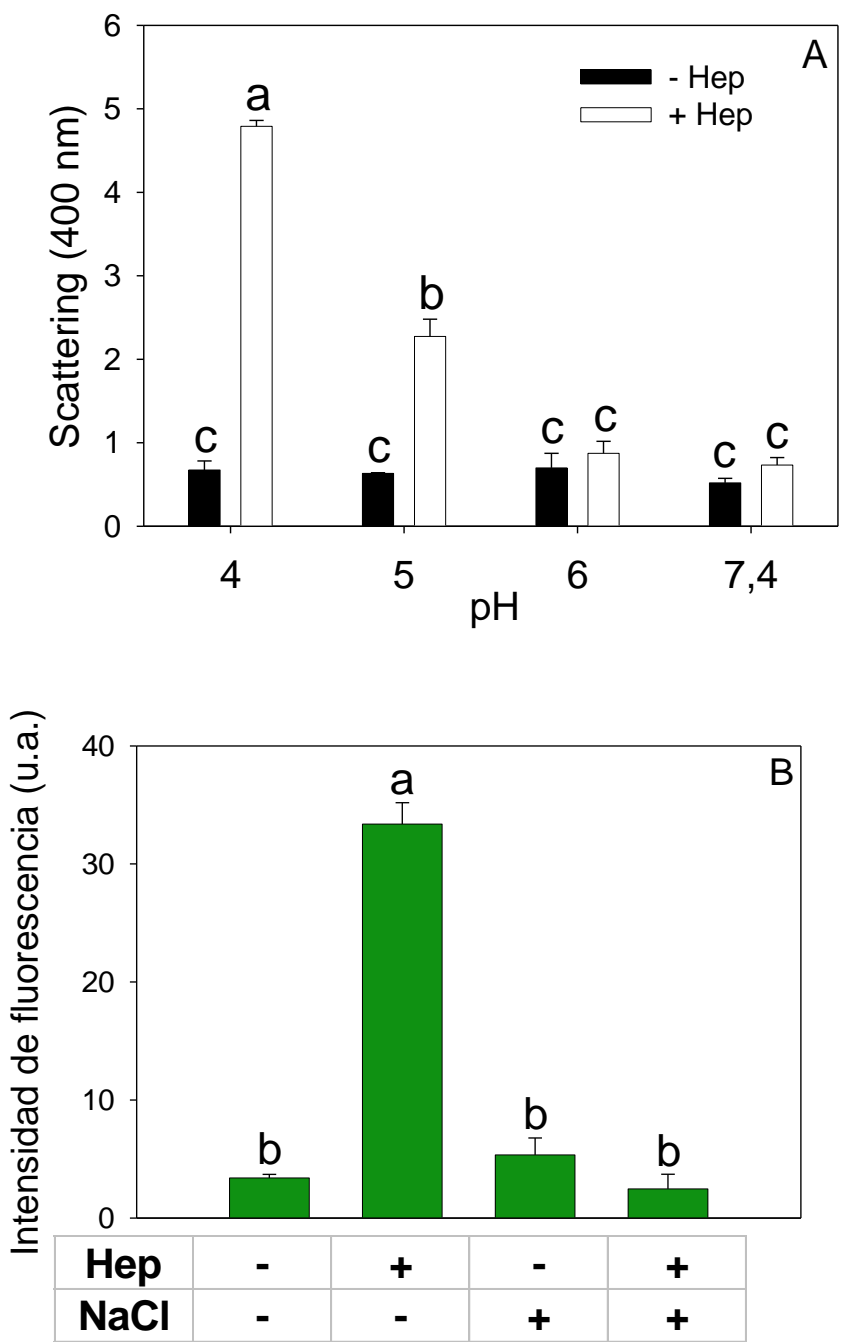

Figura 5.3.1. Unión a heparina en función del pH. A) ApoA-I $(1,8 \mu \mathrm{M})$ se incubo durante $2 \mathrm{~h}$ a diferentes valores de $\mathrm{pH}$ en presencia (barras negras) o ausencia (barras blancas) de heparina (relación molar heparina: proteína 2:1). La dispersión de luz (light scattering) se determinó a $400 \mathrm{~nm}$. B) ApoA-I (7,2 $\mu \mathrm{M})$ se incubo durante $24 \mathrm{~h}$ a $37^{\circ} \mathrm{C}$ a pH 5,0 en presencia $\mathrm{O}$ ausencia de heparina (relación molar heparina: proteína 2:1) ○ $500 \mathrm{mM}$ de $\mathrm{NaCl}$. Luego se agregó ThT a cada muestra en una concentración final de $10 \mu \mathrm{M}$ y se leyó fluorescencia en un lector de placas (filtro excitación: $430 \mathrm{~nm}$, filtro emisión: $480 \mathrm{~nm}$ ). Letras distintas implican diferencias significativas $(p<0,05)$. 


\subsection{Influencia de modificaciones proteolíticas y oxidativas sobre apoA-I respecto del plegamiento de la proteína.}

Los efectos de un ambiente pro-inflamatorio sobre apoA-I fueron simulados incubando a la proteína con neutrófilos previamente activados con TPA. Esta activación implica la acción de varias proteasas características de neutrófilos, como también la acción de radicales libres producidos durante el estallido oxidativo que se produce en respuesta a señales pro-inflamatorias. El ensayo resultó en la degradación parcial de apoA-I y una disminución en el peso molecular ( 22 kDa), respecto de la banda control sin neutrófilos correspondiente a apoA-I de 28 kDa (Fig. 5.4.1.A). Resulta interesante que los productos de apoA-I parcialmente degradados por neutrófilos unen significativamente más ThT que la proteína que no fue tratada con estas células (Fig. 5.4.1.B), sugiriendo que el procesamiento mediado por neutrófilos puede conducir a la formación de estructuras pro-amiloides.

Las metaloproteasas son secretadas al medio extracelular en la respuesta mediada por neutrófilos y macrófagos. En este sentido se ensayó la acción de la metaloproteasa 12 (MMP-12) sobre el procesamiento de apoA-I. Mediante western blot se observa la degradación de apoA-I por acción de MMP-12 detectando una pérdida en la intensidad de la banda, y curiosamente se observa la aparición de un péptidos de aproximadamente 11 kDa (Fig. 5.4.2.A). Sin embargo no se encontraron diferencias significativas en la unión de ThT respecto de los controles (Fig. 5.4.2.B). Por lo tanto los productos de esta reacción no parecen ser proamiloidogénicos, al menos en las concentraciones ensayadas. 
Figura 5.4.1. Acción de neutrófilos activados sobre el procesamiento proamilodogénico de apoA-I wt. ApoA-I (7,2 $\mu M)$ fue incubada en presencia de neutrófilos (PMN), previamente activados con TPA, a pH 7,4 y $37^{\circ} \mathrm{C}$ durante 1 h. A) Western blotting realizado con alícuotas del sobrenadante provenientes del ensayo, enfrentadas con anti-apoA-I policlonal. Lineas 1-3: apoA-I wt, líneas 46: apoA-I wt luego de ser tratada con neutrófilos activados. En todos los casos se sembró igual cantidad de proteína. B) Unión de ThT. Las muestras provenientes del ensayo fueron incubadas $24 \mathrm{~h}$ a $37^{\circ} \mathrm{C}$. Luego se agregó ThT a cada muestra en una concentración final de $10 \mu \mathrm{M}$ y se leyó fluorescencia en un lector de placas (filtro excitación: $430 \mathrm{~nm}$, filtro emisión: 480 $\mathrm{nm}$ ). Letras distintas implican diferencias significativas $(p<0,05)$.
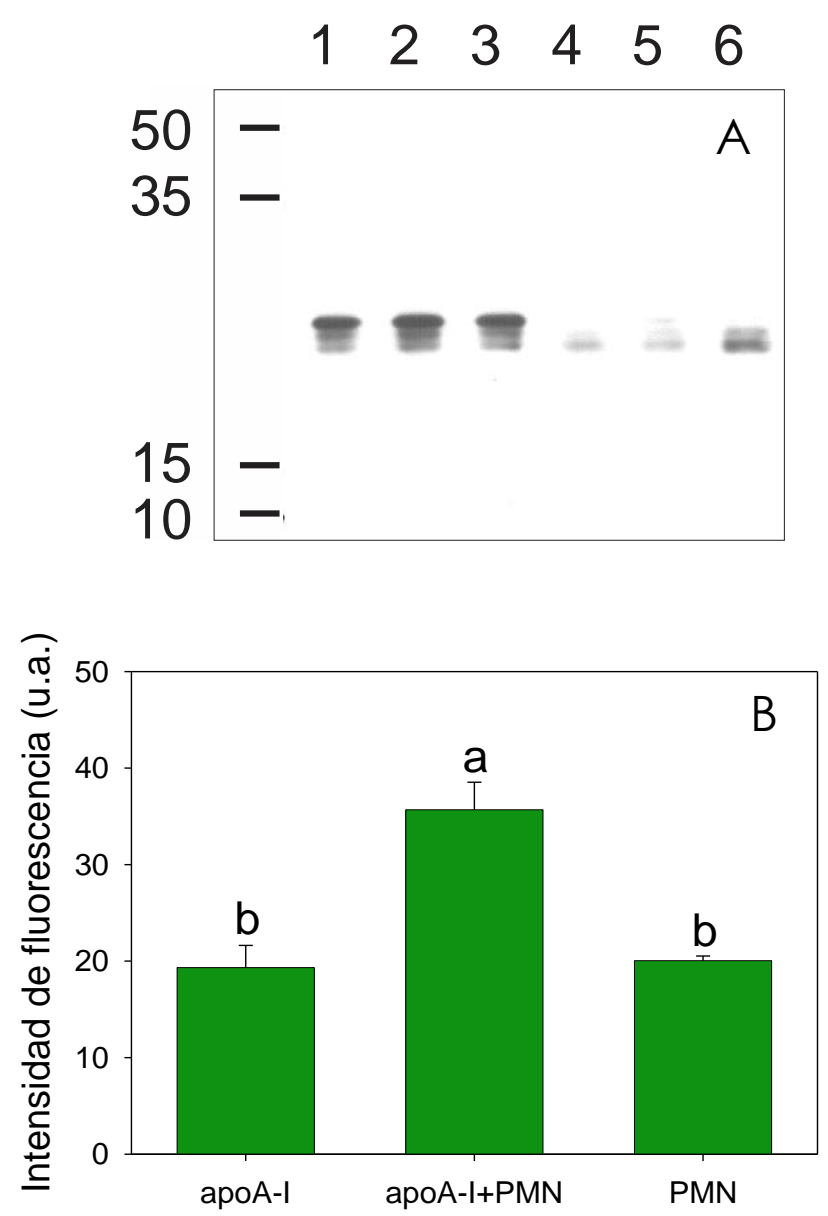
Figura 5.4.2. Efecto de la actividad proteolítica de MMP-12 sobre apoA-I wt. ApoA-I $(7,2 \mu \mathrm{M})$ fue incubada con MMP-12, a pH 7,4 y $37^{\circ} \mathrm{C}$ durante $1 \mathrm{~h}$. A) Western blotting realizado con antiapoA-I policlonal. Lineas 1-3: apoA-I wt, líneas 4-6: apoA-I wt luego de ser tratada con MMP-12. En todos los casos se sembró igual cantidad de proteína. B) Unión de ThT. Las muestras provenientes del ensayo fueron incubadas $24 \mathrm{~h}$ a $37{ }^{\circ} \mathrm{C}$. Luego se agregó ThT a cada muestra en una concentración final de $10 \mu \mathrm{M}$ y se leyó fluorescencia en un lector de placas (filtro excitación: $430 \mathrm{~nm}$, filtro emisión: $480 \mathrm{~nm})$.
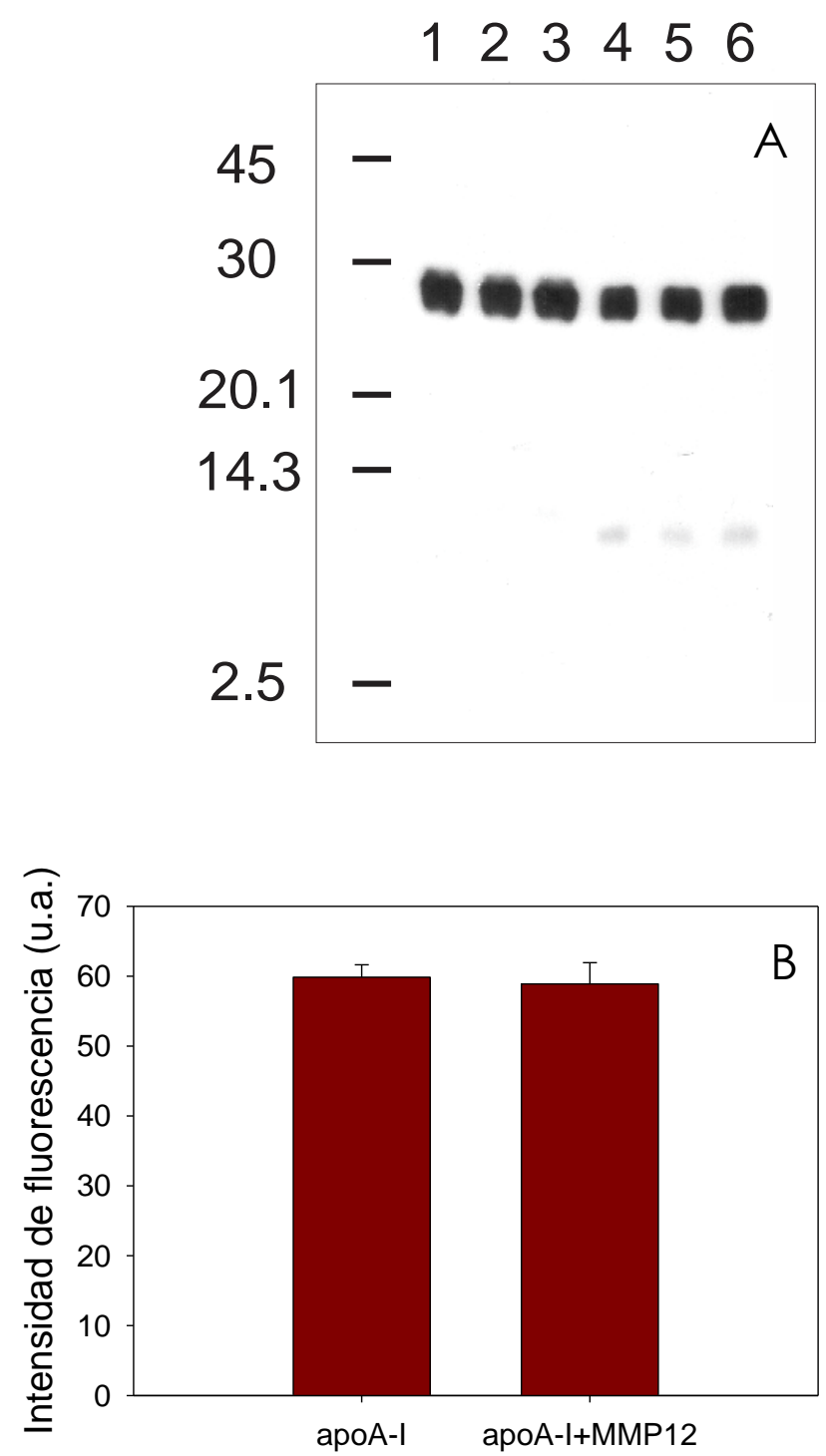
También se ensayó el efecto de la oxidación por acción del radical hipoclorito $(\mathrm{HClO})$. En los neutrófilos el $\mathrm{HClO}$ es producido por la enzima mieloperoxidasa durante el estallido oxidativo (Winrow y col., 1993). ApoA-I fue incubada en concentraciones crecientes de $\mathrm{HClO}$, y la reacción fue analizada por SDS-PAGE revelando por tinción con nitrato de plata y western blot. En la figura 5.4.3.A (panel inferior) se observa que la degradación de apoA-l ocurre en función de la concentración de $\mathrm{HClO}$. Luego estas muestras fueron incubadas con ThT para ver la formación de estructuras pro-amiloidogénicas. De manera interesante se puede notar que la unión de ThT no es lineal con la degradación mediada por $\mathrm{HClO}$, siendo los valores de fluorescencia más altos a 100 y $200 \mu \mathrm{M}$ y decrece a concentraciones mayores de $\mathrm{HClO}$, Esto indica la formación de un producto intermedio pro-amiloidogénico que se degrada posiblemente por proteólisis exhaustiva. En el western blot se observa la formación de estructuras de mayor tamaño (Fig. 5.4.3.B). Aunque no fue testeado se puede esperar que estas formaciones sean productos de entrecruzamientos (cross-linking) como resultado de la interacción entre residuos de aminoácidos oxidados. Los productos de oxidación fueron caracterizados por técnicas de microscopía. Para TEM, se incubó la proteína a una concentración final de $7,2 \mu \mathrm{M}$ con $100 \mu \mathrm{M}$ de $\mathrm{HClO}$ durante $24 \mathrm{~h}$ a $37^{\circ} \mathrm{C}$. En la figura 5.4.4.A se muestran los agregados que se hallaron en estas condiciones. Para profundizar los análisis estructurales se realizó AFM, incrementando la concentración de apoA-I a 21,4 $\mu \mathrm{M}$ e incubada a las mismas condiciones. En este caso se observó que, si bien predomina la presencia de oligómeros, puede detectarse la formación de estructuras tipo protofibrillas (Fig. 5.4.4 B y C). Esta evidencia soporta la idea de que la oxidación parcial de la proteína por $\mathrm{HClO}$ resulta en la formación de estructuras irreversibles de tipo amiloides.

Se realizaron experimentos para estudiar el efecto de la oxidación sobre la actividad biológica de apoA-I en la remoción de colesterol, empleando células $\mathrm{CHO}$ como modelo. Como es de esperar se observó una disminución en la capacidad de remover colesterol cuando la proteína se encuentra parcialmente oxidada (Fig. 5.4.5.). 

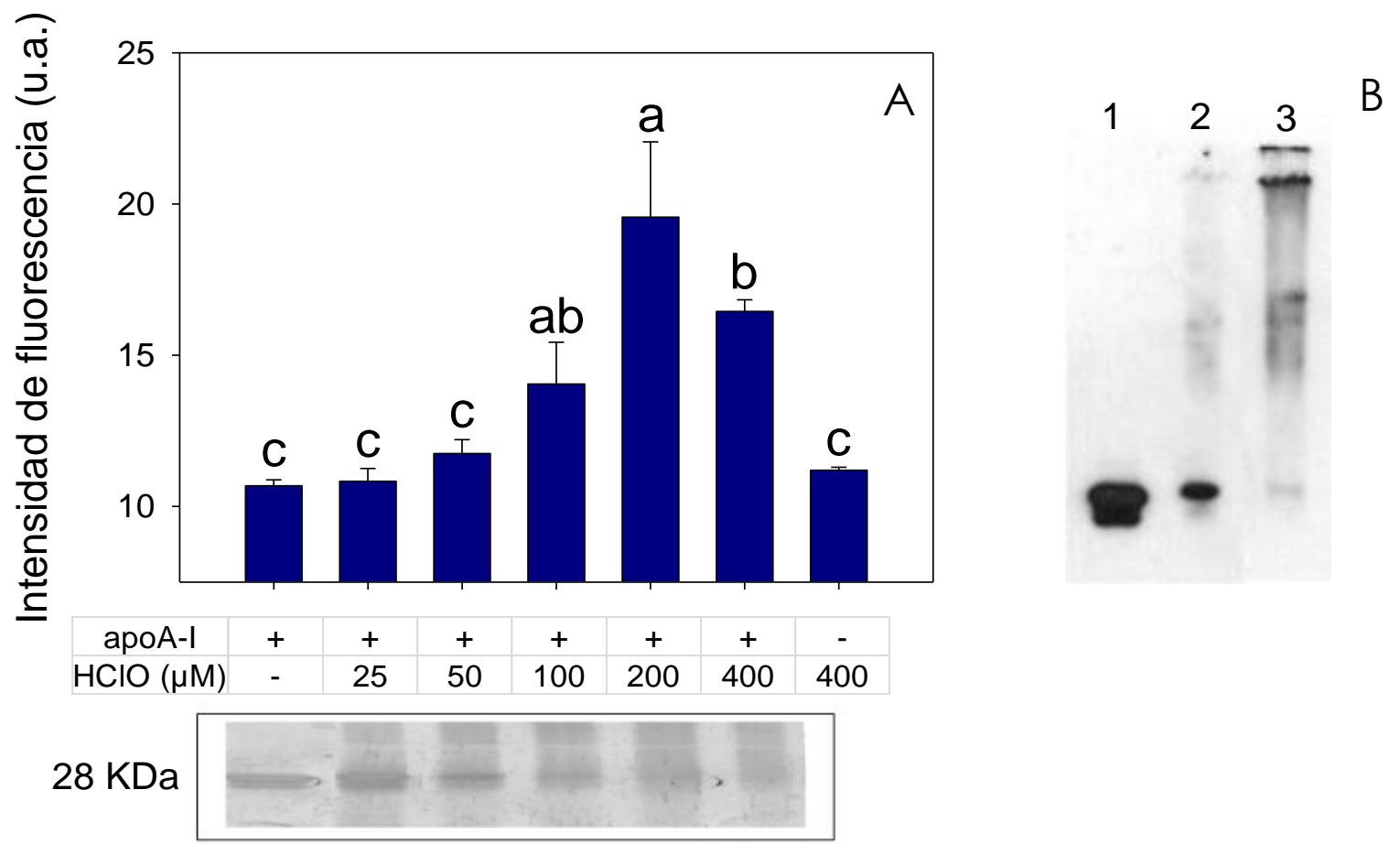

Figura 5.4.3. Efecto del $\mathrm{HClO}$ sobre apoA-I wt. ApoA-I wt $(3,6 \mu \mathrm{M})$ fue incubada con concentraciones crecientes de $\mathrm{HClO}$ durante 60 minutos a temperatura ambiente. A) $150 \mu \mathrm{l}$ de cada reacción fueron incubadas a $37^{\circ} \mathrm{C}$ durante $24 \mathrm{~h}$ y luego se agregó ThT en una una concentración final de $10 \mu \mathrm{M}$ y se determinó la fluorescencia en un lector de placas (filtro excitación: 430 nm, filtro emisión: 480 nm). Letras distintas implican diferencias significativas $(p<0,05)$. Panel de abajo: alícuotas de cada reacción se resolvieron en SDS-PAGE y se revelaron con tinción por plata. B) Western blot realizado con anti-apoA-I policlonal. Las líneas 1 a 3 corresponden a apoA-l incubada con 0, 25 y $200 \mu \mathrm{M}$ de $\mathrm{HClO}$ respectivamente.
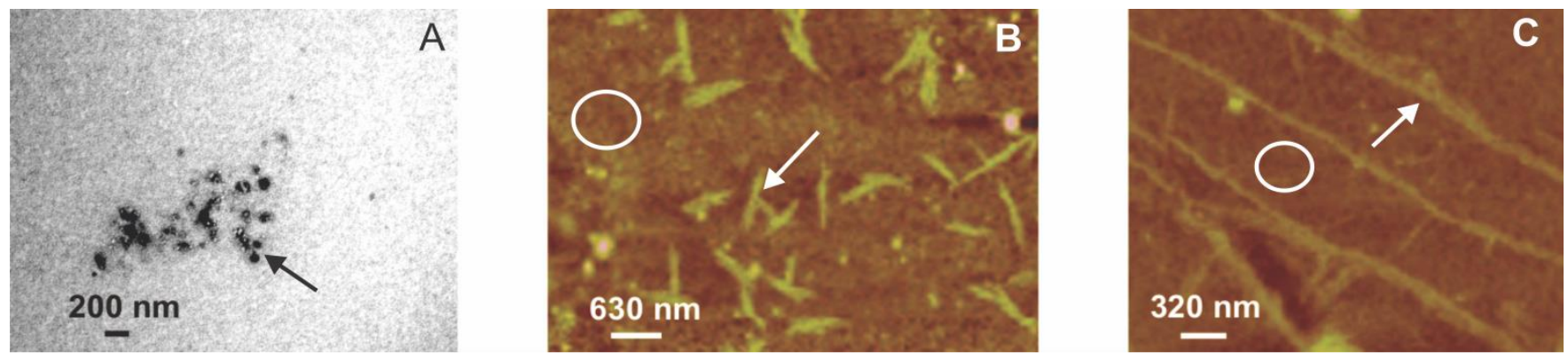

Figura 5.4.4. Morfología de los agregados de apoA-I wt inducidos por HClO. Las imágenes representan muestras de apoA-I wt tratadas con $\mathrm{HClO}$ y estudiadas por TEM (A) y AFM (B y C). A) ApoA-I $(7,2 \mu \mathrm{M})$ tratada con $100 \mu \mathrm{M}$ de $\mathrm{HClO}$, incubada durante $24 \mathrm{~h}$ a $37^{\circ} \mathrm{C}$. B) y C) ApoA-I $(21,6 \mu \mathrm{M})$ tratada con $100 \mu \mathrm{M}$ de $\mathrm{HClO}$, incubada durante $24 \mathrm{~h}$ a $37^{\circ} \mathrm{C}$. Las flechas indican las estructuras representativas. 


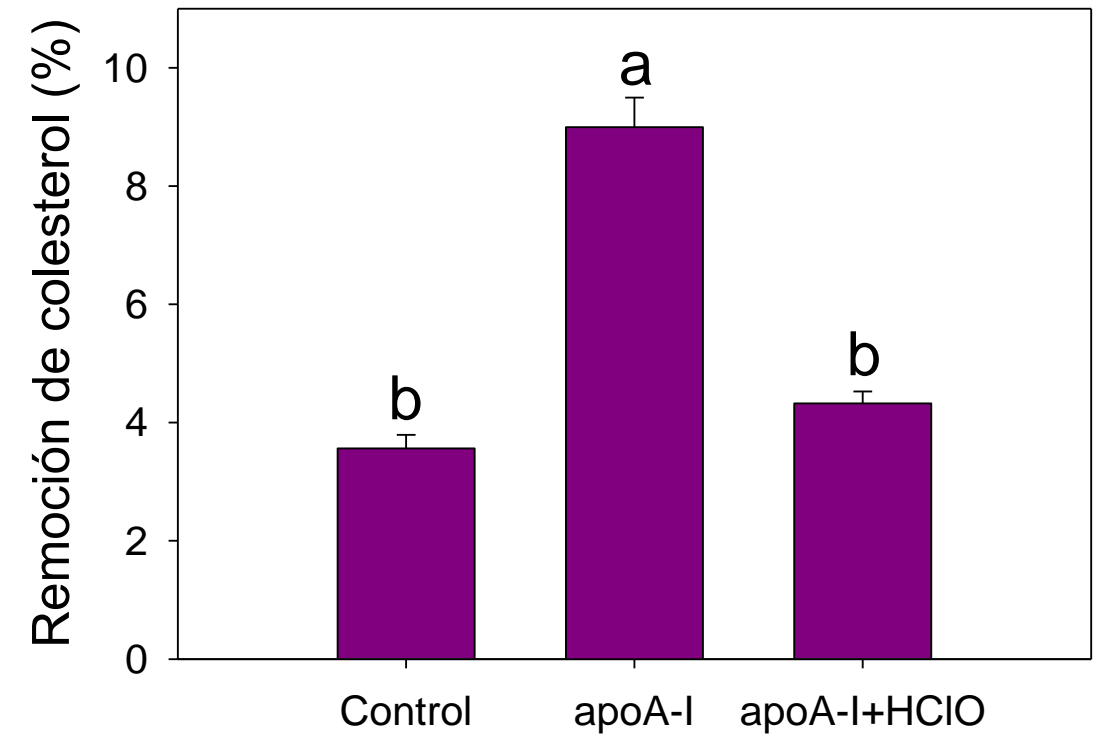

Figura 5.4.5. Remoción de colesterol mediada por apoA-I tratada con $\mathrm{HClO}$. Células $\mathrm{CHO}-\mathrm{K} 1$ fueron marcadas con colesterol tritiado e incubadas con apoA-I y apoA-I tratada con $\mathrm{HClO}(50 \mu \mathrm{M})$. Los resultados se expresan como el porcentaje de radioactividd removido por acción de la proteína. La columna control refiere a células incubadas en iguales condiciones pero en ausencia de proteína. Letras distintas implican diferencias significativas $(p<0,05)$. 


\section{Resultados II: Estudios estructurales y biológicos de las variantes de la apolipoproteína A-I Gly26Arg y Lys 107-0 implicadas en amiloidosis.}

6.1. Diferencias conformacionales entre apoA-I wt y las mutantes Gly26Arg y Lys 107-0.

Con la finalidad de estudiar si las variantes apoA-I Gly26Arg y apoA-I Lys 107-0 exhiben diferencias estructurales respecto de la proteína wt, se realizaron ensayos de fluorescencia. La fluorescencia intrínseca de apoA-I corresponde al promedio de la señal dada por los 4 Trp que posee (en posición 8, 50, 72 y 108), los cuales están preservados en ambas mutantes. El espectro de emisión de las dos mutantes muestra un ligero corrimiento de aproximadamente $2 \mathrm{~nm}$ hacia valores más altos de longitud de onda y un incremento significativo en la intensidad de fluorescencia (Tabla II, Fig. 6.1.1).

Para obtener más información del estado estructural de estas mutantes se realizaron ensayos de apagado ("quenching") con acrilamida. Del análisis de la fluorescencia en ausencia (FO) y en presencia (F) de concentraciones crecientes de acrilamida se puede obtener K (la constante de quenching) y fa (la fracción de residuos expuesta al solvente). Este análisis se observa en la Fig. 6.1.2. En ambas mutantes se observó una constante de quenching más alta que la obtenida con la proteína wł (Tabla II, Fig. 6.1.2.), indicando que los Trp en ambas mutantes se encuentran en promedio más expuestos al solvente que en la proteína wt. 
Figura 6.1.1. Fluorescencia intrínseca de las variantes de apoA-I. ApoA-I wt, Gly26Arg y Lys 107-0 se ensayaron a pH 7,4 (buffer citrato fosfato) a una concentración de 3,6 $\mu \mathrm{M}$. Las muestras se excitaron a $295 \mathrm{~nm}$ y el espectro de excitación se registró entre 310 y $370 \mathrm{~nm}$. En A) se grafica Intensidad de fluorescencia para las distintas muestras, y en B) los valores de fluorescencia normalizados.
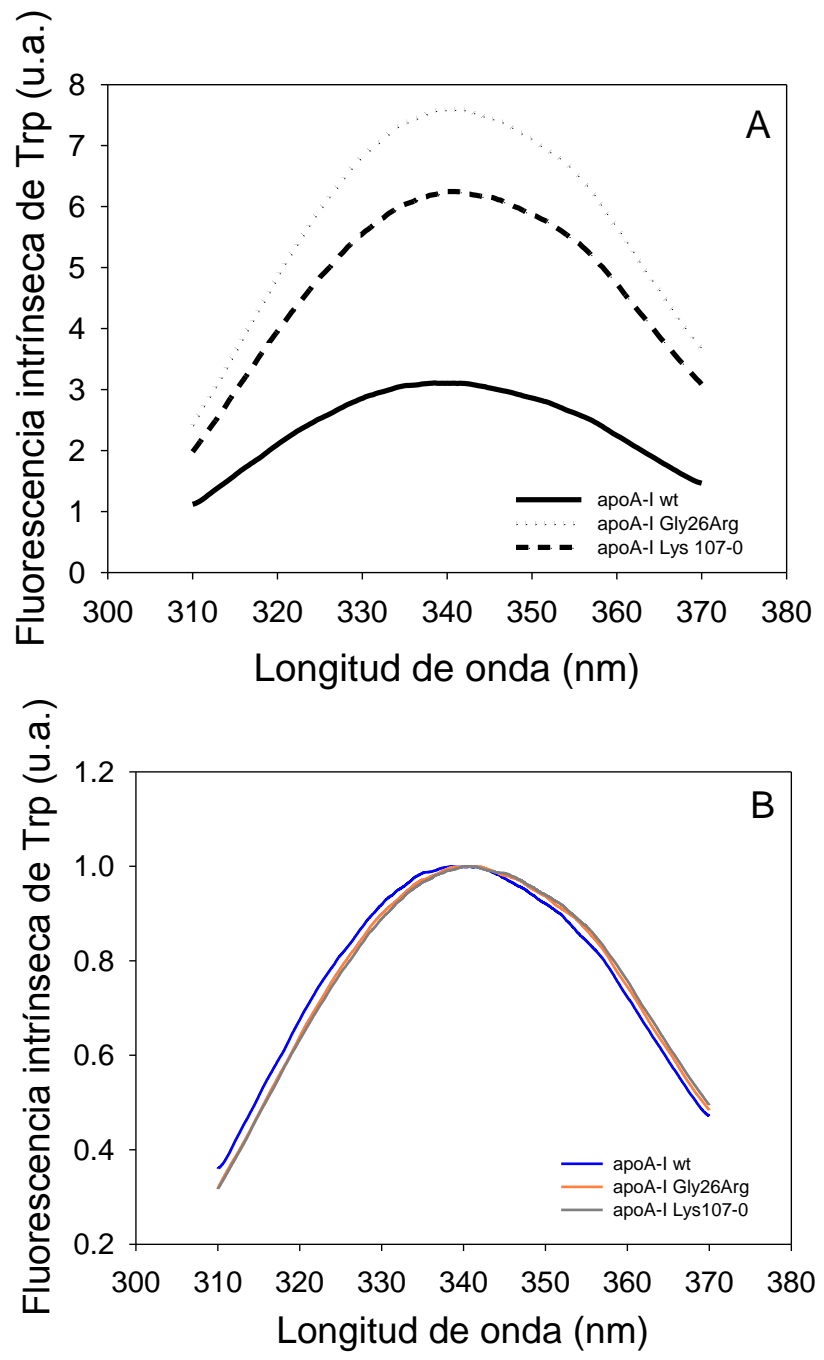

\begin{tabular}{|c|c|c|c|}
\hline & wt & Gly26Arg & Lys107-0 \\
\hline$\lambda$ max Trp (nm) & $338,0 \pm 2,0$ & $340,0 \pm 2,0$ & $340,5 \pm 2,0$ \\
\hline $\begin{array}{c}\Delta \mathrm{G}^{\circ} \text { desnat. } \\
(\mathrm{Kcal} / \mathrm{mol})\end{array}$ & $2,53 \pm 0,07$ & $1,54 \pm 0,06$ & $1,91 \pm 0,19$ \\
\hline $1 / 2[\mathrm{GndHCl}](\mathrm{M})$ & $1,4 \pm 0,2$ & $1,0 \pm 0,3$ & $1,2 \pm 0,3$ \\
\hline$K\left(\mathrm{M}^{-1}\right)$ & $5,26 \pm 0,3$ & $7,90 \pm 0,41$ & $6,54 \pm 0,32$ \\
\hline
\end{tabular}

Tabla II. Estabilidad y propiedades espectrales de las variantes de apoA-I a 3,6 $\mu \mathrm{M}$ y $\mathrm{pH}$ fisiológico. 

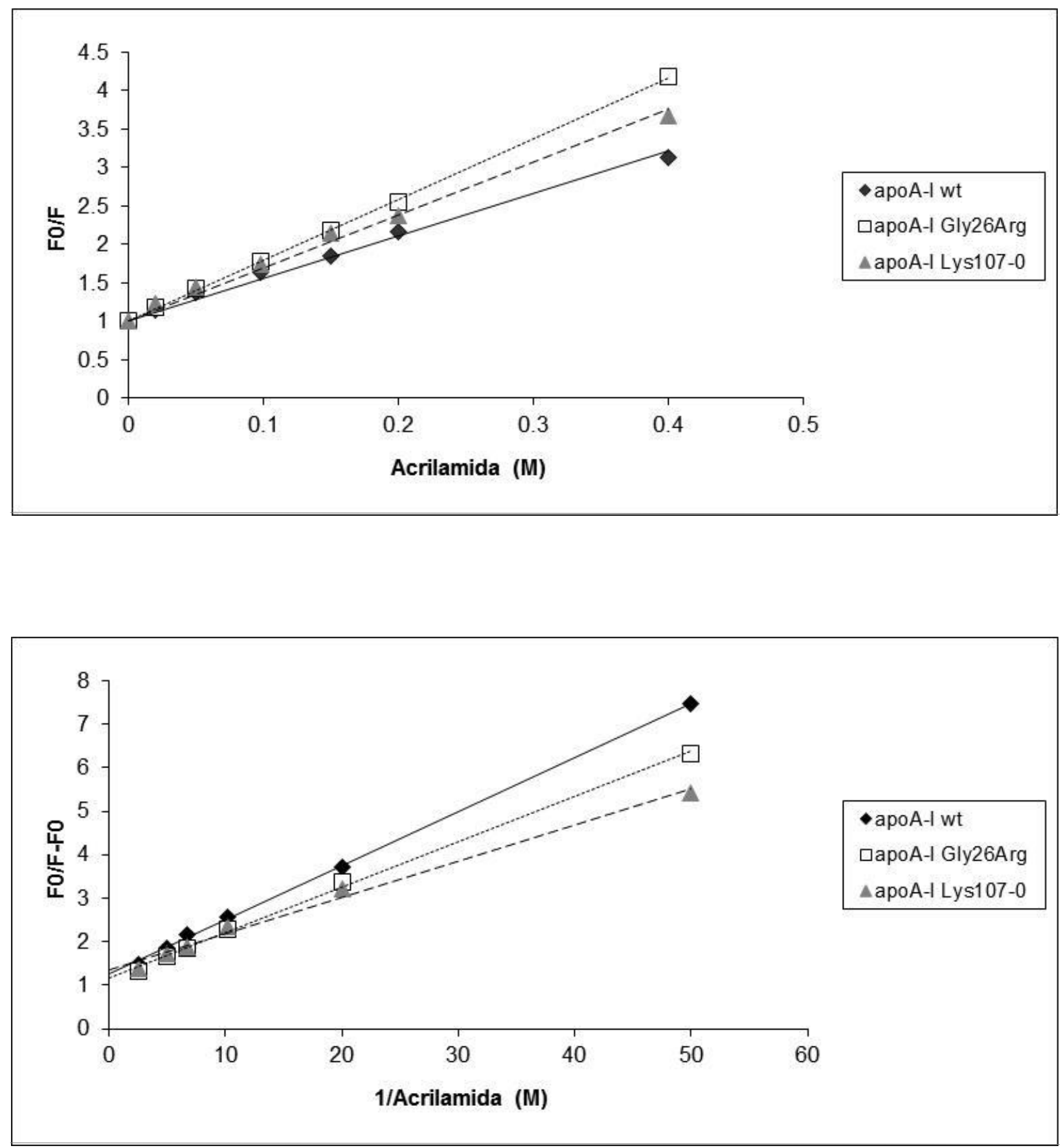

Figura. 6.1.2. Quenching con acrilamida. A) ApoA-I wt, Gly26Arg y Lys 107-0 se incubaron con concentraciones crecientes de acrilamida. Los ensayos se realizaron a pH 7,4 (buffer de Mc Ilvaine). La concentración final de proteína empleada fue 7,2 $\mu \mathrm{M}$. Las muestras se excitaron a $295 \mathrm{~nm}$ y el espectro de excitación se registró entre 305 y $375 \mathrm{~nm}$. El centro de masa se utilizó para calcular la proporción Fo/F. Fo: intensidad inicial en ausencia de acrilamida; F: intensidad correspondiente a cada concentración de acrilamida. B) Transformación de Stern-Volmer. 
Para evaluar variaciones en los bolsillos hidrofóbicos y el estado de glóbulo fundido se ensayó la unión de bis-ANS. La titulación de las proteínas con bis-ANS resultó en una unión del tipo no cooperativa. La fluorescencia asociada a la unión de la sonda a la proteína fue similar en ambas mutantes y significativamente mayor respecto de la unión en la proteína wt. Un leve corrimiento del espectro hacia el rojo se observó para la unión de bis-ANS en la proteína wt respecto de las variantes (Fig 6.1.3 inserto). Sin embargo, y dado el sensible corrimiento ( 50 nm) que puede experimentar esta sonda en base al entorno en el que se encuentra (Hawe y col., 2008), el leve corrimiento detectado sugiere que el aumento en la fluorescencia se debe a más moléculas de la sonda unidas por proteína (Fig. 6.1.3.) pero a un entorno similar.

El análisis de estos resultados en conjunto sugiere que una mutación puntual, ya sea en el caso de la sustitución de Gly por Arg en posición 26, o la deleción de la Lys 107, produce cambios en la conformación del dominio N-terminal de apoA-I (donde se encuentran los Trp) que resultan en una mayor exposición relativa de estos residuos y en una estructura con mayor número de bolsillos hidrofóbicos 0 , al menos, más permeables al bis-ANS.

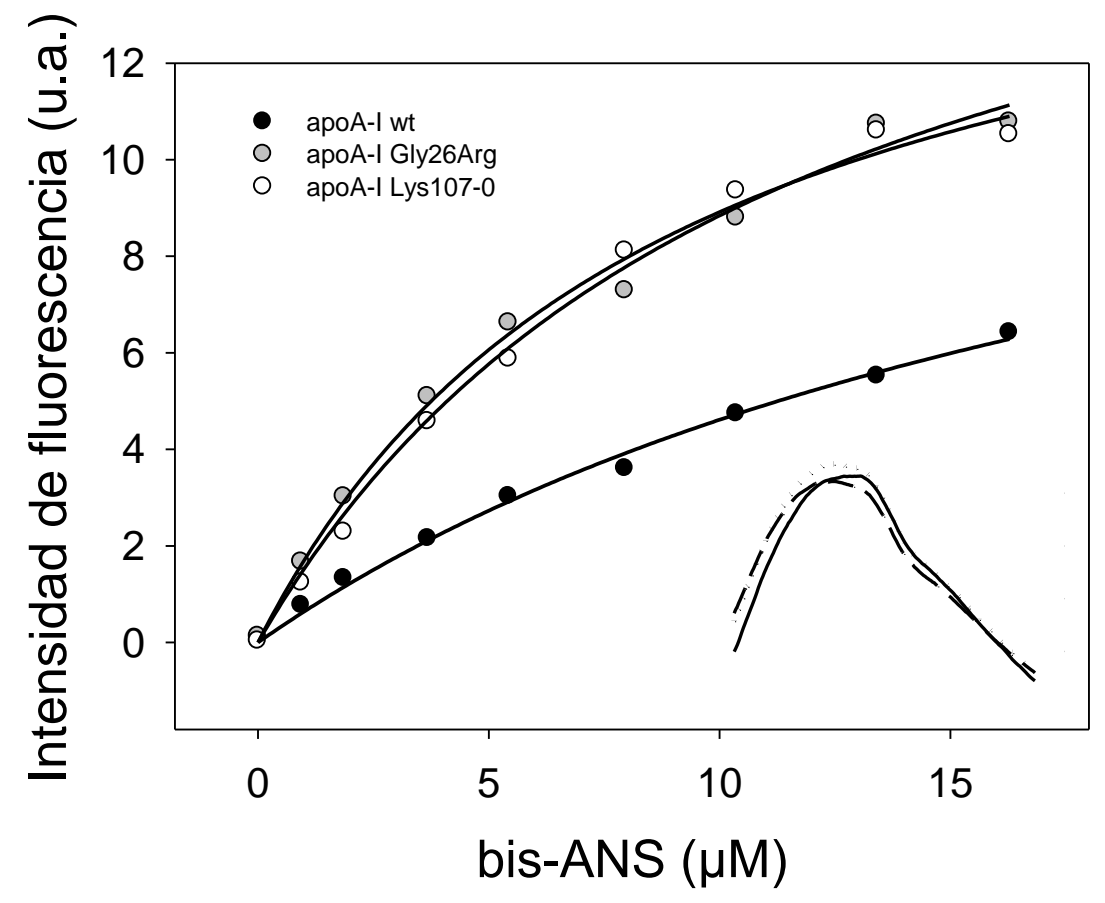

Figura. 6.1.3. Titulación con bis-ANS. ApoA-I wt, Gly26Arg y Lys 107-0 se ensayaron en pH 7,4 (buffer citrato fosfato) a una concentración de 3,6 $\mu \mathrm{M}$ y se titularon con bis-ANS hasta una concentración final de $16 \mu \mathrm{M}$. La sonda se excitó a $395 \mathrm{~nm}$ y registró en valor del máximo de emisión. En el inserto se muestra el espectro de excitación entre 450 y $550 \mathrm{~nm}$ para wt (línea continua), Lys107-0 (con trazos) y Gly26Arg (punteada), respectivamente. 


\subsection{Estabilidad y plegamiento de las variantes de apoA-I en estudio.}

De igual modo que ocurre con apoA-I wt a pH fisiológico, las dos mutantes también presentan un patrón de desnaturalización cooperativo definido por dos estados. El patrón de desnaturalización de ambas mutantes indica una estabilidad menor en comparación con la proteína wt, reflejado en los valores más bajos de $\Delta \mathrm{G}^{0}$ (siendo 1,91 y $1,54 \mathrm{kcal} / \mathrm{mol}$ para Gly26Arg y Lys $107-0$ respectivamente), y el valor de [GndHCl]1² (Tabla II). Más aún, las curvas sigmoideas menos pronunciadas reflejan una disminución en el desplegamiento cooperativo de las dos variantes (Fig. 6.2.1).

La estabilidad conformacional de las proteínas también fue estudiada midiendo la fluorescencia de bis-ANS en presencia de concentraciones crecientes de $\mathrm{GndHCl}$. Para esto, las tres proteínas fueron incubadas con bis-ANS en una relación molar 5:1 (proteína: sonda). En la figura 6.2.2 se observa que la fluorescencia decrece abruptamente con el incremento de la concentración de GndHCl. Este comportamiento confirma el estado de glóbulo fundido de las proteínas en estado nativo (ya que éste es el estado de mayor accesibilidad para el bis-ANS (Munishkina y col., 2007)), el que comienza a desorganizarse a bajas concentraciones de $\mathrm{GndHCl}$. Este comportamiento fue similar en apoA-I wt y las dos mutantes, en los tres casos la [GndHCl] $1 \frac{2}{2}$ aparente se encuentra por debajo de $0,5 \mathrm{M}$.

Los resultados demuestran que los arreglos espaciales de la proteína (monitoreados por bis-ANS) se pierden a menores concentraciones de $\mathrm{GndHCl}$ que las requeridas para producir el desplegamiento global de la estructura secundaria de la proteína (monitoreada por fluorescencia de Trp). Este se ve claramente cuando se superponen los perfiles de desnaturalización (Fig. 6.2.3). Este resultado es similar para la proteína wt y las dos mutantes. 


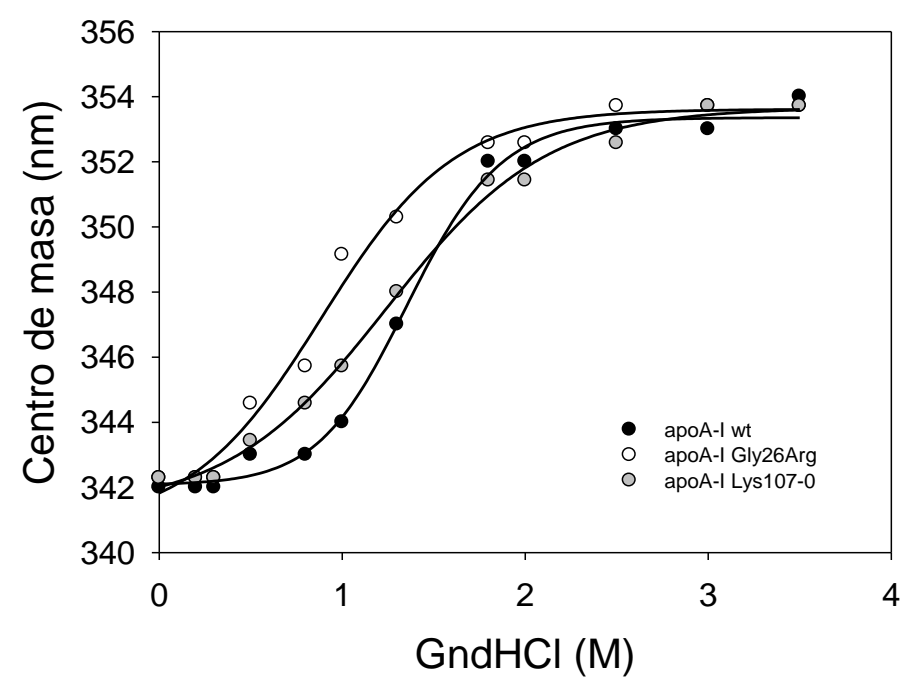

Figura. 6.2.1. Desnaturalización química de apoA-I wt mediada por GndHCI. LOS centros de masa de los espectros de fluorescencia intrínseca de apoA-I se graficaron en función de la concentración de $\mathrm{GndHCl}$. La concentración final de las proteínas empleadas fue $3,6 \mu \mathrm{M}$ en todos los casos. Los ensayos se realizaron a pH 7,4. Las muestras se excitaron a $295 \mathrm{~nm}$ y el espectro de emisión se registró entre 310 y $420 \mathrm{~nm}$. Los datos se ajustaron en base a un modelo sigmoideo.

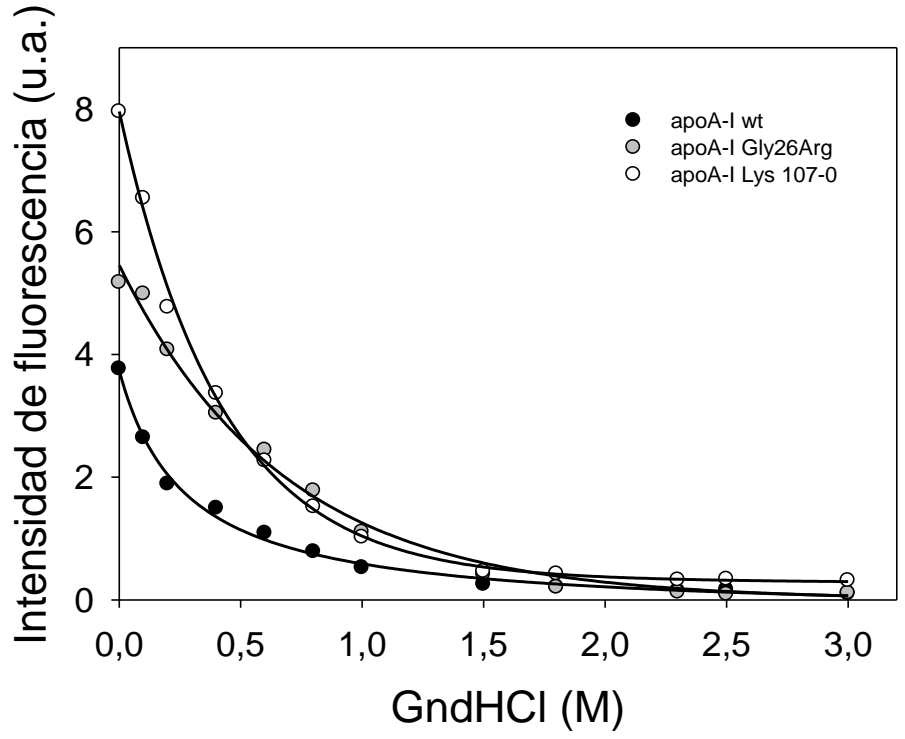

Figura. 6.2.2. Unión de bis-ANS en función de la concentración de GndHCl. Las proteínas (concentración final 3,6 $\mu \mathrm{M} ; \mathrm{pH} 7,4$ ) se incubaron con bis-ANS en una relación molar 5:1 proteína:sonda y se midió la fluorescencia en función de la concentración de GndHCl. Las muestras se excitaron a $395 \mathrm{~nm}$ y el espectro de emisión se registró entre 450 y $550 \mathrm{~nm}$. Se grafica los valores máximos para cada caso. 


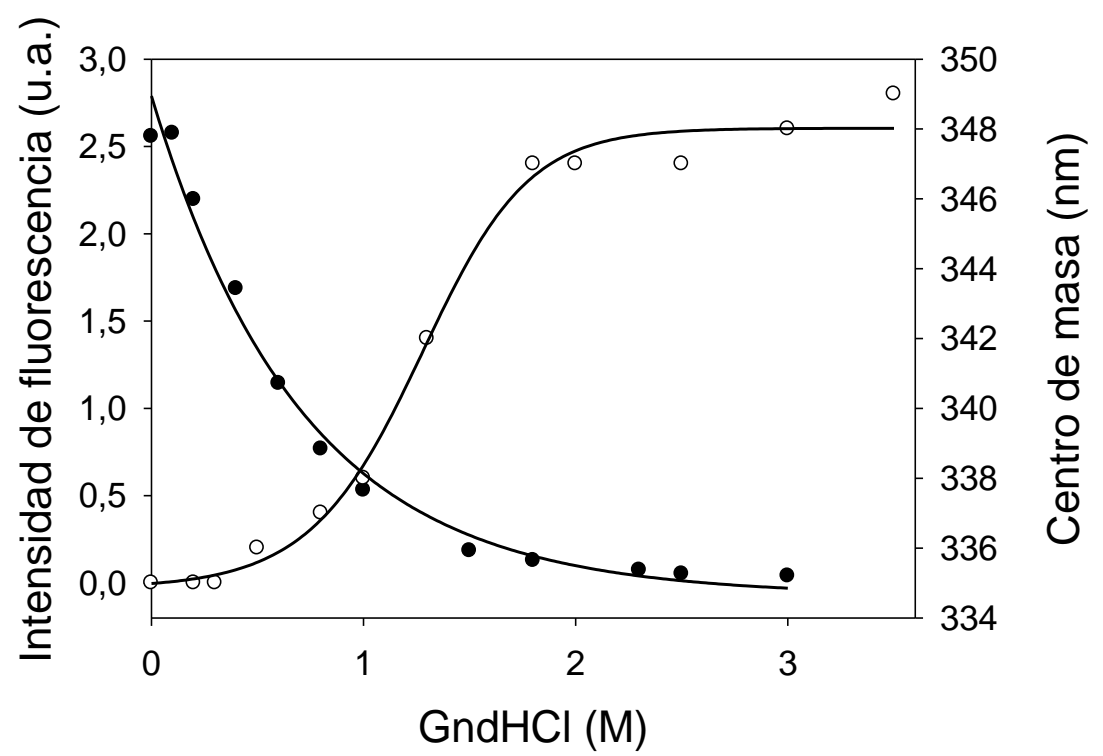

Figura. 6.2.3. Desnaturalización química mediada por $\mathrm{GndHCl}$ seguida por fluorescencia intrínseca de Trp (círculos vacíos, eje y a la derecha) y por unión de bis-ANS (círculos llenos, eje y a la izquierda). Las curvas corresponden a los datos de los gráficos de las figuras 6.2.1 y 6.2.2 para apoA-I wt.

\subsection{Caracterización morfológica de los agregados.}

Por microscopía de fuerza atómica (AFM) se caracterizó la morfología de los agregados formados cuando las distintas variantes proteicas, en una concentración de $21,6 \mu \mathrm{M}$, fueron incubadas $24 \mathrm{~h}$ a $37^{\circ} \mathrm{C}$ en $\mathrm{pH} 7$,4. En todos los casos se observó un patrón de pequeños agregados de tipo oligómeros (Fig. 6.3.1). A fin de caracterizar el tamaño de los mismos, se midió la altura de 100 agregados mediante software asociado al microscopio (Nanoscope 7.30), y se obtuvo un histograma correspondiente a cada imagen con la distribución de alturas y frecuencia de dichos agregados. Del análisis se desprende que apoA-I wł se caracteriza por presentar oligómeros que presentan cierta homogeneidad en su forma y una altura que va desde los 4 a los $14 \mathrm{~nm}$ siendo las formaciones de $10 \mathrm{~nm}$ de alto las que se presentan con mayor frecuencia. En el caso de la variante Gly26Arg se observan agregados algo menos homogéneos que los que se obtiene con la proteína wt, con una altura de entre 2 y $12 \mathrm{~nm}$. Al igual que en el primer caso, los agregados de $10 \mathrm{~nm}$ de alto son los de mayor frecuencia. Por último, en la variante Lys107-0 los agregados son bastante más heterogéneos en forma 
respecto de lo observado en las otras dos muestras con una altura máxima de aproximadamente $30 \mathrm{~nm}$ y aún más altas que no fueron representadas, lo cual es considerablemente mayor a lo obtenido con las otras dos proteínas, y los de menor tamaño son de $6 \mathrm{~nm}$. Sin embargo predominan los agregados de entre 8 y $14 \mathrm{~nm}$. En la figura 6.3.1, como inserto en los histogramas, se muestran estructuras halladas en observaciones de microscopía electrónica con tinción negativa. Dado que Lagerstedt y colaboradores habían descrito estructuras en forma de anillo para Gly26Arg mediante TEM (Lagerstedt y col., 2007), nosotros usamos este tipo de microscopía para hacer una análisis exhaustivo de las especies presentes en las muestras. Los insertos en la figura 6.3.1. indican hallazgos encontrados ocasionalmente, como fibras desorganizadas o protofibras, sin embargo las muestras fueron nuevamente representadas por oligómeros coincidente con las observaciones de AFM. Estos oligómeros son muy similares a las descriptas por Sandberg y col. para los oligómeros formados por el péptido $\beta$-amiloide (Sandberg y col., 2010). Sería probable que el empleo de tiempos de incubación más prolongados (más de una semana) y mayores concentraciones de proteína (2 $\mathrm{mg} / \mathrm{mL}$ ) hayan favorecido la formación y depósito de distintos agregados en los experimentos de Lagerstedt. 
A)
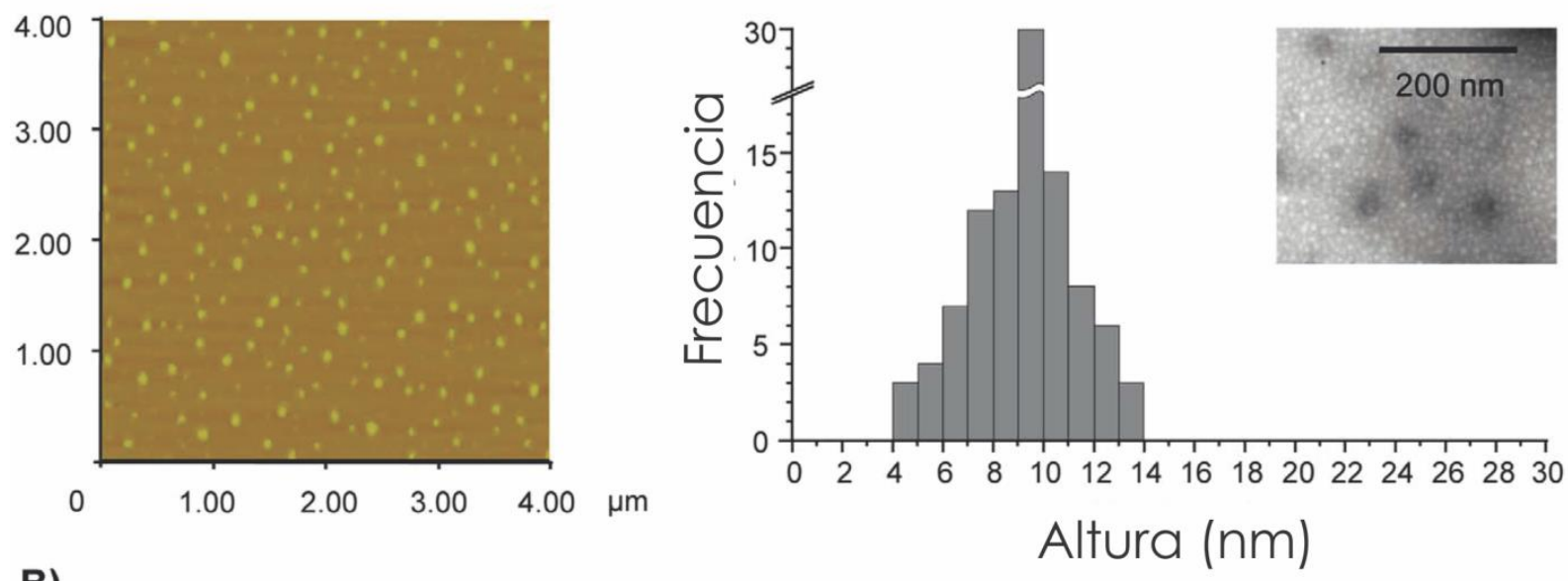

B)

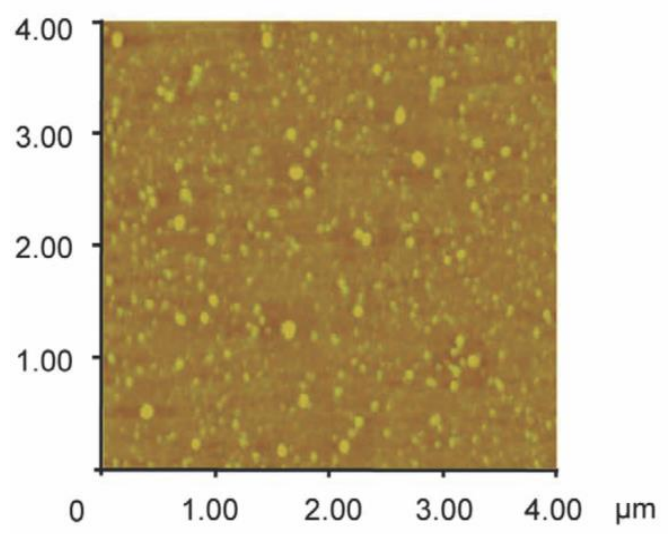

C)
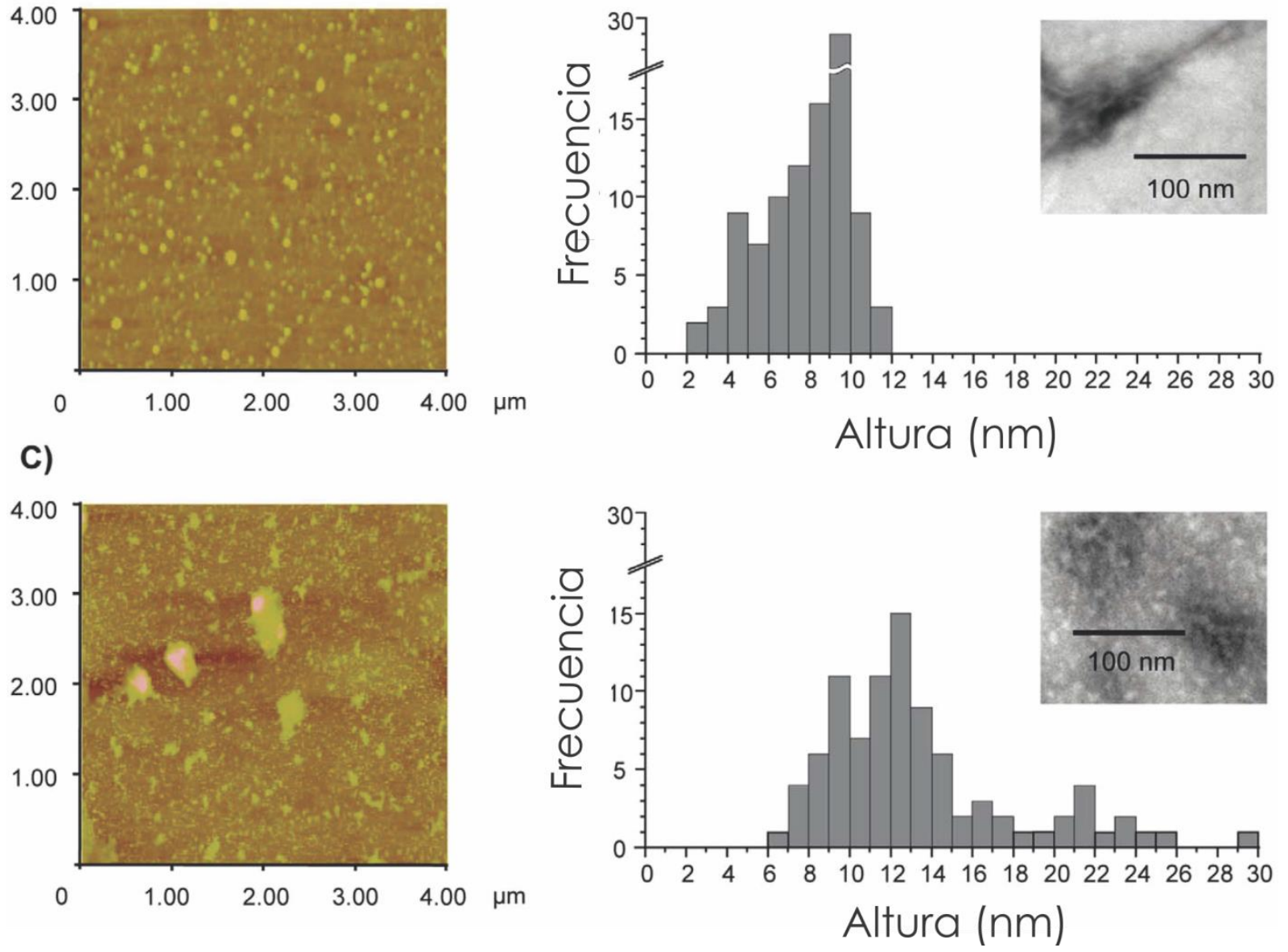

Figura. 6.3.1. Caracterización morfológica de los agregados de apoA-I por AFM. ApoA-I wt, Gly26Arg y Lys 107-0 en una concentración de 21,6 $\mu \mathrm{M}$, fueron incubadas durante 24 h en buffer citrato fosfato $\mathrm{pH} 7,4$ a $37^{\circ} \mathrm{C}$. Luego las muestras fueron cargadas en un soporte de mica y observadas en un microscopio de fuerza atómica. La distribución del tamaño de los agregados se expresa en forma de histograma. El inserto dentro del histograma muestra agregados ocasionales revelados con tinción negativa y observados en microscopio electrónico. 


\subsection{Influencia del ambiente pro-inflamatorio sobre el} plegamiento de las variantes de apoA-I Gly26Arg y Lys 107-0.

Las tres proteínas fueron incubadas con neutrófilos previamente activados durante 1 hora, luego las células fueron sedimentadas por centrifugación suave, y por último los productos de la reacción se incubaron $24 \mathrm{~h}$ a $37^{\circ} \mathrm{C}$ para finalmente medir unión de Tht. Como era de esperar, y al igual que ocurrió previamente con la proteína wt, en todos los casos las proteínas fueron parcialmente degradadas (Fig. 6.4.1.A), resultando en una producto que une más ThT respecto de la proteína sin tratar (Fig. 6.4.1.B). En algunos experimentos la degradación fue más drástica que en otros. Con la finalidad de comparar la susceptibilidad de las variantes para la formación de agregados amiloides respecto a la wt, los resultados se expresaron como la proporción de la fluorescencia de ThT de las proteínas tratadas sobre las proteínas sin tratar con PMN. No se observaron diferencias entre la variante Gly26Arg y la proteína wt. Por su parte la mutante Lys 107-0 unió significativamente más ThT luego de ser tratada con PMN (valor aproximado a 3) y la relación versus la variante sin tratar expresada en el gráfico es considerablemente mayor respecto de las otras dos proteínas (Fig. 6.4.1.B).

Las proteínas también se incubaron en presencia de MMP-12 a fin de evaluar si los productos resultantes de la proteólisis forman estructuras de tipo amiloides luego de ser incubadas $24 \mathrm{~h}$ a $37^{\circ} \mathrm{C}$. En el western blot se observa que tanto proteína wt (como ya se había mencionado previamente) como las dos mutantes son sensibles a la proteólisis por MMP-12, y en todos los casos se observa un fragmento de aproximadamente $11 \mathrm{kDa}$. Para determinar si estos productos forman estructuras tipo amiloide, se midió la fluorescencia de ThT luego de ser incubados durante $24 \mathrm{~h}$ a $37^{\circ} \mathrm{C}$. Los valores se expresaron, en este caso también, como la proporción de proteína tratada versus proteína sin tratar. No se observaron diferencias significativas en ninguno de los tres casos. Este resultado sugiere que los la actividad proteolítica de MMP-12 por si sola no es condición para generar estructuras amiloides, al menos en las condiciones ensayadas. 
Figura. 6.4.1. Acción de neutrófilos activados sobre el procesamiento proamilodogénico de apoA-I Gly26Arg y Lys 107-0. ApoA-I wt, Gly26Arg y Lys107-0 $(7,2 \mu \mathrm{M})$ fueron incubadas en presencia de neutrófilos (PMN), previamente activados con TPA, a pH 7,4 y $37^{\circ} \mathrm{C}$ durante 1 h. A) Western blot realizado con alícuotas del sobrenadante proveniente del ensayo, enfrentadas con anti-apoA-I policlonal. En todos los casos se sembró igual cantidad de proteína. B) Unión de ThT. Las muestras provenientes del ensayo fueron incubadas 24 h a $37^{\circ} \mathrm{C}$. Luego se agregó ThT a cada muestra en una concentración final de 10 $\mu M$ y se leyó fluorescencia en un lector de placas (filtro excitación: $430 \mathrm{~nm}$, filtro emisión: $480 \mathrm{~nm}$ ). Los datos se expresan como la proporción entre la fluorescencia emitida por las muestras tratadas versus las muestras sin tratar.
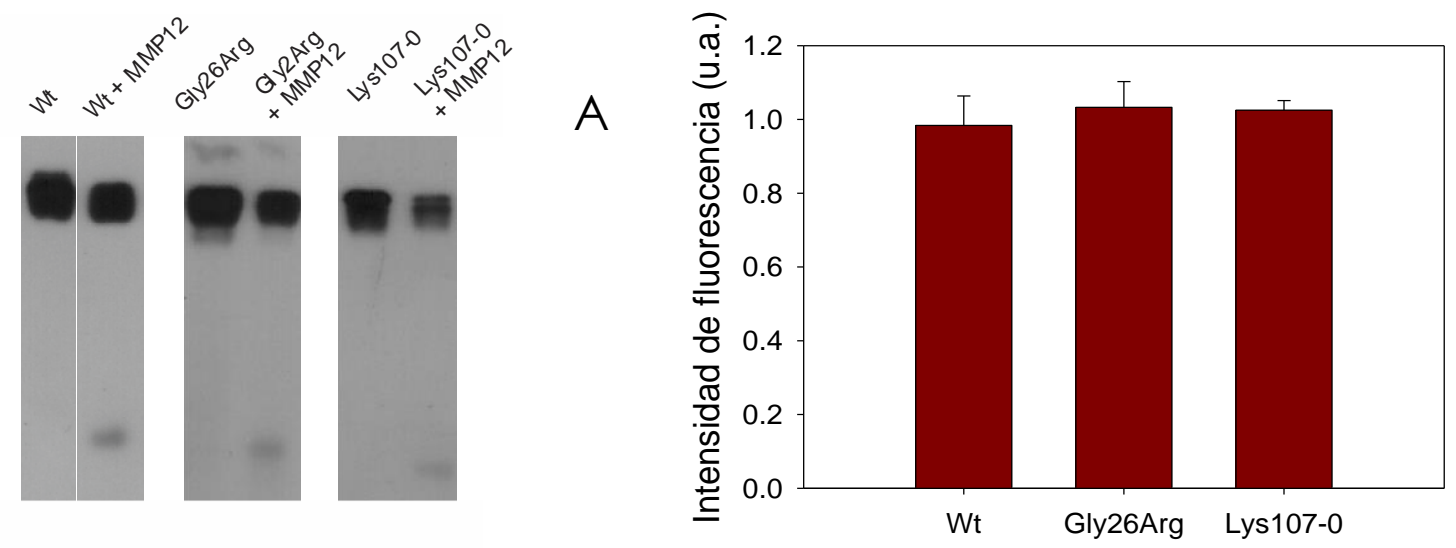

Figura. 6.4.2. Efecto de la actividad proteolítica de MMP-12 sobre las variantes de apoA-I. ApoA-I wt, Gly26Arg y Lys107-0 (7,2 $\mu \mathrm{M})$ fueron incubadas con MMP-12, a pH 7,4 y $37^{\circ} \mathrm{C}$ durante 1 h. A) Western blot realizado con anti-apoA-I. En todos los casos se sembró igual cantidad de proteína. B) Unión de ThT. Las muestras provenientes del ensayo fueron incubadas $24 \mathrm{~h}$ a $37^{\circ} \mathrm{C}$. Luego se agregó ThT a cada muestra en una concentración final de $10 \mu \mathrm{M}$ y se leyó fluorescencia en un lector de placas (filtro excitación: 430 nm, filtro emisión: $480 \mathrm{~nm}$ ). Los datos se expresan como la proporción entre la fluorescencia emitida por las muestras tratadas versus las muestras sin tratar. 


\subsection{Activación de macrófagos por las variantes amiloidogénicas de apoA-I.}

Para determinar si las variantes de apoA-I pueden por si mismas activar a los macrófagos y de este modo inducir una respuesta del tipo inflamatoria, ensayamos la producción de especies reactivas de oxigeno (ROS), TNF-a e IL-1 $\beta$ en la línea celular de macrófagos murinos RAW 264.7. Se utilizó polimixina B como secuestrante de LPS para eliminar los efectos de una posible contaminación con pequeñas cantidades de endotoxinas remanente luego de la purificación de las proteínas recombinantes. Cuando las células fueron incubadas con $50 \mu \mathrm{g} / \mathrm{ml}$ de polimixina B, la producción de ROS inducida por LPS fue completamente inhibida (Fig. 6.5.1 A), mientras que en ausencia polimixina B la producción de ROS fue significativa. Tanto apoA-I como la variante Lys 107-0 no indujeron la producción de ROS en los macrófagos, no obstante cuando las células se incubaron con 1 $\mu \mathrm{g} / \mathrm{ml}$ de la variante Gly26Arg se registró un aumento significativo en la producción de ROS (Fig. 6.5.1 A). De igual modo, cuando se ensayó la liberación de TNF-a e IL$1 \beta$, sólo la variante Gly 26 Arg indujo producción significativa de estas citoquinas en nuestras condiciones de medida (Fig. 6.5.1 B y C). Las mediciones en la reducción de MTT indicaron que la viabilidad celular se mantuvo en las distintas condiciones ensayadas (no mostrado). 
Figura. 6.5.1. Efecto de las variantes de apoA-I sobre la activación pro-inflamatoria de macrófagos. A células RAW 264.7 se les agregó apoA-I wt, Gly26Arg o Lys 107-0 en una concentración de $1 \mu \mathrm{g} / \mathrm{ml}$ junto con $50 \mu \mathrm{g} / \mathrm{ml}$ de polimixina B. Las barras llamadas "B" representan el control negativo el cual se realizó con medio sin proteínas. La polimixina se utilizó como agente secuestrante del LPS a modo de bloquear su efecto sobre las células (LPS + P). LPS, en $1 \mathrm{\mu g} / \mathrm{ml}$, en ausencia de polimixina (LPS - P) se usó como control positivo de la activación. A) La producción de ROS se determinó por fluorescencia de DCF luego de incubar las células durante 6 horas con los distintos tratamientos. B) y C) La producción TNF-a e IL- $\beta$ se cuantificó empleando kits comerciales como se describe en materiales y métodos. \# representa diferencias significativas respecto del control "B" $(p<0,05) . \quad *$ representa diferencias significativas respecto de las células incubadas con la proteína wt $(p<0,05)$.
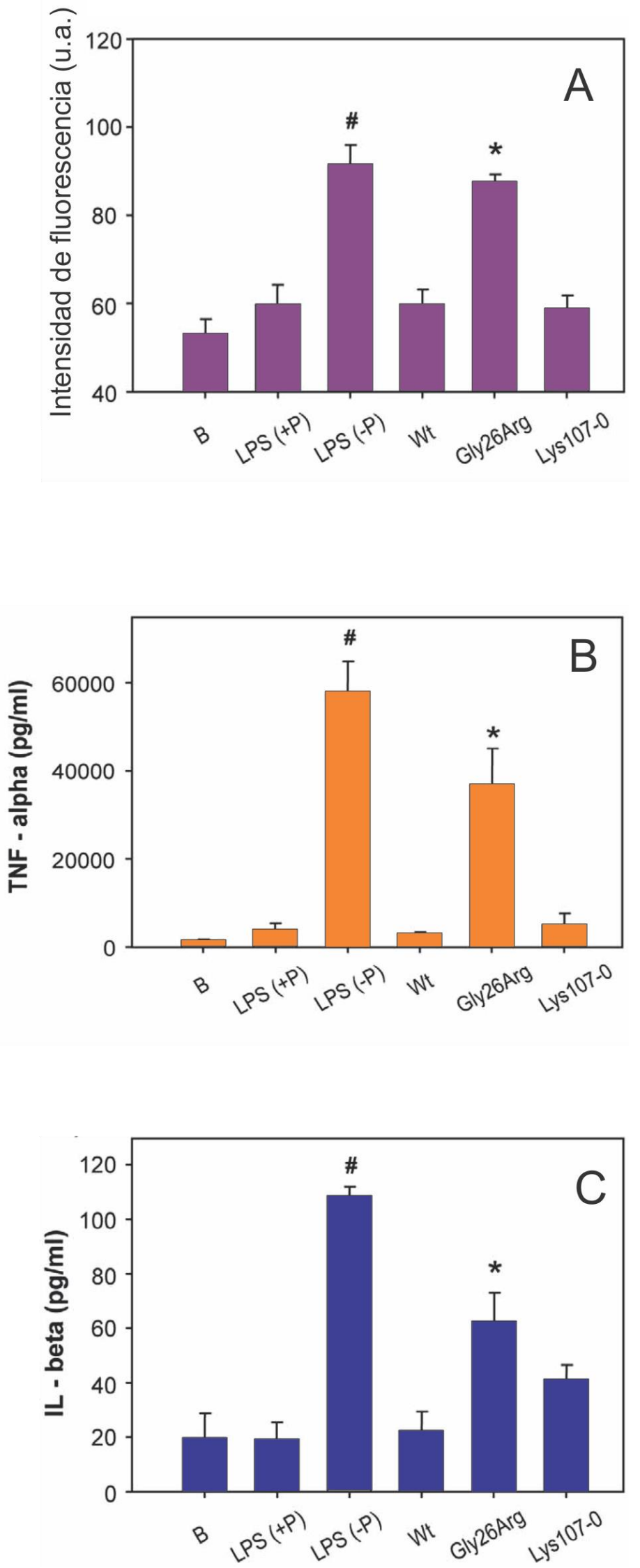


\section{Discusión.}

La eficiencia funcional de gran parte de las proteínas, incluyendo las apolipoproteínas intercambiables humanas como la apoA-l, se basa en gran parte en el potencial para interactuar con una gran variedad de ligandos en circulación, lo que requiere una adaptación estructural que reconozca cada entorno de manera específica. Esta flexibilidad estructural representa, por otro lado, un alto riesgo de estas proteínas de ser modificadas por dicho entorno, rindiendo conformaciones que se tornen citotóxicas por mecanismos que en general son difíciles de predecir. Así por ejemplo, una mutación puntual puede resultar en amiloidosis hereditaria, como fue descrito para numerosas variantes naturales de apoA-I. Con el objetivo de profundizar los conocimientos sobre las amiloidosis inducidas por esta proteína, y dilucidar además la existencia de uno o varios mecanismos que puedan ser reconocidos como causantes de tal patología, propusimos este trabajo, eligiendo dos variantes mutantes naturales que fueron identificadas en pacientes con amiloidosis, y exploramos su agregación bajo distintas condiciones.

Cabría esperar, ante un diseño experimental como el propuesto, que la proteína con la secuencia nativa sirva del control adecuado. Sin embargo, como era esperable en base a las referencias bibliográficas, la proteína wt mostró ante resultados preliminares una cierta susceptibilidad para agregarse. Así, nos propusimos iniciar previamente un análisis exhaustivo del efecto del microambiente celular sobre la apoA-l wt, para luego poder comparar con certeza el comportamiento de las variantes mutantes frente a la proteína con la secuencia nativa.

\subsection{Influencia del pH sobre la estabilidad y agregación de apoA-I wt.}

Si bien apoA-I wł por sí misma es muy poco propensa a agregarse, se la ha localizado depositada junto a lesiones ateroscleróticas como agregados de tipo amiloide (Mucchiano y col., 2001; Westermark y col., 1995). No obstante es muy 
poco lo que se conoce acerca de los mecanismos que predisponen a la proteína a formar estos agregados tan característicos. La aterosclerosis es un proceso patológico que no es posible separar del contexto de inflamación crónica, el cual, como se ha mencionado, se caracteriza por la presencia de células del sistema inmune activadas lo que genera un ambiente oxidativo y proteolítico (sus efectos se discuten en ítem 7.4) (Pober y Sessa, 2007). Pero también en respuesta al proceso inflamatorio las vías que conducen a la apoptosis se encuentran muy activas (Wright y col., 2010) y en consecuencia se produce en células apoptoticas la externalización de la fosfatidilserina produciendo una caída local del pH (Zhao y col., 2004). Por esta razón resulta de particular interés estudiar cómo responde en términos estructurales apoA-I wt bajo la influencia de distintos $\mathrm{pH}$.

Los ensayos de desnaturalización química (Fig. 5.1.1), apagado con acrilamida (Fig. 5.1.2) y unión de bis-ANS (Fig. 5.1.3), suponen una estructura flexible de glóbulo fundido a pH fisiológico que está altamente preservada a pH 5,0 y se pierde drásticamente a pH 4,0. Sin embargo se observa que tanto a pH 4,0 como a pH 5,0 (aunque algo menos en el último caso) hay unión de ThT y sedimentación de material, lo que sugiere la formación de estructuras amiloides que se agregan fácilmente cuando son centrifugadas a baja velocidad (Fig. 5.2.1). En cambio para los valores de pH 6,0 y 7,4 la unión de ThT es mínima (comparable con el blanco sin proteína) y no hay sedimentación significativa de material. Es de relevante importancia notar que el pl de la proteína recombinante es de 5,46. En base a los datos obtenidos uno podría suponer que a pHs por debajo del pl la apoA-I experimenta modificaciones que comprometen su estructura y su estabilidad, si bien las modificaciones mencionadas son mínimas a pH 5,0. No obstante por debajo de su pl la protonación de alguno de sus residuos puede alterar las interacciones fisiológicas de la proteína, ya sea con otros ligandos o intermoleculares, lo cual puede conducir a formación de estructuras oligoméricas fácilmente sedimentables. En soporte a estos resultados, en las imágenes de microscopía, tanto de AFM como de TEM, se aprecia el depósito de abundantes agregados cuando éstas son tratadas a pH 5,0 mientras que a pH 7,4 la formación de oligómeros sobre el soporte es mínima (Fig. 5.2.2). Como fue descrito en 
resultados, el agregado que predomina en estas condiciones son oligómeros, aunque al aumentar la concentración puede detectarse además la presencia en algún campo de protofibrillas.

\subsection{ApoA-I wł y unión a heparina.}

Es sabido que los GAGs, principalmente el más abundante de ellos que es la heparina, actúan sobre varias proteínas induciendo su agregación y la formación de fibras amiloides favoreciendo el proceso de nucleación (Suk y col., 2006). Los motivos de unión a heparina reportados son del tipo XBBXBX y XBBBXXBX, donde $B$ representa un aminoácido básico (Lis, Arg, His) y $X$ cualquier otro aminoácido. El modelo sugiere que si el primer motivo se encuentra formando parte de una estructura tipo hoja- $\beta$ los aminoácidos básicos quedarían alineados todos en la misma cara de la estructura, lo mismo ocurriría con el segundo motivo pero cuando éste se encuentra presente en una a-hélice (Cardin y Weintraub, 1989). Por otro lado, Margalit y col. proponen que una distancia de $20 \AA$ entre los residuos básicos es importante para la interacción con heparina (Margalit y col., 1993). Si bien la apoA-I wł no presenta motivos típicos de unión a heparina y publicaciones previas indican la ausencia de esta unión en condiciones fisiológicas (Harel y col., 1990), según los resultados obtenidos se aprecia una interacción de carácter electrostático entre la heparina y la proteína cuando el medio tiene un pH por debajo del pl para apoA-I (o de pH 6,0), mientras a pH 6,0 ० 7,4 no hay diferencias significativas con los controles sin heparina. El grupo imidazol $(\mathrm{pl} \sim 6,0)$ de la His es el único residuo que ioniza dentro de las variaciones esperadas para el rango fisiológico y apoA-I tiene cinco residuos de His (en posiciones 135, 155, 162, 193 y 199); si se observa la secuencia de aminoácidos con un simulador de a-hélices? (Figura 7.2.1.) se aprecia que las His en posición 155 y 162 quedan apiladas una encima de la otra en un giro de la hélice. De este modo cuando la proteína se encuentra por debajo de $\mathrm{pH}$ 6,0 los residuos adquieren carga positiva y puesto el carácter altamente negativo de los GAGs resulta en un posible sitio de unión a

\footnotetext{
1 http://cti.itc.virginia.edu/ cmg/Demo/wheel/wheelApp.html
} 
heparina que depende del pH. Más aún un residuo de Arg queda justo por encima de las dos His mencionadas lo que aumenta la carga positiva en esa zona y contribuiría con tal interacción. Aunque las demás His no queden dispuestas como las recién mencionadas, no se puede descartar que también estén participando en la interacción con la heparina cuando el pH es por debajo de 6,0. En la figura también se observa, opuesto al sitio mencionado, tres Arg dispuestas una encima de otra, por su pl las Arg mantiene la carga positiva a todos los pH ensayados. Sin embargo no estarían disponibles para interaccionar con la heparina puesto no hay resultados significativos a pH 6,0 y 7,4.

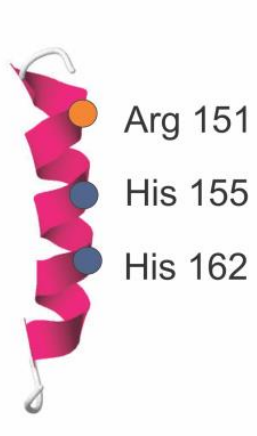

A

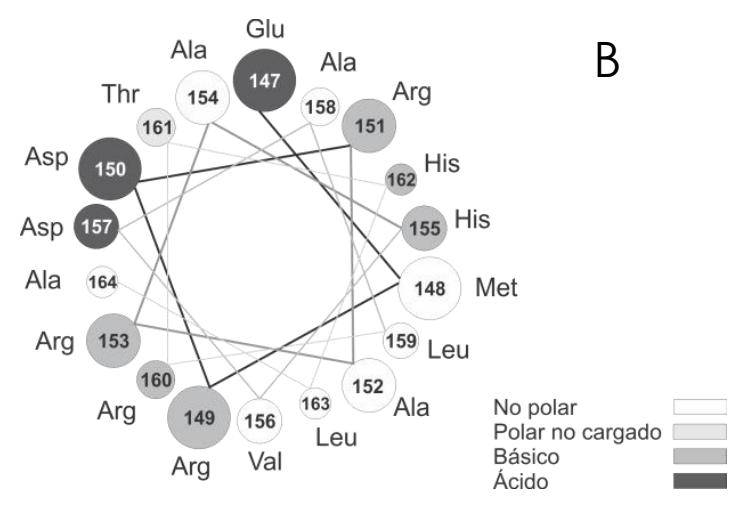

Figura 7.2.1. Distribución de las His 155 y 162 en un modelo a-hélice. A) Vista lateral y B) vista superior del péptido de apoA-l involucrando la hélice 143-164 según modelado de a-hélice.

\subsection{Estabilidad y agregación de las variantes apoA-I Gly26Arg y apoA-I Lys107-0.}

A fin de indagar y detectar posibles diferencias estructurales que justifiquen la patogenicidad de los mutantes Gly26Arg y Lys 107-0, distintos ensayos se realizaron a pH 7,4 y a bajas concentraciones de proteína comparando su comportamiento con la secuencia wt. Ambas mutantes mostraron diferencias conformacionales respecto de la proteína wt: son menos estables (Fig. 6.2.1) y presentan mayor intensidad de fluorescencia intrínseca del Trp (Fig. 6.1.1). En estudios previos fue demostrado que al menos dos de los residuos Trp de la apoA-I experimentan homotransferencia de energía fluorescente, lo que lleva a una 
disminución del rendimiento cuántico de los residuos donores (Davidson y col., 1999). Dado que la transferencia de energía es un proceso dependiente de la distancia, el aumento de fluorescencia intrínseca observada en los mutantes podría indicar una estructura más relajada, con los residuos en promedio más alejados entre sí. Otro hallazgo interesante es la presencia en los mutantes de un arreglo espacial que une más bis-ANS. Estos datos sugieren una estructura más flexible con mayor penetrancia de agua, lo que debilita las interacciones hidrofóbicas y por ende estos dominios hidrofóbicos quedan más expuestos. Se puede decir que las dos mutantes presentan un estado de glóbulo fundido más flexible que el que presenta la proteína wt.

Además de unir más bis-ANS, las dos mutantes presentan un leve corrimiento de los espectros de bis-ANS hacia el azul respecto de la proteína wt (Fig. 6.1.3 inserto), si bien esto indicaría un entorno ligeramente más hidrofóbico, dada la sensibilidad de la sonda (Hawe y col., 2008) este cambio no puede considerarse significativo.

La comparación del perfil de desnaturalización seguido por fluorescencia intrínseca y por fluorescencia de bis-ANS (Fig. 6.2.3) nos dice que la conformación de glóbulo fundido y bolsillos hidrofóbicos (censados por bis-ANS) se pierden a menores concentraciones de $\mathrm{GndHCl}$ que las requeridas para la pérdida de las estructuras secundaria que mantienen a los Trp compactados y próximos. Esta observación se hace evidente del solapamiento de ambas curvas de desnaturalización (Fig. 6.2.3). Estos datos indican la existencia de diferentes intermediarios durante el desplegamiento de la apoA-I. Es importante tener presente que la existencia de estados intermedios, revelados por bis-ANS, pueden adquirir una conformación mal plegada relativamente estable la cual es propensa de agregación. Estos estados intermedios son los responsables de la agregación en otras proteínas amiloidogénicas (Martins y col., 2003; Canet y col., 1999).

La caracterización de los agregados por AFM nos muestra la formación de oligómeros de distinta forma y dimensión dependiendo la proteína, pero en ninguno de los caso se observaron fibras en las condiciones ensayadas ( $24 \mathrm{~h}$ a 37 ${ }^{\circ} \mathrm{C}$ y una concentración final de 21,6 $\mu \mathrm{M}$ ). Existen varias estrategias para acortar 
los tiempos de formación de fibras (temperaturas, presión, agitación, tiempos de incubación etc.) que se alejan dramáticamente de las condiciones fisiológicas. Con excepción de los ensayos de microscopía, donde la concentración de proteína usada fue mayor que la usada en otros ensayos, nuestro objetivo no fue forzar la formación de fibras, sino más bien permanecer próximo a las condiciones fisiológicas (baja concentración, $37{ }^{\circ} \mathrm{C}$ y tiempos cortos de incubación). Es interesante observar que, a pesar de la diferencia estructural y la disminución de estabilidad detectadas para ambos mutantes, sólo Lys 107-0 parece tener mayor tendencia a agregarse dadas las observaciones de AFM, lo cual indicaría que estos motivos no son suficientes para determinar la agregación al menos como mecanismo general de patología.

\subsection{Efectos del microambiente inflamatorio sobre la integridad y agregación de apoA-I wt, Gly26Arg y Lys 107-0.}

Los resultados obtenidos cuando la apoA-I wt fue expuesta a las inclemencias de un ambiente pro-inflamatorio sugieren que estas condiciones favorecen notablemente el procesamiento pro-amiloidogénico de la proteína (Fig. 5.4.1 y 5.4.3). Cuando se ensayó apoA-I wł en presencia de MMP-12 (una enzima presente en lesiones inflamatorias crónicas) no se observó aumento en la unión de ThT a pesar de que hubo proteólisis, e inclusive se puede observar la aparición de un péptido de aproximadamente $11 \mathrm{kDa}$ (Fig. 5.4.2) el cual coincide con la bibliografía revisada como uno de productos típicos de apoA-I presentes en placas ateromatosas y lesiones amiloides. Es llamativo que este péptido tan frecuente en las lesiones no resulte con mayor fluorescencia de ThT en el ensayo, como sí ocurre con las muestras incubadas con PMN ó HClO. En base a los resultados obtenidos podemos pensar que como resultado de la oxidación, ya sea por $\mathrm{HClO}$ o por los ROS liberados por los $\mathrm{PMN}$, se generan productos fácilmente entrecruzables que dan como resultado la agregación y formación de fibras amiloides, como se observa en el western blot luego de incubar con $\mathrm{HClO}$ (Fig. 5.4.3) y en la caracterización de los productos de oxidación por AFM (Fig. 5.4.4). En 
adición se ha demostrado que la oxidación de Met mediada por $\mathrm{H}_{2} \mathrm{O}_{2}$ promueve la agregación de apoA-I wł (Wong y col., 2010).

Conjuntamente con los resultados descriptos arriba, podríamos sugerir que el descenso de $\mathrm{pH}$ favorece la formación de agregados de apoA-l, pero en particular favorece la unión y por tanto la retención de la proteína en unión a GAGs. Si este entorno está dado por la presencia de un microentorno inflamatorio, tanto PMN como macrófagos pueden inducir un procesamiento irreversible de la apoA-l, incluyendo oxidación y proteólisis con rendimiento de productos amiloidogénicos.

Es de esperar además que ante el daño oxidativo la función biológica de la proteína se vea fuertemente afectada como se aprecia en el ensayo de remoción de colesterol (Fig. 5.4.5). Este resultado coincide con el trabajo de Zheng y colaboradores donde la acción de la mieloperoxidasa sobre apoA-I wł resulta en la nitración y clorinación de Tyr y en consecuencia hay pérdida en la capacidad de activar al ABCAl y por ende en la remoción de colesterol contribuyendo a la generación de placas ateromatosas (Zheng y col., 2004). Si este es el caso, nuestros resultados apoyan un complejo panorama, en donde ambas patologías crónicas, aterosclerosis y amiloidosis se retroalimentan, involucrando al menos un procesamiento patológico de la apoA-I en donde la relación estructura-funciónpatogenicidad se ven altamente relacionadas.

La próxima pregunta a contestar fue: ¿̇podrá deberse el mecanismo patológico de las variantes mutantes a una aumentada susceptibilidad para ser degradadas por el ambiente pro-inflamatorio dando complejos citotóxicos? Esta pregunta se sustenta además en la hipótesis de que, al ser característica en las amiloidosis hereditarias la presencia de un péptido $\mathrm{N}$-terminal en las lesiones, podría suponerse que la mutación induce ya sea una mayor exposición de una zona de clivaje, o la aparición de un nuevo sitio de corte con enzimas proteolíticas. Con tal fin, comparamos el efecto del ambiente pro-inflamatorio sobre las mutantes estudiadas. De manera interesante, la degradación mediada por MMP12 resultó sin incremento en la unión de ThT pero con la aparición de un péptido de aproximadamente $11 \mathrm{kDa}$ (Fig. 6.4.2), aproximadamente con el mismo 
rendimiento para las variantes con respecto al wt. A fin de intentar aumentar la eficiencia del proceso se ensayaron mayores tiempos de incubación y de relaciones molares enzima:apo, pero esos casos resultaron en la proteólisis exhaustiva, sin encontrar en ningún caso formación de productos intermedios con mayor unión de Tht (no mostrado). Si bien es muy probable que este tipo de proteólisis ocurra in vivo, quizá la proteasa específica que tenga mayor afinidad por la apoA-I sea otra de las varias presentes en las lesiones. En el ensayo con PMN ambas mutantes parecieran ser más susceptibles a la degradación mediada por PMN, en base a la intensidad de la banda remanente como monómero en el western blot luego de la incubación (esta cuantificación no fue confirmada dada la gran variabilidad de la técnica); no obstante el producto resultante de la apoA-I Lys 107-0 une considerablemente más ThT que la apoA-I wł y la variante Gly26Arg (entre las cuales no hay diferencia) (Fig. 6.4.1). La razón de este hallazgo no es clara al momento (y será investigada a futuro) dada la compleja batería de reacciones puestas en juego en el estrés oxidativo activado en estas células. Sin embargo es oportuno recordar que la variante Lys 107-0 se asocia con el desarrollo de aterosclerosis severa (Mucchiano y col., 2001). Según esto datos y la patología asociada a la mutante, podría inferirse que la deleción de la Lys en posición 107 produce una conformación que resulta más sensible al procesamiento mediado por PMN y la formación de estructuras amiloides. Sumada a la tendencia a la agregación de los mutantes, demostramos en este trabajo la pérdida de función inespecífica que estas proteínas pueden experimentar asociada al microambiente. Pero además debiera considerarse la influencia de cada mutación en la participación de los distintos mecanismos de señalización en los que participen asociados a su función en el TRC. Gonzalez y colaboradores han demostrado que la apo Lys107-0 pierde su habilidad para inducir movilización de colesterol intracelular desde cultivos de células $\mathrm{CHO}$, y de esterificar colesterol desde pooles intracelulares (Gonzalez y col., 2008). La deleción del residuo 107 cambia cerca de $100^{\circ}$ la orientación de las caras hidrofílica e hidrofóbica de la hélice 4 de la apo a ambos lados de la mutación. Así es probable que la pérdida de este residuo desorganice la conformación proteica, de manera de afectar su 
interacción con lípidos o con otras proteínas involucradas en la señalización de la remoción de colesterol. Como la amiloidosis derivada de Lys107-0 es asociada a severa aterosclerosis (Mucchiano y col., 2001), es probable una probable relación cercana entre ambas patologías.

\subsection{Activación de macrófagos por las variantes de apoA-I.}

Si bien los resultados de las condiciones inflamatorias sobre el procesamiento de las proteínas fueron claros en cuanto al procesamiento pro-amiloidogenico, cabía estudiar la posibilidad del camino inverso, es decir, de si las variantes amiloidogénicas de apoA-I por si sola eran capaces de inducir una respuesta del tipo inflamatoria mediante la activación de células del sistema inmune como ya había sido descripto para a-sinucleína (Wei Zhang y col., 2005) y para SAA (Lee y col., 2006). Para esto se realizaron ensayos incubando las variantes de apoA-I con macrófagos murinos (Fig. 6.5.1). Resulta altamente interesante que en las condiciones ensayadas solo apoA-I Gly26Arg, y no las otras dos variantes, es capaz de inducir a las células a producir ROS, TNF-a e IL-1. De este modo queda expuesta la posibilidad de que el cambio conformacional que introduce la sustitución del aminoácido en posición 26 por una Arg pueda iniciar y perpetuar una respuesta inflamatoria asociada con la disfunción del órgano afectado.

En conclusión, en este trabajo he analizado y comparado características estructurales que puedan favorecer la agregación patológica de dos variantes naturales puntuales de la apoA-l humana. Algunos parámetros parecen ser compartidos por ambas variantes, tales como la presencia de una estructura más flexible e inestable que la proteína wt. De cualquier modo, este hecho no parece suficiente para explicar la aumentada patogenicidad que muestran, ya que la variante Gly26Arg muestra una tendencia similar al wt para agregarse en forma de compuestos amiloides. Así además del procesamiento que el microambiente pueda hacer sobre la proteína, puede ser considerado que en cambio el ligero cambio conformacional que pueda inducir la mutación, pueda desencadenar procesos de señalización específicos que expliquen un comportamiento anómalo, y así la activación de macrófagos podría ser una hipótesis atractiva para explicar 
el porqué de la patogenicidad de alguna variante. Por último, la identificación de procesos específicos que modelen la patogenicidad de las distintas variantes abre un vasto campo de investigación para conocer y entender las amiloidosis hereditarias debidas a apoA-I. 


\section{Conclusiones}

I. En condiciones fisiológicas la apoA-l wt presenta una estructura concordante con un estado de glóbulo fundido. El descenso de $\mathrm{pH}$ favorece su agregación. A pH 5,0 la estructura está altamente preservada pero sin embargo se detecta un aumento de agregación. Bajo estas condiciones predominan complejos amiloides de tipo oligómeros. Con el descenso de pH aumenta además la unión a heparina, formando complejos mediante interacción electrostática.

II. Ambos mutantes, Gly26Arg y Lys107-0, son estructuralmente más inestables que la apoA-I wł a pH 7,4. Poseen además una estructura concordante con el estado de glóbulo fundido pero más relajada, con residuos Trp más separados entre sí y mayor número de bolsillos hidrofóbicos. Lys 107-0 forma agregados significativamente más altos y heterogéneos que wł y Gly26Arg.

III. MMP-12 cataliza la proteólisis de las tres variantes de apoA-I y genera un péptido de aproximadamente 11 kDa. Este péptido sin embargo no parece ser amiloidogénico. El HClO favorece la formación de productos de entrecruzamiento. Los productos resultantes unen más ThT. Las reacciones asociadas a PMN previamente activados (proteólisis, oxidación) afectan la integridad de las tres variantes de apoA-I. Los productos unen significativamente más ThT y se observa presencia de fibras cortas además de los oligómeros. Lys107-0 muestra mayor sensibilidad a estas modificaciones. Estos resultados definen un rol protagónico de la oxidación como mecanismo general de procesamiento pro-amiloidogénico de apoA-I.

IV. Solo ApoA-I Gly26Arg (y no wt o Lys107-0) es capaz de inducir señales proinflamatorias (ROS, ILI-B y TNF-a) desde macrófagos murinos (RAW 264.7). Este hecho plantea la posibilidad de que distintas y específicas vías de señalización puedan mediar la patogenicidad de las distintas variantes. 


\section{Modelo y perspectivas.}

En base a lo tratado en la introducción y a los resultados y conclusiones obtenidos, se plantea un modelo (Fig. 9) donde las tres variantes de apoA-I se ven afectadas por el entorno inflamatorio lo cual conduce a su procesamiento proamiloidogénico y donde también las GAGs contribuyen con el proceso de nucleación y agregación. Los productos de agregación son causantes de daño tisular y, dependiendo la variante, desarrollo de ateroma lo que genera señales del tipo inflamatorias produciéndose una retroalimentación positiva del sistema. Solo la variante apoA-I Gly26Arg es capaz por si sola de activar macrófagos y desencadenar todo el proceso inflamatorio.

En el modelo propuesto se omite la presencia de dos actores muy importantes como lo son las lipoproteínas de transporte, principalmente las HDL donde la apoA-l juega un rol preponderante, y las células endoteliales que también son capaces de generar señales inflamatorias y reclutar células del sistema inmune. Lo omisión se debe a que no se han realizado ensayos con ninguno de estos dos elementos. Sin embargo no es posible tener una visión completa del sistema sin considerar la participación de ambos.

Si bien los resultados obtenidos echan luz sobre los objetivos planteados, de ellos decantan varios interrogantes que requieren más y diversos experimentos. Como perspectivas a futuro resulta por demás interesante:

1) entender el rol de las células endoteliales en el modelo planteado: źresultan las variantes amiloidogénicas de apoA-I citotóxicas para el endotelio y en todo caso son capaces de inducir el fenotipo pro-inflamatorio?

2) Los ensayos realizados con macrófagos murinos son una buena aproximación al modelo humano, no obstante se propone realizar experimentos con monocito humanos y estudiar si los productos amiloides de apoA-I son capaces de promover su diferenciación a macrófagos.

3) Reconociendo la limitación de algunas técnicas utilizadas para la caracterización estructural de las variantes proteicas, es requerido un estudio exhaustivo de las mismas, a fin de poder obtener mayor información estructural de las mismas. Estudios preliminares de fluorescencia con sondas 
ESIPT (excited-state intramolecular proton transfer) y de Fluorescence Correlation Spectroscopy (FCS), indican que estas mediciones son altamente apropiadas para profundizar estos estudios. Asimismo nuestro uso de AFM en el presente trabajo es introductorio considerando la potencialidad de la técnica, y creemos necesario profundizarlos variando las condiciones de agregación de la proteína.

4) Finalmente la detección de factores específicos determinando la patogenicidad de cada mutante abre un campo más que vasto para dilucidar la patogénesis asociada a las variantes de apoA-I. Causas locales que favorezcan su agregación (glicosilación, efectos de concentración de urea, crowding, etc.) son potenciales campos de investigación, en particular para mutantes asociados con insuficiencia renal. Pero en especial la inducción de señales celulares será motivo prioritario de estudio en el futuro inmediato. 


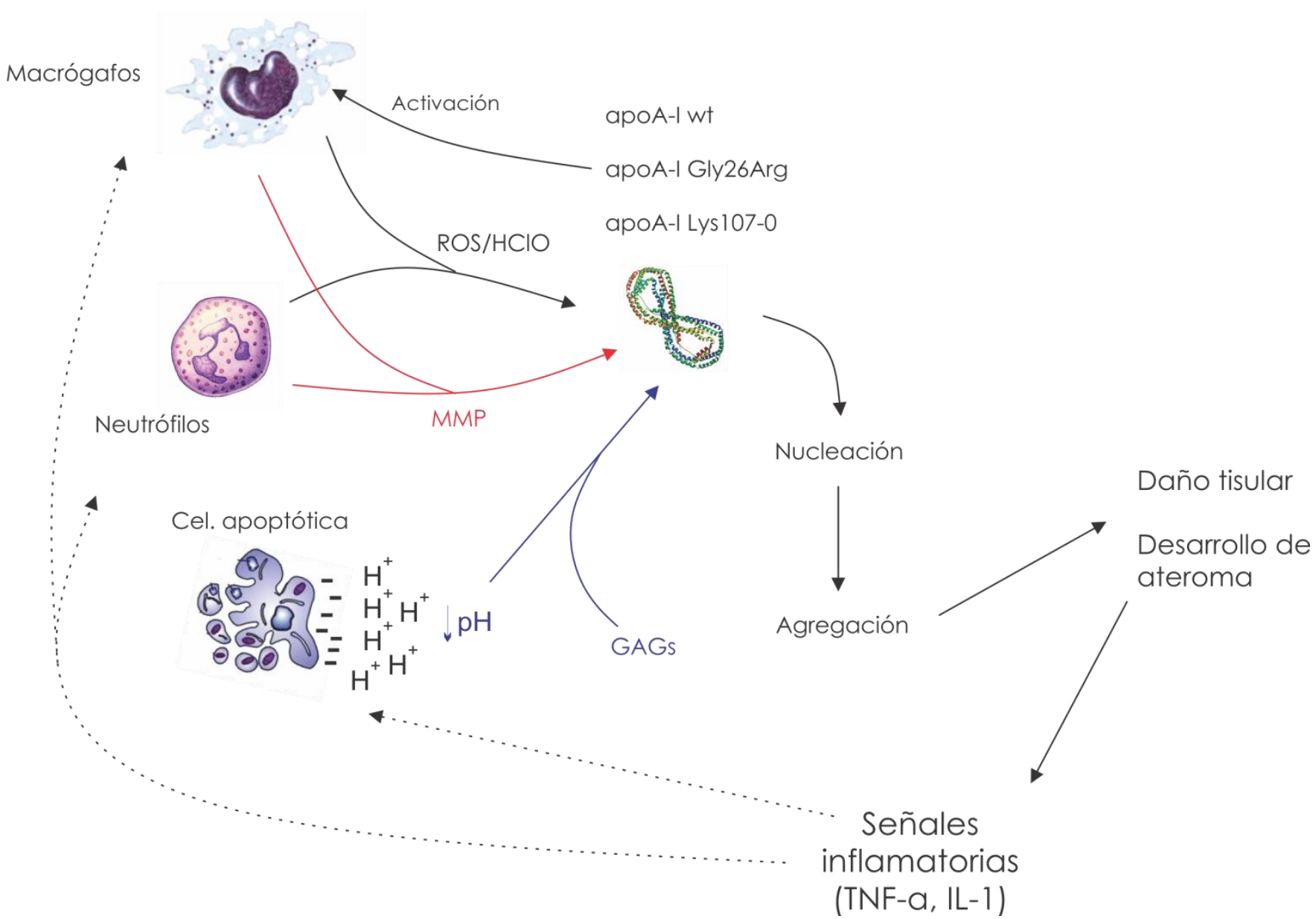

Figura 9. Modelo que vincula la agregación de apoA-I con el entorno inflamatorio. Las células apoptóticas externalizan la fosfatidilserina (fosfolípido con carga negativa) lo que genera una caída local del pH afectando la estabilidad de las variantes de apoA-l y promoviendo la agregación de estas. La heparina (GAGs), bajo la influencia del pH ácido, facilita la nucleación de apoA-I y la agregación. EL estallido oxidativo y ataque proteolítico generado por neutrófilos y macrófagos, cuando estos reciben un estímulo antigénico (agentes locales o las mismas variantes proteicas), también provocan la agregación de las proteínas. Los productos de agregación generan daño tisular y en algunos casos el desarrollo de lesiones ateroscleróticas, las células endoteliales responderían generando señales pro-inflamatorias que resultan en el reclutamiento y activación de células del sistema inmune. De esta forma se genera un sistema que es continuamente retroalimentado. Solo la variante apoA-I Gly26Arg es capaz de inducir a los macrófagos a establecer una repuesta inflamatoria. 


\section{Bibliografía.}

Adachi, E., Nakajima, H., Mizuguchi, C., et al. (2012) Dual Role of an N-terminal Amyloidogenic Mutation in Apolipoprotein A-I: Destabilization of Helix Bundle and Enhancement of Fibril Formation. The Journal of biological chemistry, 1-20.

Ansell, B.J., Watson, K.E., Fogelman, A.M., Navab, M. and Fonarow, G.C. (2005) High-density lipoprotein function recent advances. Journal of the American College of Cardiology, 46, 17928.

Baynes, J. y Dominiczak, M. (2011) Bioquímica médica. 3 edición. Elsevier.

Borhani, D.W., Rogers, D.P., Engler, J. a and Brouillette, C.G. (1997) Crystal structure of truncated human apolipoprotein A-I suggests a lipid-bound conformation. Proceedings of the National Academy of Sciences of the United States of America, 94, 12291-6.

Canet, D, Sunde, M, Last, a M., Miranker, a, Spencer, a, Robinson, C V and Dobson, C M (1999) Mechanistic studies of the folding of human lysozyme and the origin of amyloidogenic behavior in its disease-related variants. Biochemistry, 38, 6419-27.

Canet, Denis, Sunde, Margaret, Last, A.M., Miranker, A., Spencer, A., Robinson, Carol V and Dobson, Christopher M (1999) Mechanistic Studies of the Folding of Human Lysozyme and the Origin of Amyloidogenic Behavior in Its Disease-Related Variantst. Biochemistry, 38, 6419-6427.

Cardin, A.D. and Weintraub, H.J. (1989) Molecular modeling of protein-glycosaminoglycan interactions. Arteriosclerosis, Thrombosis, and Vascular Biology , 9, 21-32.

Cohlberg, J. a, Li, J., Uversky, V.N. and Fink, A.L. (2002) Heparin and other glycosaminoglycans stimulate the formation of amyloid fibrils from alpha-synuclein in vitro. Biochemistry, 41, 1502-11.

Curtiss, L.K., Valenta, D.T., Hime, N.J. and Rye, K.-A. (2006) What is So Special About Apolipoprotein Al in Reverse Cholesterol Transport? Arteriosclerosis, Thrombosis, and Vascular Biology , 26 , 12 19.

Davidson, W.S., Arnvig-McGuire, K., Kennedy, A., Kosman, J., Hazlett, T.L. and Jonas, Ana (1999) Structural Organization of the N-Terminal Domain of Apolipoprotein A-I: Studies of Tryptophan Mutantst. Biochemistry, 38, 14387-14395.

Davidson, W.S. and Thompson, T.B. (2007) The structure of apolipoprotein A-I in high density lipoproteins. The Journal of biological chemistry, 282, 22249-53.

Eriksson, M., Schönland, S., Yumlu, S., et al. (2009) Hereditary apolipoprotein Al-associated amyloidosis in surgical pathology specimens: identification of three novel mutations in the APOAl gene. The Journal of molecular diagnostics : JMD, 11, 257-62.

Ferreira, Sergio T, Vieira, M.N.N. and Felice, F.G. De (2007) Soluble protein oligomers as emerging toxins in Alzheimer's and other amyloid diseases. IUBMB life, 59, 332-45.

Fogelman, A.M. (2004) When good cholesterol goes bad. Nature medicine, 10, 902-3. 
Gonzalez, M.C., Toledo, J.D., Tricerri, M.A. and Garda, H.A. (2008) The central type Y amphipathic ahelices of apolipoprotein Al are involved in the mobilization of intracellular cholesterol depots. Archives of Biochemistry and Biophysics, 473, 34-41.

Gursky, O. and Atkinson, D (1996) Thermal unfolding of human high-density apolipoprotein A-1: implications for a lipid-free molten globular state. Proceedings of the National Academy of Sciences of the United States of America, 93, 2991-5.

Hardy, J. (2002) The Amyloid Hypothesis of Alzheimer's Disease: Progress and Problems on the Road to Therapeutics. Science, 297, 353-356.

Harel, A., Fainaru, M., Rubinstein, M., Tal, N. and Schwartz, M. (1990) Fish apolipoprotein-A-I has heparin binding activity: implication for nerve regeneration. J Neurochem, 55, 1237-1243.

Hawe, A., Sutter, M. and Jiskoot, W. (2008) Extrinsic fluorescent dyes as tools for protein characterization. Pharmaceutical research, 25, 1487-99.

Invernizzi, G., Papaleo, E., Sabate, R. and Ventura, S. (2012) Protein aggregation: mechanisms and functional consequences. The international journal of biochemistry \& cell biology, 44, 1541-54.

Jaureguiberry, M., Tricerri, M.A., Sanchez, SusanaA., Garda, H., Finarelli, G., Gonzalez, M. and Rimoldi, O. (2010) Membrane Organization and Regulation of Cellular Cholesterol Homeostasis. Journal of Membrane Biology, 234, 183-194 LA - English.

Kisilevsky, R.R. (2000) Amyloids: tombstones or triggers? Nat Med, 6, 633-634.

Lakowicz, J.R. (2006) Principles of fluorescence spectroscopy, New York.

Lagerstedt, J.O., Cavigiolio, G., Roberts, L.M., Hong, H.-S., Jin, L.-W., Fitzgerald, P.G., Oda, M.N. and Voss, J.C. (2007) Mapping the structural transition in an amyloidogenic apolipoprotein A-I. Biochemistry, 46, 9693-9.

Lambert, M.P., Barlow, a K., Chromy, B. a, et al. (1998) Diffusible, nonfibrillar ligands derived from Abetal-42 are potent central nervous system neurotoxins. Proceedings of the National Academy of Sciences of the United States of America, 95, 6448-53.

Lee, H.Y., Kim, M., Park, K.S., et al. (2006) Serum Amyloid A Induces Contrary Immune Responses via Formyl Peptide Receptor-Like 1 in Human Monocytes. , 70, 241-248.

Leroy, A. and Jonas, A (1994) Native-like structure and self-association behavior of apolipoprotein A-I in a water/n-propanol solution. ACTA-BIOENERG, 1212, 285-294.

Levine, H. (1993) Thioflavine T interaction with synthetic Alzheimer's disease @ -amyloid peptides : Detection of amyloid aggregation in solution. , 404-410.

Margalit, H., Fischer, N. and Ben-Sasson, S. a (1993) Comparative analysis of structurally defined heparin binding sequences reveals a distinct spatial distribution of basic residues. The Journal of biological chemistry, 268, 19228-31.

Martins, S.M., Chapeaurouge, A. and Ferreira, Sérgio T (2003) Folding Intermediates of the Prion Protein Stabilized by Hydrostatic Pressure and Low Temperature. Journal of Biological Chemistry , 278, 50449-50455. 
Martins, S.M., Frosoni, D.J., Martinez, A.M.B., Felice, F.G. De and Ferreira, Sérgio T (2006) Formation of Soluble Oligomers and Amyloid Fibrils with Physical Properties of the Scrapie Isoform of the Prion Protein from the C-terminal Domain of Recombinant Murine Prion Protein mPrP-(121-231). Journal of Biological Chemistry , 281 , 26121-26128.

Matsunaga, A., Uehara, Y., Zhang, B. and Saku, K. (2010) Apolipoprotein A-I Mutations First Edit., Elsevier Inc.

Mei, X. and Atkinson, David (2011) Crystal structure of C-terminal truncated apolipoprotein A-I reveals the assembly of high density lipoprotein (HDL) by dimerization. The Journal of biological chemistry, 286, 38570-82.

Merlini, G. and Bellotti, V. (2003) Molecular mechanisms of amyloidosis. The New England journal of medicine, 349, 583-96.

Mucchiano, G.I., Jonasson, L., Häggqvist, B., Einarsson, E. and Westermark, P. (2001) Apolipoprotein A-I-derived amyloid in atherosclerosis. Its association with plasma levels of apolipoprotein A-I and cholesterol. American journal of clinical pathology, 115, 298-303.

Munishkina, L.A., Ahmad, A., Fink, A.L. and Uversky, V.N. (2008) Guiding Protein Aggregation with Macromolecular Crowding†. Biochemistry, 47, 8993-9006.

Munishkina, L.A. and Fink, A.L. (2007) Fluorescence as a method to reveal structures and membraneinteractions of amyloidogenic proteins. Biochimica et Biophysica Acta (BBA) - Biomembranes, 1768, 1862-1885.

Obici, L., Franceschini, G., Calabresi, L., Giorgetti, S., Stoppini, M., Merlini, G. and Bellotti, V. (2006) Structure, function and amyloidogenic propensity of apolipoprotein A-I. Amyloid: the international journal of experimental and clinical investigation : the official journal of the International Society of Amyloidosis, 13, 191-205.

Ohashi, R., Mu, H., Wang, X., Yao, Q. and Chen, C. (2005) Reverse cholesterol transport and cholesterol efflux in atherosclerosis. QJM: monthly journal of the Association of Physicians, 98 , 845-56.

Onat, D., Brillon, D., AM, S. and PC, C. (2011) Human vascular endothelial cells: a model system for studying vascular inflammation in diabetes and atherosclerosis. Curr Diab Rep, 11, 193-202.

Onuchic, J.N., Luthey-Schulten, Z. and Wolynes, P.G. (1997) Theory of protein folding: the energy landscape perspective. Annual review of physical chemistry, 48, 545-600.

O'Brien, R.J. and Wong, P.C. (2011) Amyloid precursor protein processing and Alzheimer's disease. Annual review of neuroscience, 34, 185-204.

O'Connell B.J. and Genest, J. (2001) High-density lipoproteins and endothelial function. Circulation, 104, 1978-1983.

Pace, C.N. (1986) [14]Determination and analysis of urea and guanidine hydrochloride denaturation curves. In S. N. T. B. T.-M. in E. C. H. W. Hirs, ed. Enzyme Structure Part L. Academic Press, pp. 266280.

Planté-Bordeneuve, V. and Said, G. (2011) Familial amyloid polyneuropathy. Lancet neurology, 10, 1086-97. 
Pober, J.S. and Sessa, W.C. (2007) Evolving functions of endothelial cells in inflammation. Nature reviews. Immunology, 7, 803-15.

Quintas, a, Vaz, D.C., Cardoso, I., Saraiva, M.J. and Brito, R.M. (2001) Tetramer dissociation and monomer partial unfolding precedes protofibril formation in amyloidogenic transthyretin variants. The Journal of biological chemistry, 276, 27207-13.

Rambaran, R.N. and Serpell, L.C. (2008) Amyloid fibrils: Abnormal protein assembly. prion, 2, 112-117.

Reixach, N., Deechongkit, S., Jiang, X., Kelly, J.W. and Buxbaum, J.N. (2004) Tissue damage in the amyloidoses: Transthyretin monomers and nonnative oligomers are the major cytotoxic species in tissue culture. Proceedings of the National Academy of Sciences of the United States of America , $101,2817-2822$.

Robins y Cotran. (2007) Patología estructural y funcional. $7^{\circ}$ edición. Elsevier.

Roychaudhuri, R., Yang, M., Hoshi, M.M. and Teplow, D.B. (2009) Amyloid beta-protein assembly and Alzheimer disease. The Journal of biological chemistry, 284, 4749-53.

Ryan, R.O., Forte, T.M. and Oda, M.N. (2003) Optimized bacterial expression of human apolipoprotein A-I. Protein expression and purification, 27, 98-103.

Safi, W., Maiorano, J.N. and Davidson, W.S. (2001) A proteolytic method for distinguishing between lipid-free. J Lipid Res. 42(5):864-72.

Sandberg, A., Luheshi, L.M., Söllvander, S., et al. (2010) Stabilization of neurotoxic Alzheimer amyloidbeta oligomers by protein engineering. Proceedings of the National Academy of Sciences of the United States of America, 107, 15595-600.

Saraiva, M.J. (2001) Transthyretin amyloidosis: a tale of weak interactions. FEBS letters, 498, 201-3.

Segrest, J.P., Jones, M.K., Loof, H. De, Brouillette, C.G., Venkatachalapathi, Y.V. and Anantharamaiah, G.M. (1992) The amphipathic helix in the exchangeable apolipoproteins: a review of secondary structure and function. Journal of Lipid Research , 33, 141-166.

Shao, B., Cavigiolio, G., Brot, N., Oda, M.N. and Heinecke, J.W. (2008) Methionine oxidation impairs reverse cholesterol transport by apolipoprotein A-I. Proceedings of the National Academy of Sciences of the United States of America, 105, 12224-9.

Shi, C. and Pamer, E.G. (2011) Monocyte recruitment during infection and inflammation. Nature reviews. Immunology, 11, 762-74.

Suk, J.Y., Zhang, F., Balch, W.E., Linhardt, R.J. and Kelly, J.W. (2006) Heparin Accelerates Gelsolin Amyloidogenesis †. , 2234-2242.

Tricerri, M. a, Behling Agree, a K., Sanchez, S a, Bronski, J. and Jonas, a (2001) Arrangement of apolipoprotein A-I in reconstituted high-density lipoprotein disks: an alternative model based on fluorescence resonance energy transfer experiments. Biochemistry, 40, 5065-74.

Uversky, V.N. (2010) Mysterious oligomerization of the amyloidogenic proteins. The FEBS journal, 277, 2940-53. 
Westermark, P.P., Mucchiano, G.G., Marthin, T.T., Johnson, K.H.K.H. and Sletten, K.K. (1995) Apolipoprotein Al-derived amyloid in human aortic atherosclerotic plaques. Am J Pathol, 147, $1186-1192$.

Winrow, V.R., Winyard, P.G., Morris, C.J. and Blake, D.R. (1993) Free radicals in inflammation: second messengers and mediators of tissue destruction. British Medical Bulletin , 49 , 506-522.

Wong, Y.Q., Binger, K.J., Howlett, G.J. and Griffin, M.D.W. (2010) Methionine oxidation induces amyloid fibril formation by full-length apolipoprotein A-I. Proceedings of the National Academy of Sciences of the United States of America, 107, 1977-82.

Wright, H.L., Moots, R.J., Bucknall, R.C. and Edwards, S.W. (2010) Neutrophil function in inflammation and inflammatory diseases. Rheumatology (Oxford, England), 49, 1618-31.

Yamauchi, Y., Chang, C.C.Y., Hayashi, M., Abe-Dohmae, S., Reid, P.C., Chang, T.-Y. and Yokoyama, S. (2004) Intracellular cholesterol mobilization involved in the ABCA1/apolipoprotein-mediated assembly of high density lipoprotein in fibroblasts. Journal of Lipid Research , 45 , 1943-1951.

Zannis, V., Chroni, A. and Krieger, M. (2006) Role of apoA-I, ABCAI, LCAT, and SR-BI in the biogenesis of HDL. Journal of Molecular Medicine, 84, 276-294 LA - English.

Zhang, Wei, Wang, T., Pei, Z., et al. (2005) Aggregated a-synuclein activates microglia: a process leading to disease progression in Parkinson's disease. The FASEB Journal , 19, 533-542.

Zhao, H., Tuominen, E.K.J. and Kinnunen, P.K.J. (2004) Formation of amyloid fibers triggered by phosphatidylserine-containing membranes. Biochemistry, 43, 10302-7.

Zheng, L., Nukuna, B., Brennan, M., et al. (2004) Apolipoprotein A-l is a selective target for myeloperoxidase-catalyzed oxidation and functional impairment in subjects with cardiovascular disease. , 114, 529-541. 